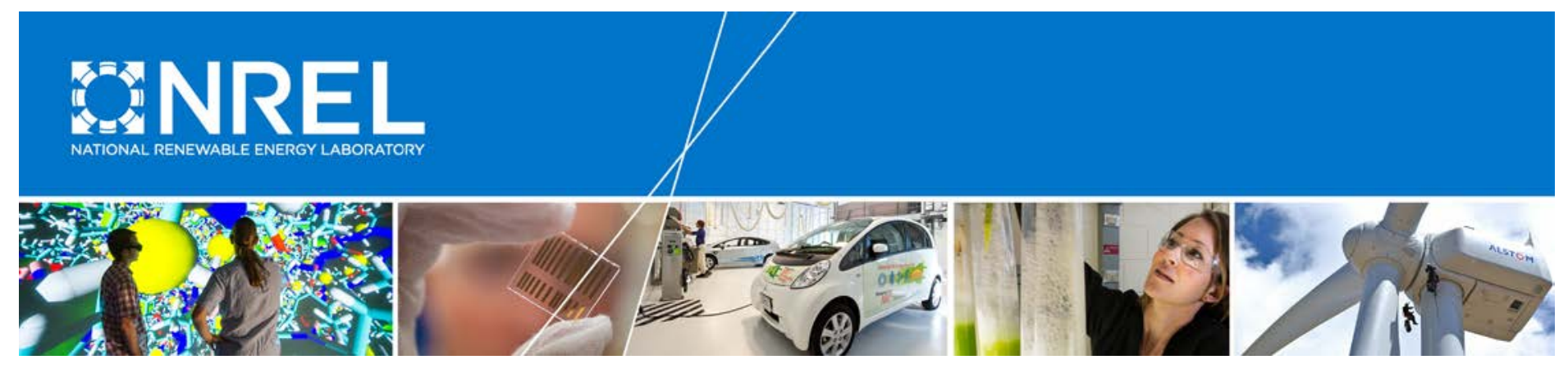

\title{
Sustainable Energy in Remote Indonesian Grids: Accelerating Project Development
}

B. Hirsch, K. Burman, C. Davidson, and $\mathrm{M}$. Elchinger National Renewable Energy Laboratory

R. Hardison, D. Karsiwulan, and B. Castermans Winrock International

Produced under direction of the U.S. Department of Energy by the National Renewable Energy Laboratory (NREL) under DE-FOA-0000620 - Accelerating the Deployment of Energy Efficiency and Renewable Energy in Indonesia (Task No. 6: Financing and Project Development) and Task No IGIN.6200.

NREL is a national laboratory of the U.S. Department of Energy Office of Energy Efficiency \& Renewable Energy Operated by the Alliance for Sustainable Energy, LLC

This report is available at no cost from the National Renewable Energy Laboratory (NREL) at www.nrel.gov/publications.

Strategic Partnership Project Report NREL/TP-7A40-64018

June 2015

Contract No. DE-AC36-08GO28308 


\section{Sustainable Energy in Remote Indonesian Grids: Accelerating Project Development}

B. Hirsch, K. Burman, C. Davidson, and $\mathrm{M}$. Elchinger

National Renewable Energy Laboratory

R. Hardison, D. Karsiwulan, and B. Castermans

Winrock International

Prepared under Task No. IGIN.6200
NREL is a national laboratory of the U.S. Department of Energy Office of Energy Efficiency \& Renewable Energy Operated by the Alliance for Sustainable Energy, LLC

This report is available at no cost from the National Renewable Energy Laboratory (NREL) at www.nrel.gov/publications.

\section{Strategic Partnership Project Report}

NREL/TP-7A40-64018

June 2015

Contract No. DE-AC36-08G028308
National Renewable Energy Laboratory 15013 Denver West Parkway

Golden, CO 80401

303-275-3000 • www.nrel.gov 


\section{NOTICE}

This manuscript has been authored by employees of the Alliance for Sustainable Energy, LLC ("Alliance") under Contract No. DE-AC36-08GO28308 with the U.S. Department of Energy ("DOE”).

This report was prepared as an account of work sponsored by an agency of the United States government. Neither the United States government nor any agency thereof, nor any of their employees, makes any warranty, express or implied, or assumes any legal liability or responsibility for the accuracy, completeness, or usefulness of any information, apparatus, product, or process disclosed, or represents that its use would not infringe privately owned rights. Reference herein to any specific commercial product, process, or service by trade name, trademark, manufacturer, or otherwise does not necessarily constitute or imply its endorsement, recommendation, or favoring by the United States government or any agency thereof. The views and opinions of authors expressed herein do not necessarily state or reflect those of the United States government or any agency thereof. 


\section{Acknowledgments}

NREL thanks Winrock International for its support and input on this project and report. NREL also would like to thank Perusahaan Listrik Negara (PLN) and the government agencies and individuals in Lamandau, Sabu Island, and Sumba Island for their insights and assistance during the Sustainable Energy in Remote Indonesian Grids (SERIG) team site visits and ongoing activities. 


\section{List of Abbreviations and Acronyms}

\begin{tabular}{|c|c|}
\hline $\mathrm{ADB}$ & Asian Development Bank \\
\hline CESC & Clean Energy Solutions Center \\
\hline $\mathrm{CO}_{2}$ & carbon dioxide \\
\hline COD & chemical oxygen demand \\
\hline $\mathrm{CPO}$ & crude palm oil \\
\hline DANIDA & Danish International Development Agency \\
\hline DOE & U.S. Department of Energy \\
\hline DSCR & debt service coverage ratio \\
\hline EFB & empty fruit bunch \\
\hline FFB & fresh fruit bunch \\
\hline FiT & feed-in tariff \\
\hline GHG & greenhouse gas \\
\hline GOI & Government of Indonesia \\
\hline HOMER & hybrid optimization for multiple energy resources \\
\hline IDR & Indonesian rupiah \\
\hline IPP & independent power producer \\
\hline IRR & internal rate of return \\
\hline $\mathrm{kW}$ & kilowatt \\
\hline $\mathrm{kWh}$ & kilowatt-hour \\
\hline LCOE & levelized cost of energy \\
\hline LED & light-emitting diode \\
\hline MW & megawatt \\
\hline MWe & megawatt electric \\
\hline NAL & Nirmala Agro Lestari \\
\hline NGOs & non-governmental organizations \\
\hline NPV & net present value \\
\hline NREL & National Renewable Energy Laboratory \\
\hline NTT & Nusa Tenggara Timor (East Nusa Tengarra province) \\
\hline O\&M & operations and maintenance \\
\hline $\mathrm{ORC}$ & organic rankine cycle \\
\hline PLN & Perusahaan Listrik Negara \\
\hline PLTD & Pusat Listrik Tenaga Diesel (diesel power center, Indonesia) \\
\hline POME & palm oil mill effluent \\
\hline PPA & power purchase agreement \\
\hline PT & Perseroan Terbatas (limited company) \\
\hline PT NAL & PT Nirmala Agro Lestari \\
\hline PV & photovoltaics \\
\hline $\mathrm{RE}$ & renewable energy \\
\hline RUPTL & Rencana Usaha Penyediaan Tenaga Listrick \\
\hline SAM & System Advisor Model \\
\hline SERIG & Sustainable Energy for Remote Indonesian Grids \\
\hline SFC & specific fuel consumption \\
\hline SII & Sumba Iconic Island \\
\hline SSE & surface solar energy \\
\hline VGF & viability gap financing \\
\hline
\end{tabular}




\section{Executive Summary}

Sustainable Energy for Remote Indonesian Grids (SERIG) is a U.S. Department of Energy (DOE) funded initiative to support Indonesia's efforts to develop clean energy and increase access to electricity in remote locations throughout the country. With DOE support, the SERIG implementation team consists of the National Renewable Energy Laboratory (NREL) and Winrock International's Jakarta, Indonesia office. Through technical assistance that includes techno-economic feasibility evaluation for selected projects, government-to-government coordination, infrastructure assessment, stakeholder outreach, and policy analysis, SERIG seeks to provide opportunities for individual project development and a collective framework for national replication.

Lamandau District of Central Kalimantan, along with Sabu and Sumba Islands of East Nusa Tenggara province, were selected as SERIG pilot project locations. All three locations have high electricity generation costs, high poverty rates, diesel dependencies, relatively low electrification ratios, reasonable site access, excellent renewable energy (RE) potential, substantial load growth (10\% to $20 \%$ annually), and broad support for RE development from multiple stakeholders including the Indonesia national electric utility Perusahaan Listrik Negara (PLN), regional governments, nongovernmental organizations, and others.

The techno-economic feasibility analyses performed to date identify an optimum hybrid technology mix for each project given available data such as loads and load growth, locally available renewable resources, and existing diesel genset configuration. This report takes the techno-economic analyses one step further by feeding these outputs into conventional assessments of financial return that would typically be conducted by private investors. Small individual projects often do not receive this level of detailed evaluation by private investors because such assessments are data- and timeintensive, and hence, costly. This report is an attempt to reduce these and associated start-up and transaction costs in order to accelerate the development process, by defining optimum investment prospects in terms of size and type of project. Along with financial analysis, the SERIG team aims to facilitate project development through stakeholder outreach and institutional cooperation, i.e., bring appropriate entities and information together to identify opportunities and unmet needs.

HOMER analysis for Lamandau and Sabu Island resulted in a least-cost system configuration based on life-cycle costs that included existing diesel gensets, site-appropriate RE technologies, hourly dispatch simulation for the entire year, and associated costs.

According to the analysis, the lowest life-cycle cost system in Lamandau is a diesel-biogas hybrid system combining two separate biogas generation projects using palm oil mill effluent (POME), together totaling 3.5 megawatt electric (MWe), which would displace almost all of the current diesel generation. Extension of power lines approximately $14 \mathrm{~km}$ would be necessary to connect these POME generation projects to the existing power grid and increase the electrification ratio. A feed-in tariff (FiT) of $\$ 0.1138$ per kilowatt-hour (kWh) was used for the analysis.

On Sabu Island, two different system configurations were modeled: 350 kilowatt of photovoltaics (PV) with no batteries, and $1 \mathrm{MW}$ of PV with $461 \mathrm{kWh}$ of lead acid battery storage. The $350 \mathrm{~kW}$ PV system would be expected to provide about $13 \%$ of the annual electricity production while the $1 \mathrm{MW}$ PV and battery system would provide about $35 \%$ of total production. The FiT for PV on Sabu was 
estimated at $\$ 0.20 / \mathrm{kWh}$ for the $350 \mathrm{~kW}$ PV system with no batteries and $\$ 0.25 / \mathrm{kWh}$ for the $1 \mathrm{MW}$ PV system with battery storage.

On Sumba Island, the SERIG team is focusing its efforts on a grid integration study to maximize diesel fuel displacement from a $660 \mathrm{~kW}$ wind turbine and flywheel hybrid system. This demonstration project, scheduled for completion by the end of 2015, will be part of a much larger high contribution RE effort across all of Sumba, called the Sumba Iconic Island (SII) initiative, which will potentially include more wind, hydropower, biogas, and PV. Numerous other institutions and organizations are involved in the SII initiative, including the Asian Development Bank, the Danish International Development Agency, Hivos, Perseroan Terbatas (PT) Sewatama, and Winrock International. A target FiT of approximately 2,750 Indonesian rupiah (IDR) per $\mathrm{kWh}(\$ 0.25 / \mathrm{kWh})$ for the wind project has been identified by the private developer to meet its investment criteria.

A more detailed financial evaluation was conducted on the Lamandau and Sabu Island proposed RE projects based on the outputs of the HOMER modeling to determine the attractiveness of these projects to private investors. Several assumptions and sensitivity analyses were included in the assessment, which developed pro forma financial statements to determine cash flows and potential financial returns to investors. Based on site- and project-specific capital costs, levelized cost of energy (LCOE), and FiT, the analyses yielded an internal rate of return (IRR) and net present value (NPV) for each project. Table ES-1 summarizes these calculations for the base case for all three projects. For the two different PV system configurations on Sabu Island, a viability gap financing calculation was also conducted to determine the amount of outside funding, i.e., capital cost buydown that would be necessary to yield a 14\% IRR that was assumed to be the targeted margin for a private investor in this region. The POME biogas project on Lamandau does not require viability gap financing (VGF) because it is already a highly attractive investment opportunity.

Table ES-1: Financial Analysis Summary of Three Projects with Base Case Assumptions

\begin{tabular}{|c|c|c|c|c|c|c|}
\hline $\begin{array}{c}\text { Proposed Location } \\
\text { and System }\end{array}$ & $\begin{array}{c}\text { FiT } \\
(\$ / \mathrm{kWh})\end{array}$ & NPV & $\begin{array}{l}\text { IRR } \\
\text { (base } \\
\text { case) }\end{array}$ & $\begin{array}{l}\text { Capital } \\
\text { Cost }\end{array}$ & $\begin{array}{c}\text { LCOE } \\
(\$ / \mathrm{kWh})\end{array}$ & $\begin{array}{l}\text { VGF for } \\
14 \% \text { IRR }\end{array}$ \\
\hline $\begin{array}{l}\text { Lamandau - POME } \\
\text { biogas, } 3.5 \mathrm{MWe}\end{array}$ & $\$ 0.1138$ & $\$ 2.021 \mathrm{M}$ & $50.2 \%$ & $\$ 8.78 \mathrm{M}$ & $\$ 0.0106$ & ---- \\
\hline $\begin{array}{l}\text { Sabu - } 350 \text { kW, no } \\
\text { batteries }\end{array}$ & $\$ 0.20$ & $(\$ 585,000)$ & $-3.0 \%$ & $\$ 1.575 \mathrm{M}$ & $\$ 0.3097$ & $\$ 687,000$ \\
\hline $\begin{array}{l}\text { Sabu }-1,000 \mathrm{~kW} \text {, } \\
\text { with } 461 \mathrm{kWh} \\
\text { batteries }\end{array}$ & $\$ 0.25$ & (\$1.5M) & $0.2 \%$ & $\$ 4.77 M$ & $\$ 0.3047$ & $\$ 1.489 \mathrm{M}$ \\
\hline
\end{tabular}

Table ES-1 focuses on the financial returns from an independent power producer (IPP) perspective. Alternatively, PLN could choose to develop a project like this instead of adding new diesel capacity to meet growing demand. Compared to a generation cost of $\$ 0.39 / \mathrm{kWh}$ for new diesel, PLN would realize an NPV of $\$ 475,000$ by instead developing the PV on Sabu.

Sensitivity analysis conducted on these three projects demonstrated that capacity factor and cost of the original installation (represented by $\$ /$ Watt installed) were the two variables that impacted the 
attractiveness of these potential investments the most. This points to the need for detailed grid stability and integration studies, especially for high contribution RE-diesel hybrid systems, to achieve maximum technical and financial performance and displace as much diesel fuel as forecasted in the simulations.

The financial analysis also highlights different perspectives that may be required for ultimately successful development of each of these projects. Specifically, Lamandau is shown to be potentially highly profitable and hence, no outside incentives would be required for private investment in this proposed project. Photovoltaic generation with or without batteries on Sabu island, however, is shown to be much less attractive but still would cost-effectively displace some diesel generation with proper integration into the local PLN grid. Hence, VGF may be required if a private developer were to invest in Sabu, or perhaps PLN may choose to develop the project as it still represents cost savings compared to diesel generation. ${ }^{*}$ In other circumstances, such as on Sumba Island, it is expected that a combination of public and private financing and project developers will all contribute to a diverse generation mix and ownership structure. Broadly, site- and community-specific project sustainability strategies will be required for long-term success for all of these projects. This includes a business plan, an ownership structure, payment mechanism, an identified "project champion" and viable business entity to conduct ongoing operations, maintenance, troubleshooting, bill collection, and community education and outreach.

These analyses and project-specific recommendations are being conducted under existing conditions, specifically incentives and policies that are now in place. Current trends such as global fossil fuel price declines, combined with reduction in fossil fuel price subsidies in Indonesia, will likely impact financial viability and projections of specific projects, along with distribution of benefits and costs. The next and final SERIG report will aim to address these issues and examine incentives, policies, and lessons learned from the selected SERIG projects and other locations to leverage opportunities and offer national replication strategies for broader, accelerated deployment and impact.

\footnotetext{
* As explained in more detail in the main report, because there are different discount rates for NPV and IRR calculations, it is possible to have a negative NPV but still achieve cost savings, especially from the utility perspective, because cost savings are derived from reduction in diesel fuel usage. Viability gap financing addresses the lack of investment income on a project that may achieve fuel, and hence cost savings, but does not yield a return relative to the original capital investment, opportunity cost, and prevailing discount rate.
} 


\section{Table of Contents}

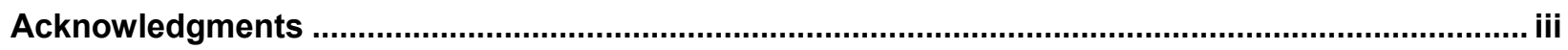

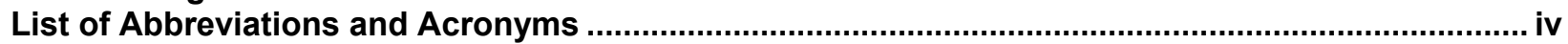

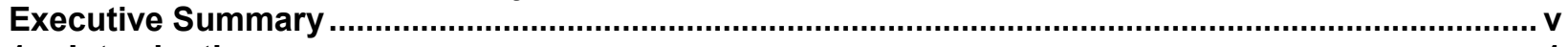

1 Introduction

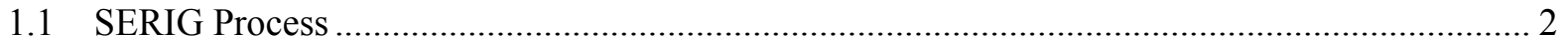

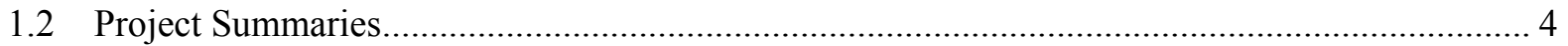

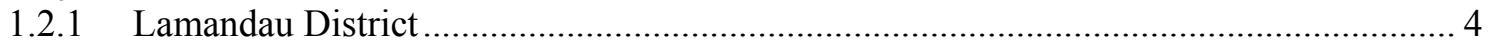

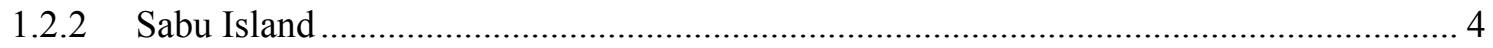

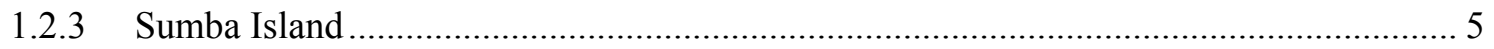

1.3 Institutional Context for Renewable Energy in Remote Grids.................................................... 5

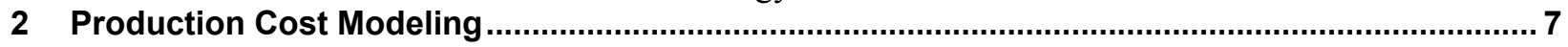

2.1 Assumptions for Electricity Rate Structure and Cost ............................................................ 7

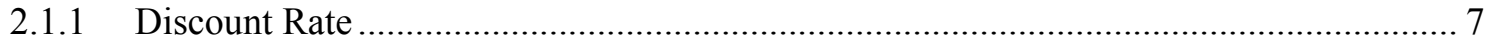

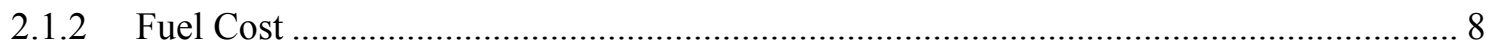

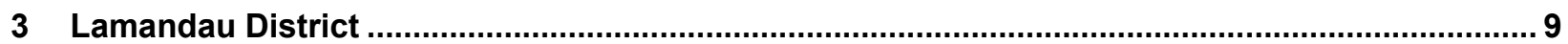

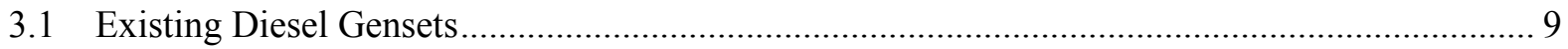

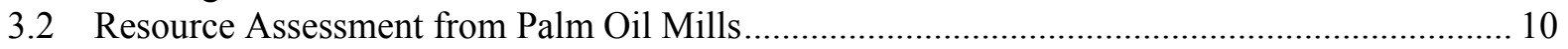

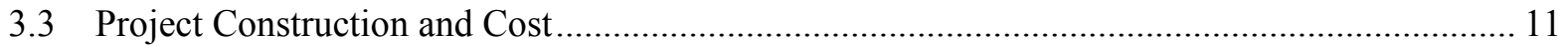

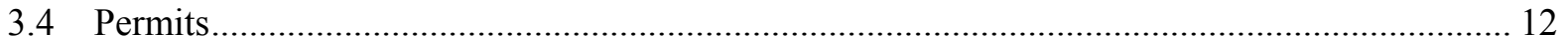

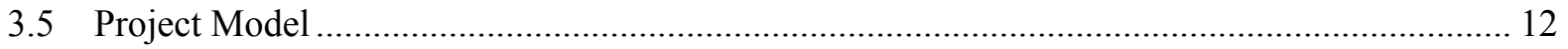

3.6 Production Cost Modeling Results for Lamandau ................................................................. 12

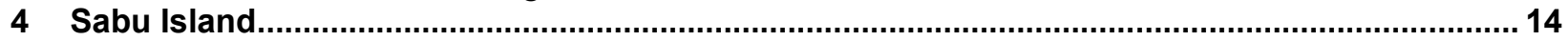

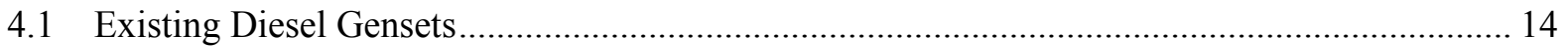

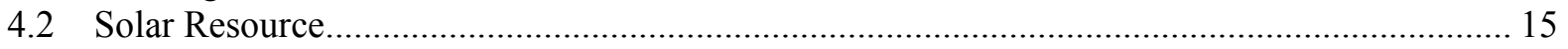

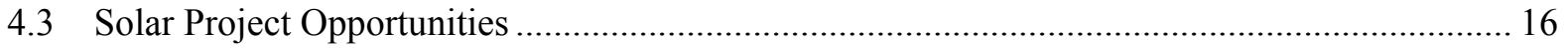

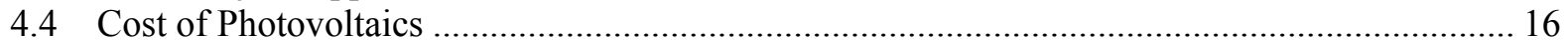

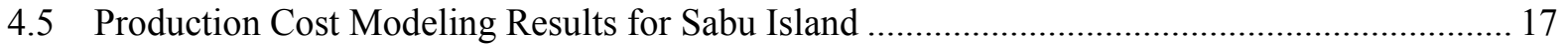

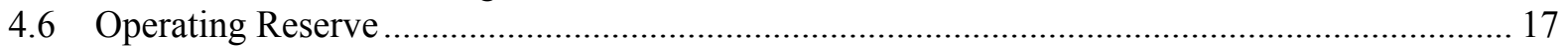

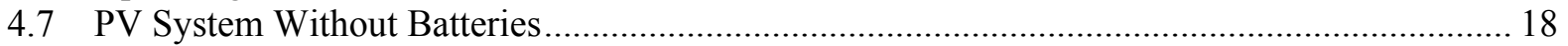

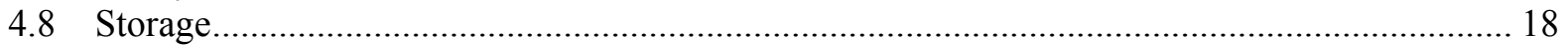

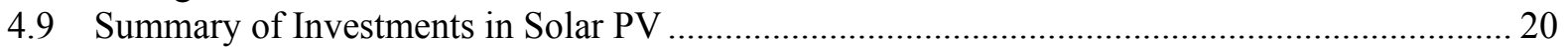

4.10 Integration Services: Storage and Balance of System Management ....................................... 21

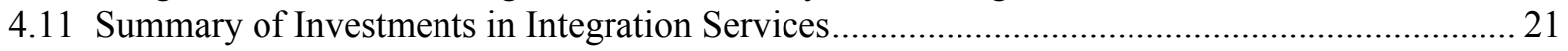

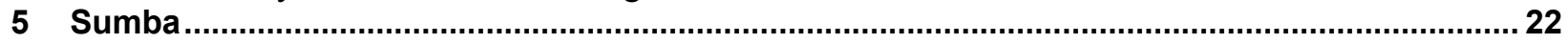

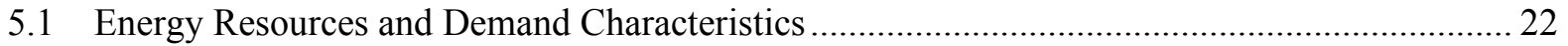

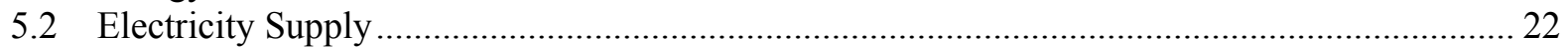

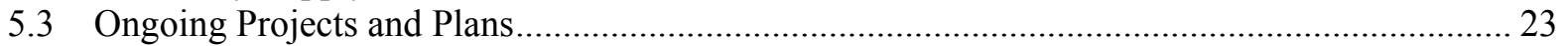

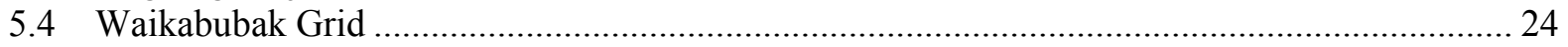

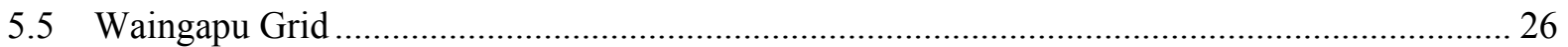

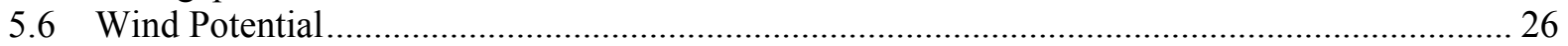

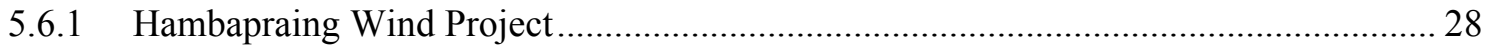

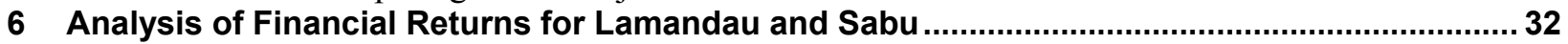

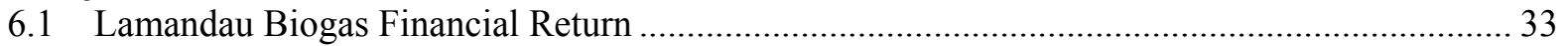

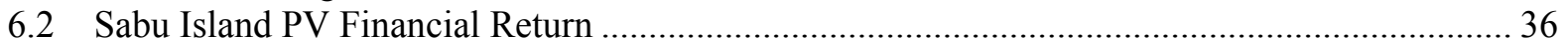

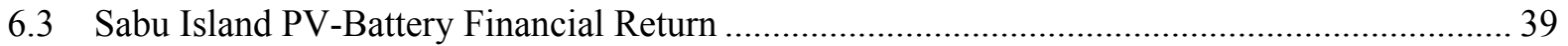

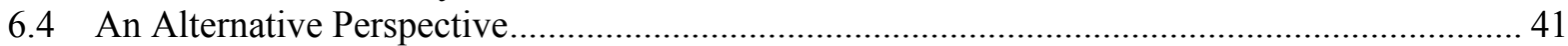

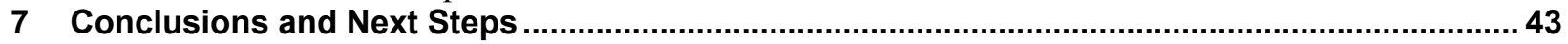

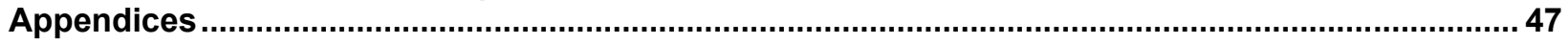

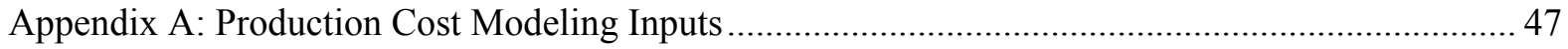

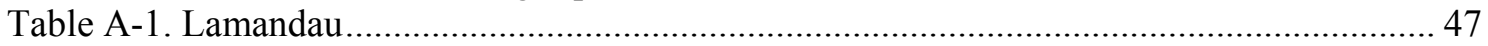

viii 
Table A-2.Sabu.

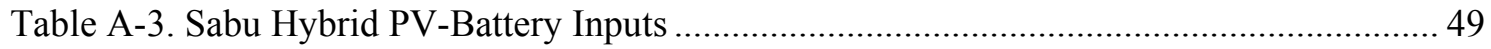

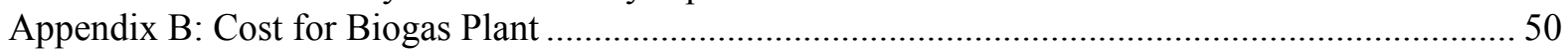

Appendix C: Detailed Sumba Wind Characteristics at Hambapraing .............................................. 51

Table C-1. Measurement Results (2012) for Hambapraing, Sumba Island............................... 51

Table C-2. Measurement Results (2013) for Hambapraing, Sumba Island..................................51

Table C-3. Measurement Results (2014) for Hambapraing, Sumba Island................................5 52

Table C-4. Wind Rose and Wind Speed Distribution (July 1, 2012 - November 1, 2014) for

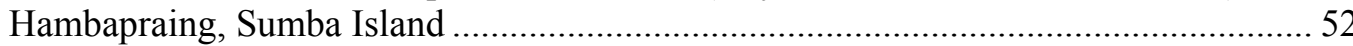

Figure C-1. Wind speed distribution (October 1, 2012 - November 1 2014) for Hambapraing,

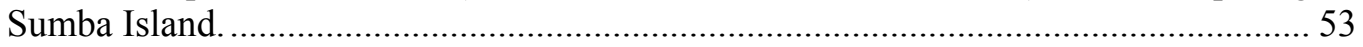

Appendix D: Pro Forma ....................................................................................................... 54

Appendix E: Renewable Energy Opportunities for Remote Indonesian Grids, Jakarta Workshop ..... 58

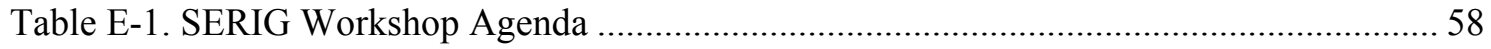

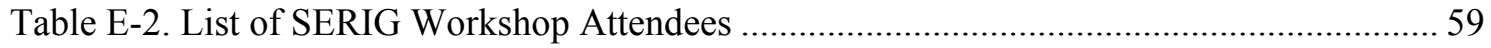

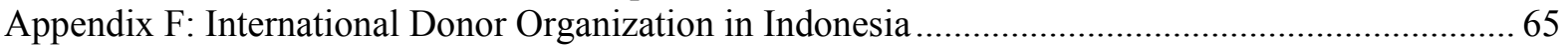




\section{List of Figures}

Figure 1. Location of pilot project sites: Lamandau District (Central Kalimantan), Sabu Island and

Sumba Island (East Nusa Tengarra).

Figure 2. October 2014 Stakeholder Workshop - Jakarta. ........................................................... 4

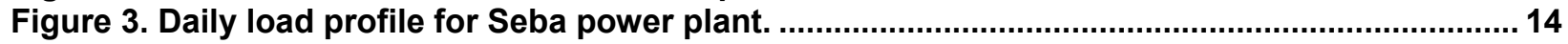

Figure 4. Map of Sabu Island with solar - resources....................................................................... 16

Figure 5. Sensitivity analysis on PV installed cost $(\$ / W)$ and diesel escalation price. .................... 17

Figure 6. Monthly average electric production......................................................................... 19

Figure 7. Recommended PV array capacity across the range of projected loads........................... 20

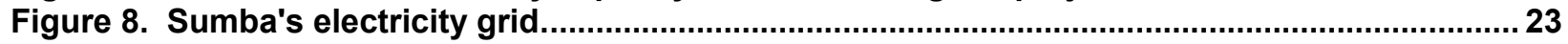

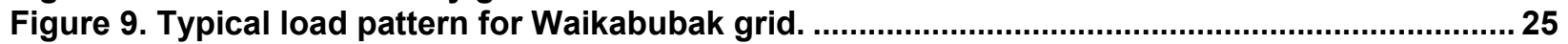

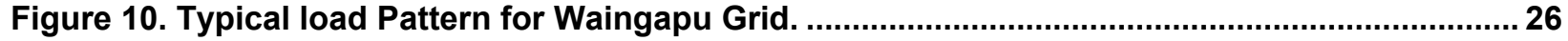

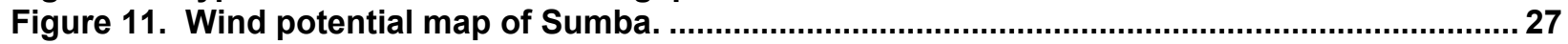

Figure 12. The Hambapraing site and surrounding area.......................................................... 29

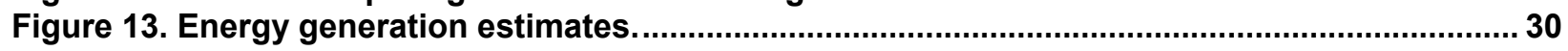

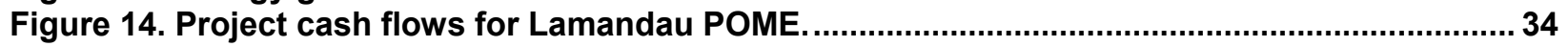

Figure 15. NPV sensitivity to discount rates for Lamandau POME. .................................................... 35

Figure 16. Tornado chart of selected inputs for Lamandau POME. .................................................... 35

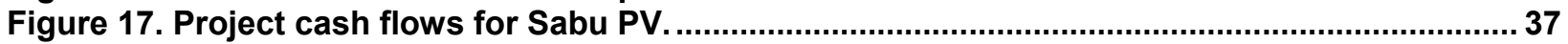

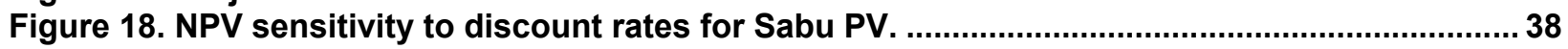

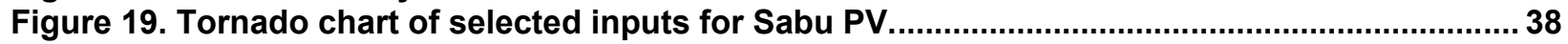

Figure 20. Project Cash Flows for Sabu Hybrid PV-Battery ..................................................... 40

Figure 21. NPV sensitivity to discount rates for Sabu hybrid PV-battery.........................................40

Figure 22. Tornado chart of selected inputs for Sabu hybrid PV-battery......................................... 41

Figure 23. Sensitivity of NPV to PPA price for Sabu PV. .......................................................... 42

\section{List of Tables}

Table 1. Diesel Power Plant and Capacities in Lamandau District (Feb. 2014) ................................. 9

Table 2. Summary of Load Data from Model.............................................................................. 10

Table 3. Palm Oil Companies and Total Energy Potential from POME and Biomass Waste ............ 11

Table 4. Distance and Cost to Interconnect with Palm Oil Mills ................................................... 12

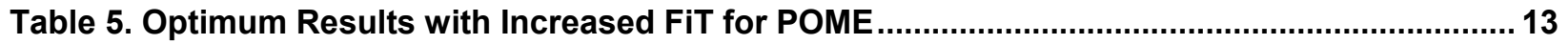

Table 6. Summary of Load Data from Production Cost Model........................................................ 14

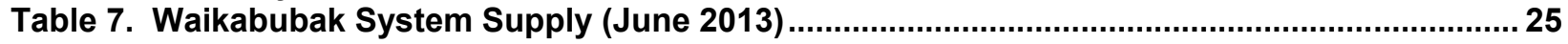

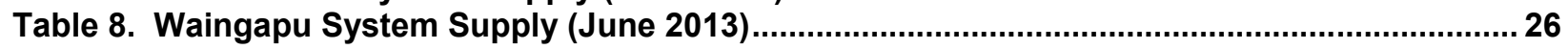

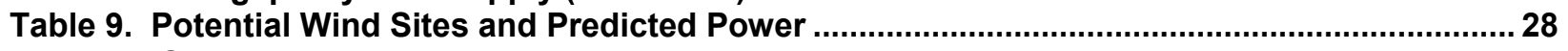

Table 10. Summary Measurement Results (July 1, 2012 - November 1, 2014) .............................. 30

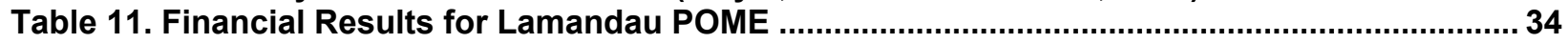

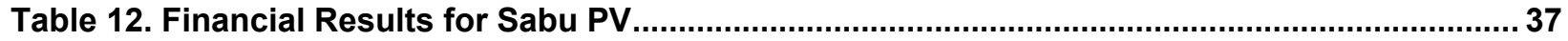

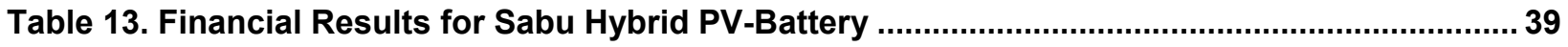

Table 14. Financial Analysis Summary of Three Projects with Base Case Assumptions................. 44 


\section{Introduction}

Sustainable Energy for Remote Indonesian Grids (SERIG) is a U.S. Department of Energy (DOE) funded initiative to support Indonesia's efforts to develop clean energy and increase access to electricity in remote locations throughout the country. With DOE support, the SERIG implementation team consists of the National Renewable Energy Laboratory (NREL) and Winrock International's Jakarta, Indonesia office. Through technical assistance that includes techno-economic feasibility evaluation for selected projects, government-to-government coordination, infrastructure assessment, stakeholder outreach, and policy analysis, SERIG seeks to provide opportunities for individual project development and a collective framework for national replication.

Lamandau District of Central Kalimantan, along with Sabu and Sumba Islands of East Nusa Tenggara province (Nusa Tenggara Timur (NTT)), were selected as SERIG pilot project locations. This entailed a rigorous evaluation and selection process that included site visits, stakeholder consultation, data collection and analysis, and development of other metrics and ranking criteria. All three locations have high electricity generation costs, high poverty rates, diesel dependencies, relatively low electrification ratios, reasonable site access, excellent renewable energy (RE) potential, and strong support for RE development from multiple stakeholders including Indonesia's national electric utility Perusahaan Listrik Negara (PLN), the regional governments, nongovernmental organizations (NGO), and others. Figure 1 identifies the locations of the three selected sites within Indonesia.

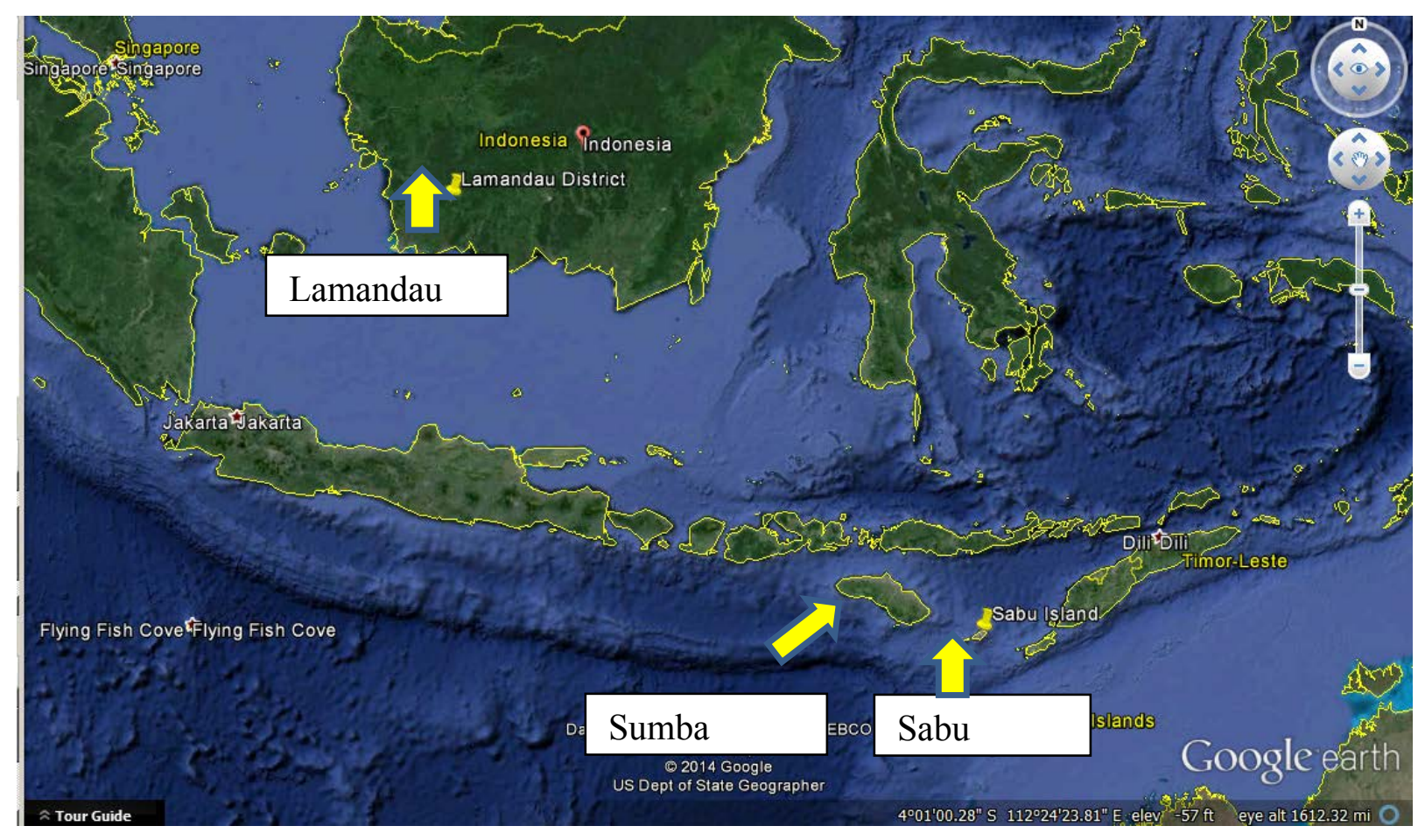

Figure 1. Location of pilot project sites: Lamandau District (Central Kalimantan), Sabu Island and Sumba Island (East Nusa Tengarra).

Source: Google Earth 
The selection and analysis process for Lamandau and Sabu Island were similar in that a detailed techno-economic feasibility study was conducted using hybrid optimization for multiple energy resources (HOMER) modeling software with site-specific data collection and input. Outputs of the HOMER modeling effort resulted in a least-cost system configuration that included the existing diesel gensets, site-appropriate RE technologies, hourly dispatch simulation for the entire year, and associated costs; all are explained in more detail below.

The SERIG team also conducted an energy efficiency analysis in both locations (Lamandau and $\mathrm{Sabu}$ ) that identified specific end user efficiencies and supply-side generator efficiency improvements as potentially cost-effective opportunities for diesel fuel savings. Considering that both locations are electricity supply constrained, i.e., there is more demand for electricity than can be provided by existing supply, any improvements in energy efficiency will result in more electricity available for the unmet demand. This will support an increase in the electrification ratio in these locations, which is a national goal for PLN.

Sumba Island was also selected to receive technical assistance under the SERIG analysis and project development effort, though the dynamics of the situation required a different approach. Several techno-economic studies and related analyses, including long-term, site-specific wind energy resource availability and data collection, had already been conducted prior to SERIG involvement. Winrock International, as well as other organizations such as the Asian Development Bank (ADB), Castlerock Consulting, the Danish International Development Agency (DANIDA), and Hivos, a Dutch development NGO, has been very active in Sumba. Thus, a high contribution RE-diesel hybrid system development opportunity is evolving rapidly, which requires more detailed grid stabilization and integration considerations to address the preferred hardware option, currently a wind turbine and possibly a flywheel. The SERIG team is now focusing its efforts in Sumba by assisting with these grid integration issues.

\subsection{SERIG Process}

We have applied multiple analytic tools to specific projects to provide a "business case" rationale that aims to accelerate project development. Broadly, SERIG employs both a bottom-up approach to individual projects via site-specific and detailed techno-economic evaluation and a top-down approach through policy analysis and government-to-government engagement of best practices.

The bottom-up approach focuses on pre- and early feasibility analysis to reduce risk for private investors to fully develop the projects. This provides win-win opportunities for private industry, local communities, and the Indonesian and United States governments regarding greenhouse gas (GHG) emissions reductions, clean energy development, and increasing electrification ratios. At a minimum, individual projects provide direct benefits to various stakeholders, but ideally, these individual projects can be aggregated and consolidated to expand those benefits, while also providing a framework and lessons learned for streamlining and accelerating the deployment of clean energy projects more broadly.

The top-down approach is based on establishing successful pilot projects that bolster confidence and investment from financial institutions and the private sector; enhance technical capacity at the utility and local level; and improve supply chains so appropriate technology, such as LED lighting and advanced inverters, is available and supported throughout the country. National and regional policies that encourage a stable investment environment and account for the unique challenges posed by 
remote, island power systems across Indonesia are also essential components of a top-down approach to facilitate clean energy development.

Significant data collection and several studies have preceded this document within the SERIG framework. These include the following: ${ }^{2}$

- Sustainable Energy Integration in Remote Grids: Challenges and Opportunities

- Sustainable Energy in Isolated Grids in Indonesia: Renewable Energy and Energy Efficiency Policy Overview

- Finance Challenges and Opportunities: Sustainable Energy in Isolated Grids in Indonesia

- Sustainable Energy in Isolated Grids in Indonesia: Deployment of Energy Efficiency Technologies - Barriers and Opportunities

- Sustainable Energy in Remote Indonesian Grids: Feasibility Study for Integrating Renewable Energy Technologies

This is the second-to-last report in the series and focuses on the site-specific details of individual projects - primarily taking a bottom-up approach. The aim is to reduce risk and the up-front costs that are often barriers to initiating small, singular projects, and lay the groundwork for broader mobilization.

The next report, which will apply a top-down approach and be the last under the existing SERIG structure, will incorporate lessons learned from the individual projects and broader experience from other locations around the world to provide a national replication strategy to scale-up clean energy development throughout Indonesia. It is scheduled for completion in the second quarter of 2015.

Another essential component of SERIG has been stakeholder outreach and public education. This has been accomplished partially through distribution of the documents described here, but also via public meetings, stakeholder workshops, sponsored trainings, government-to-government vehicles, and other targeted activities. One example of this is the public workshop, "Renewable Energy Opportunities for Remote Indonesian Grids," sponsored by DOE and the SERIG team, held in Jakarta on October 1, 2014. The agenda and attendee list from this workshop can be found in Appendix F.

The presentations from the workshop can be viewed at the Clean Energy Solutions Center (CESC) website. ${ }^{3}$ CESC is part of the Clean Energy Ministerial, initiated by DOE, "a global forum to share best practices and promote policies and programs that encourage and facilitate the transition to a global clean energy economy." 4 There were over 70 attendees and participants at the workshop, representing all aspects of the project development process, including government agencies, electric utilities, project developers, technology providers, financiers, NGOs, community leaders, and others.

\footnotetext{
${ }^{2}$ These studies have not been published. Please contact the authors of this report if you are interested in obtaining these..

${ }^{3}$ https://cleanenergysolutions.org/news/serig.

4 www.cleanenergyministerial.org.
} 


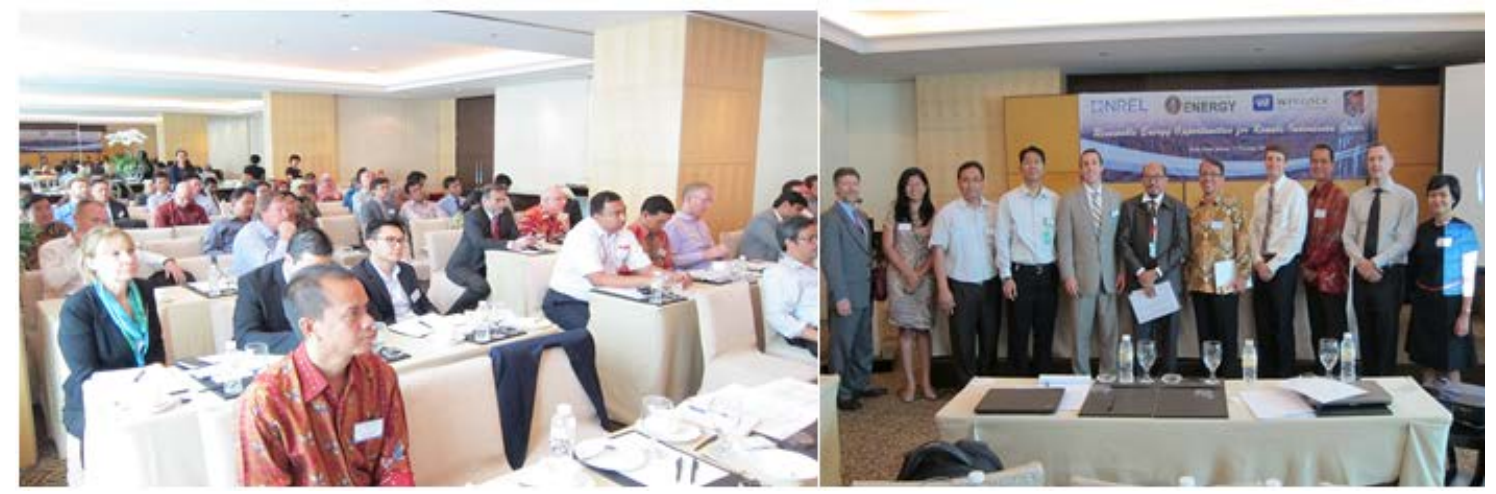

Figure 2. October 2014 Stakeholder Workshop - Jakarta.

Photo Credit: Winrock International

One last activity of note embodied in the SERIG approach is working closely with communities and local governments. In Sabu, for example, the SERIG team has met several times with the local government and various Ministries, provided a large, island-wide map of various land uses that remains helpful for ongoing planning and coordination activities, and has assisted in data collection and coordination between regional and national offices of PLN. To facilitate further coordination and project development, the head of the local government, the Bupati, has written a letter of support ${ }^{5}$ for the SERIG team that identifies specific activities and roles and responsibilities of the different parties.

\subsection{Project Summaries}

Drawing from data and analysis presented in previous reports, here we briefly review the selected sites to provide necessary background for the next sections, which offers a more detailed examination relevant for targeted financing and project development. Additional information on site selection and characteristics was included in the previous report, entitled Sustainable Energy in Remote Indonesian Grids: Feasibility Study for Integrating Renewable Energy Technologies.

\subsubsection{Lamandau District}

Lamandau, located in the province of Central Kalimantan, has an electrification ratio of roughly $36 \%$. The grid serves a primarily residential base load of 1,700 kilowatt $(\mathrm{kW})$ during the day and a peak load of $2,400 \mathrm{~kW}$ in the evening. Currently, PLN relies on six diesel generators (four rented and two owned) to meet the load. Economic analysis illustrates that adding 3.5 megawatt (MW) of electricity generated from palm oil mill effluent (POME) biogas has the potential to reduce the levelized cost of energy (LCOE) from an estimated $\$ 0.31 / \mathrm{kWh}$ to $\$ 0.11 / \mathrm{kWh}$. Solar PV could provide substantial diesel fuel savings, as well, though generation is less coincident with the nighttime load on the island.

\subsubsection{Sabu Island}

Sabu Island, in NTT, has an average daily load of $580 \mathrm{~kW}$ and a peak load of approximately 900 $\mathrm{kW}$. Currently, PLN relies on eight small diesel generators-all owned by PLN, though at the time of

\footnotetext{
${ }^{5}$ The letter of support can be shared with interested parties by contacting the authors of this report.
} 
the SERIG site visit, three were in disrepair. From the perspective of the utility, solar photovoltaics (PV) combined with battery storage provides an opportunity for reduction in diesel fuel use and modest LCOE reductions on Sabu Island (from an estimated $\$ 0.38 / \mathrm{kWh}$ to $\$ 0.35 / \mathrm{kWh}$ ). Economic analysis identified that integrating batteries with a $1 \mathrm{MW}$ solar installation would provide substantial fuel reduction while reducing the challenges associated with integrating and managing a large variable resource (solar) relative to the total load.

\subsubsection{Sumba Island}

Sumba Island, also in NTT province, was the third selected location to receive technical assistance under the SERIG analysis and project development effort. There are two separate grids on Sumba Island with a combined daytime peak load of 5.9 MW and an evening peak of 9.3 MW. The electrification ratio for the entire island is estimated at about $25 \%$. There are various RE opportunities on Sumba, including wind, hydro, and PV. There are also several other entities involved in clean energy development on the island, namely under the Sumba Iconic Island (SII) initiative, which has established a goal of $95 \%$ electrification and $100 \% \mathrm{RE}$ generation to meet the entire island's load by 2025.

\subsection{Institutional Context for Renewable Energy in Remote Grids}

Due to abundant natural resources and strong policy support, the Indonesian context is considered amenable to RE. The Government of Indonesia (GOI) has stated its desire to gradually remove energy market distorting subsidies, promote the use and development of RE, encourage public adoption of energy efficiency, spur the use of clean and efficient energy in the industrial and commercial sectors, and restructure the price of various energy sources. However, the majority of the implemented policies apply to grid-tied projects. The feed-in-tariff (FiT), available to private energy developers, is the exception, and provides the key incentive applicable to RE projects developed in isolated grids. The FiT sets a ceiling price of $\$ 0.25 / \mathrm{kWh}$ for PV projects, and 1,050 Indonesian rupiah (IDR) per kilowatt-hour $(\mathrm{kWh})(\$ 0.094 / \mathrm{kWh})$ for biogas projects plus a regional multiplier depending on the location of the project. The wind FiT is currently under review and is expected to be between 1,250 and $1,810 \mathrm{IDR} / \mathrm{kWh}(\$ 0.1136 / \mathrm{kWh}-\$ 0.1645 / \mathrm{kWh})$. There are also regional multipliers for the FiT, which reflect the different costs of energy and general business transactions in more remote parts of Indonesia. Further, provincial and district governments are required to develop an energy plan that is aligned with the national energy plan-though not all provinces have actually developed this (central Kalimantan has made significant progress, while NTT has not yet developed one). These policies have the potential to increase the economic attractiveness of a RE project and align PLN support for project development.

The key players directly involved with the generation or supply of electricity to businesses and households in Indonesia include PLN, independent power producers (IPP), individual communities, and captive power producers. Financing requires that a project meet financiers' return requirements and risk profile, as well as other relevant criteria-which will vary depending on the financier. Potential financiers or project developers for the projects analyzed by SERIG include PLN, the Ministry of Energy, local government, development banks such as the World Bank and the ADB, foreign government organizations such as the U.S. Millennium Challenge Corporation, DANIDA, and other donor countries, private sector banks, and NGOs. 
This report considers the projects identified in the previous technical feasibility study for each site, reviewing and elaborating the production cost modeling with new data, calculating the financial projections, and determining the risks around these financial projections. As well, this analysis will assess economic viability of projects and consider various financing mechanisms. 


\section{Production Cost Modeling}

This section reviews the production cost modeling for Lamandau District and Sabu Island. ${ }^{6}$ The analyses presented in this section look at these projects primarily from the perspective of the electric utility. A later section uses these production cost modeling outputs for financial analyses that might be performed by project developers and IPPs to ultimately make investment decisions.

Renewable energy generally requires a large capital investment compared with standard fossil-fuel generators. However, RE technology typically has low to no fuel cost and requires very little maintenance. Production cost modeling is the process of allocating the required load demand between the available generation units so that the cost of operation is minimized. This economic analysis compares the LCOE of the existing power production (base case) with the LCOE of a system with RE added into the generation mix. The preliminary analysis was conducted by NREL and Winrock using the HOMER modeling software. The results of the analysis are intended to assist PLN and IPPs in identifying the conditions under which solar PV, biogas, and wind turbines become cost effective for Lamandau District and Sabu Island.

Production cost modeling relies on several key modeling assumptions, namely, the interest rate and the fuel cost.

\subsection{Assumptions for Electricity Rate Structure and Cost}

Perusahaan Listrik Negara deploys uniform, tiered electricity rates for all regions of the country. Household tariffs are categorized as R1, R2, and R3, depending on the customer's electric demand and consumption. Remote grids primarily use diesel to generate electricity. Other electricity generation might use combined, locally available resources to produce electricity and thus have lower generation cost. High cost for diesel fuel and its transportation to remote areas make actual generation costs significantly higher than the national pricing structure, which is generally based on the less remote and lower cost regions of the country. Thus, the electricity price to the consumer does not truly reflect the cost of electricity production in remote areas. Perusahaan Listrik Negara's generation cost for such remote grids is between $\$ 0.30 / \mathrm{kWh}$ and $\$ 0.80 / \mathrm{kWh}$ depending on the location and other site-specific variables. ${ }^{7}$ Losses currently sustained by PLN for electricity delivered to remote grids is covered by subsidy payments from the national government budget. Renewable energy systems that produce power at a lower price than diesel generation in remote Indonesian grids have the potential to save PLN money by displacing diesel fuel.

\subsubsection{Discount Rate}

The discount rate is a critical parameter that depends on a number of factors. The HOMER models use a real discount rate, which is equal to the nominal or quoted rate minus the expected inflation rate over the life of the project. The real interest rate used in the HOMER models for this study is $8 \%$. Note that for IDR loans the nominal interest rate can be as high as $11 \%$ to $13 \%$. The increased interest rate disadvantages RE projects, which have high up-front capital costs and generally low

\footnotetext{
6 Production cost modeling was not performed for Sumba because it is not considered a potential candidate until after primary site visit and data collection efforts are complete and Sumba is further along in the development process.

${ }^{7}$ Information gathered on the site visit and speaking with PLN, February 2014.
} 
operations and maintenance (O\&M) costs. Conventional (diesel) generation is not impacted as much by high interest rates because the up-front financing is much less, though diesel generation is subject to fuel price escalation and volatility. In this case, $8 \%$ is considered a "conservative" number with respect to RE development (i.e., a relatively high interest rate that does not overly advantage RE as compared to diesel or other conventional generation assets).

\subsubsection{Fuel Cost}

The cost for diesel fuel used to operate the generators is approximately $\$ 1.00 /$ liter. Diesel fuel price for industry is adjusted to world oil price. A recently published price by Pertamina (Oct 31, 2014) was $\$ 0.886 /$ liter; prices just a few months earlier were $\$ 0.927 /$ liter. Considering the fluctuation in oil price and exchange rate, even with short term price declines, $\$ 1.00 /$ liter is representative over the long term and the life of these proposed projects. The study assumed that PLN purchases its fuel at a wholesale cost. A sensitivity analysis was performed on the fuel cost to determine the impacts on financial performance if the cost of diesel varies from $\$ 0.9 /$ liter to $\$ 1.20 /$ liter. 


\section{Lamandau District}

Previous RE optimization analysis for Lamandau District was conducted for the study Sustainable Energy in Remote Indonesian Grids: Feasibility Study for Integrating Renewable Energy

Technologies. The analysis found that PV and biogas from POME are both economically promising technologies in Lamandau district with POME having the greatest economic and technical potential to reduce the diesel fuel use with a renewable resource. Lamandau has experienced considerable growth in the past year, with an annual load growth of $20 \%$. With this large increase in demand and need for stability in power generation in Lamandau, the SERIG team decided to focus only on dispatchable RE from POME for updating the production cost model.

\subsection{Existing Diesel Gensets}

The area around Nanga Bulik, including all government offices, is connected to the main PLN grid (known as PLTD AMP) and is provided with electricity at all times. All generators are leased at the PLTD AMP facility and during the SERIG team's visit in February 2014, these generators were providing the majority of the load with only occasional backup support during peak hours from the nearby PLN owned and operated plant called PLTD Nanga Bulik. Diesel generator power plants and capacities are presented in Table 1.

Table 1. Diesel Power Plant and Capacities in Lamandau District (Feb. 2014)

\begin{tabular}{|l|l|l|l|}
\hline Diesel Power Plant & Status & $\begin{array}{l}\text { Installed } \\
\text { Capacity }\end{array}$ & $\begin{array}{l}\text { Operation } \\
\text { Hours (daily) }\end{array}$ \\
\hline PLTD AMP & Rented & $4 \times 800 \mathrm{~kW}$ & 24 \\
\hline PLTD Nanga Bulik & District Owned & $2 \times 500 \mathrm{~kW}$ & $4-5$ \\
\hline
\end{tabular}

The peak demand in February 2014 was approximately 2.4 MW and occurred in the evenings from 6 p.m. to 9 p.m. The base loads during the day were 1.7 MW. The PLTD Nanga Bulik generators only ran four to five hours per day. The generators at Nanga Bulik district owned facility were in fair condition and PLN was planning to retire them.

By the time the SERIG team visited in October 2014, the load had increased to an average of 2.4 MW during the day with the peak $3.4 \mathrm{MW}$ in the evenings. This increase in demand reflects an annual load growth of $20 \%$ and caused severe overheating in the main PLTD AMP plant. The PLTD Nanga Bulik power facility, that only ran four hours per day eight months earlier, was now running all the time to support the PLTD AMP plant and meet the increased demand.

The HOMER software uses an optimal dispatch strategy to minimize fuel consumption in the simulation of the power system. It selects the combination of generators that yields the lowest cost while meeting all load requirements. The baseline model was calibrated to match the annual fuel consumption.

The annual energy production and fuel usage of the HOMER model base case for 2013 is calculated at 4,860,000 liters (compared to 4,800,000 liters/year reported by PLN). The number of hours the modeled generators at PLTD Nanga Bulik plant ran is 1,449 hours/year (an average of 4.0 hours/day). The projected $\sim 20 \%$ load increase per year for three years is modeled with the summary of load data and fuel use presented in Table 2. 
Table 2. Summary of Load Data from Model

\begin{tabular}{|l|l|l|l|}
\hline Data & 2013 & 2014 & 2015 \\
\hline Average power (kW) & 1,851 & 2,221 & 2,665 \\
\hline Average (kWh/d) & 44,422 & 53,306 & 63,967 \\
\hline Peak Power (kW) & 2,558 & 3,069 & 3,683 \\
\hline Fuel consumption (Liters) & $4,860,000$ & $5,685,364$ & 6987,200 \\
\hline Annual production (KWh/year) & $16,214,000$ & $19,456,678$ & $23,347,962$ \\
\hline
\end{tabular}

\subsection{Resource Assessment from Palm Oil Mills}

Palm oil is a significant economic driver in Indonesia by providing income opportunities in rural areas. It is the world's leading vegetable oil produced and traded, and Indonesia is the largest producer. Growing worldwide demand for vegetable oils has led to a continual increase in oil palm plantation land area and palm oil production in Indonesia. The feedstock comes from large private plantations, smallholders, and state-owned plantations. Palm oil mills typically operate 24 hours per day, seven days per week, year-round. Palm oil mill effluent is currently processed through a series of ponds to reduce environmental toxins and stabilize it prior to final release to land or water; the final byproduct is methane rich to varying degrees depending on how efficient the particular mill is in converting feedstock to palm oil.

Most existing palm oil mills that capture the methane from POME generally use a flexible membrane to cover an existing anaerobic pond to collect the biogas-a combination of methane and carbon dioxide $\left(\mathrm{CO}_{2}\right)$ and traces of other gasses. The biogas is cleaned to remove impurities for use in a reciprocating gas engine to produce electricity and deliver to the grid.

Palm oil byproducts that have power generation potential include biogas from POME and solid biomass waste. The two palm oil mills closest to the PLN's distribution feeders are PT Gemareksa Mekarsari and PT Nirmala Agro Lestari (NAL) and energy production potential from these is quantified as:

- Palm oil mill effluent. From two palm oil mills in Lamandau, POME potentially could generate about 3.5 MWe (Table 3). Electricity generation equipment would be sized based on POME sampling at each candidate mill. In this project, electricity generation from a 45 -ton/hour facility is estimated at $1.52 \mathrm{MW}$; however, potential at any given mill may be higher or lower depending on the chemical oxygen demand (COD), effluent rate, extraction efficiency of palm oil, and general mill operations. Poorly run mills inefficient at extracting the maximum amount of palm oil may have POME rich in organic wastes capable of producing more than the $1.52 \mathrm{MW}$ used in the assumption. If a mill is highly efficient, it may produce less than $1.52 \mathrm{MW}$, making the POME less valuable for methane production.

- Solid biomass waste. The energy potential for electricity generation from solid biomass waste such as empty fruit bunch (EFB), shell and fiber of palm oil mills in Lamandau District is presented in Table 3 for two palm oil mills located close to PLTDs in Nanga Bulik. Most of the solid biomass is used for fuel in boilers for crude palm oil (CPO) production process. Further 
studies are needed to determine how much resource is left for potential biomass power plant. We estimate that $5 \mathrm{MW}$ of annual average power production could be produced from solid waste.

The calculations assume that one ton of CPO is generated from five tons of fresh fruit bunch (FFB), and one ton of FFB generates residues of 0.2 tons EFB, 0.22 tons of fiber, and 0.075 tons of palm shell. The effluent rate is generally $50 \%$ to $70 \%$ per ton FFB processed. If the primary energy-toelectricity conversion rate is $35 \%$, then the estimated total electricity generation capacity from biomass waste of two mills is about $5 \mathrm{MWe}$ average annual power output. The estimated generation of $5 \mathrm{MW}$ is based on the assumption that all solid biomass is utilized. This leads to total energy potential from POME (3.55 MW) and solid biomass waste (5 MW) to be about 8.55 MWe.

Table 3. Palm Oil Companies and Total Energy Potential from POME and Biomass Waste

\begin{tabular}{|l|l|l|l|c|}
\hline No & Company & $\begin{array}{l}\text { Production Capacity } \\
\text { (ton/hour CPO) }\end{array}$ & $\begin{array}{l}\text { Total Energy } \\
\text { Potential from } \\
\text { POME(a) (MWe) }\end{array}$ & $\begin{array}{l}\text { Estimated Generation } \\
\text { Capacity from EFB, } \\
\text { Shell \& Fiber (b) (MWe) }\end{array}$ \\
\hline $\mathbf{1}$ & PT Gemareksa Mekarsari & 60 & 2.03 & \multirow{2}{*}{5} \\
\hline $\mathbf{2}$ & PT Nirmala Agro Lestari (NAL) & 45 & 1.52 & $\mathbf{5}$ \\
\hline & SUBTOTAL & $\mathbf{1 0 5}$ & $\mathbf{3 . 5 5}$ & \\
\hline
\end{tabular}

(a) Assumption: FFB to POME ratio: 70\%, COD level: 55,000 ppm, operating hours: 6,000 h/year, and COD removal of 80\%. Source: Estimated from data in CIRCLE Project, Provinsi KalimantanTengah (2011).

(b) Estimated based on the assumption that the electricity generated has a capacity factor of $80 \%$ and that operating hours of the mills are 8,760 hours/year.

Source: Dinas Kehutanan dan Perkebunan, Lamandau, 2013.

Analysis by Winrock and NREL from the site visit to the two palm oil mills close to PLTDs (i.e., PT Gemareksa Mekarsari and PT NAL indicate that the potential from POME biogas to generate electricity presents the best opportunity for diesel displacement or supplementing existing power in PLN's nearby grid. Palm solid waste materials already are being utilized as fuel in boilers for the palm oil mill operation as well as for mulching or making fertilizer and it is assumed they are not available for power generation.

\subsection{Project Construction and Cost}

As described in the previous section, the potential power generation for PT Gemareksa Mekarsari is approximately $2 \mathrm{MW}$ and NAL is approximately $1.5 \mathrm{MW}$ and these could be interconnected at PLTD AMP.

The PLN standard cost of transmission lines for central Kalimantan is about IDR 400 million per km or $\$ 36,365 / \mathrm{km}$. These costs are assumed in this analysis for the cost to potentially interconnect POME biogas power plants. The distance is about $12 \mathrm{~km}$ from PT Gemareksa Mekarsari's potential biogas power plant to the "interconnection point" at PLTD AMP, whereas PT NAL is located about $14 \mathrm{~km}$ to PLTD Nanga Bulik (which is an incremental distance from PT Gemareksa Mekarsari). Table 4 summarizes the plant size, distance to interconnect to the electrical system at PLTD AMP and total cost to interconnect based on the assumed $\$ 36,365 / \mathrm{km}$ cost. 
Table 4. Distance and Cost to Interconnect with Palm Oil Mills

\begin{tabular}{|l|l|c|c|r|}
\hline No & Company & $\begin{array}{c}\text { Total Energy } \\
\text { Potential from } \\
\text { POME(a) (MWe) }\end{array}$ & $\begin{array}{c}\text { Distance to } \\
\text { interconnect } \\
\text { PLTD AMP }\end{array}$ & $\begin{array}{c}\text { Cost to } \\
\text { interconnect }\end{array}$ \\
\hline $\mathbf{1}$ & PT Gemareksa Mekarsari & 2.03 & $12 \mathrm{~km}$ & $\$ 436,380$ \\
\hline $\mathbf{2}$ & $\begin{array}{l}\text { PT Gemareksa Mekarsari and } \\
\text { PT Nirmala Agro Lestari }\end{array}$ & 3.55 & $14 \mathrm{~km}$ & $\$ 509,110$ \\
\hline
\end{tabular}

It appears that, with two biogas power plants, the sustainability of POME-based electricity supply in Lamandau could be achieved such that some of the diesel engines could be relocated to other unelectrified areas to improve electrification ratio of the sub-districts.

\subsection{Permits}

Permits needed to install electricity generation equipment at an existing palm oil mill are expected to be less of a barrier than stand-alone RE generation plants because the palm oil mill should already hold an existing license from the Indonesia Ministry of Agriculture. The water needed for the electricity generation process is minimal, and the mill or IPP should determine whether there are any issues with water permits. No additional land would be needed for this project because it would involve using existing area and installing equipment in the mill's engine room. However, for the mills considered in this study, additional land may be needed temporarily to divert the existing ponds while the membrane and earthworks are being installed.

\subsection{Project Model}

A cost analysis was done from the perspective of the utility, PLN, on extending a transmission line to one or both of the palm oil plants and purchase $2 \mathrm{MW}$ or $3.5 \mathrm{MW}$ at the current FiT of $\$ 0.1138 / \mathrm{kWh}$. A HOMER model was used to determine the most cost effective solution with lowest LCOE.

The biogas generators were assumed to be built and operated by the palm oil mill as an IPP. The biogas generators were sized to represent potential production from PT Gemareksa Mekarsari and PT Nirmala Agro Lestari. The model assumed that PLN would purchase the electricity at a $\$ 0.1138$ $/ \mathrm{kWh}$ (feed-in-tariff for Kalimantan). ${ }^{8}$ In this scenario NREL assessed if it was worthwhile for PLN to purchase biogas at the current FiT rate and also to pay for the line extension to one or both plants to access this low cost electricity.

The analysis assumed diesel fuel costs $\$ 0.90 /$ liter.

\subsection{Production Cost Modeling Results for Lamandau}

Results of the analysis show that it would be cost-effective to build $14 \mathrm{~km}$ of transmission to purchase power from both POME biogas power plants $(3.5 \mathrm{MW})$ at the current FiT rate. At the assumed line extension costs, PLN would save approximately $\$ 2.9$ million/year in diesel fuel costs and realize a net present value (NPV) of \$31 million in total life-cycle savings over a 25 year power purchase agreement (PPA) term. The total levelized cost for electricity for PLN from the POME

\footnotetext{
${ }^{8}$ Regulation of MEMR Minister No. 27/2014.
} 
biogas plants would be approximately $\$ 0.14 / \mathrm{kWh}$ inclusive of the $\$ 0.1138 / \mathrm{kWh}$ FiT and line extension.

A sensitivity was done on increased FiT, or PPA price, to determine at what price limit it would be cost effective to extend the transmission line and purchase electricity from both mills $(3.5 \mathrm{MWe})$ and/or just one palm oil mill (2 MWe). Table 5 shows the results using 2015 load profile (3,683 $\mathrm{kW}$ peak) and present diesel price of \$0.9/liter. The LCOE column shows the blended LCOE for PLN's self-generated diesel plant and power purchased from a potential IPP under the different FiT scenarios.

Table 5. Optimum Results with Increased FiT for POME

\begin{tabular}{|c|c|c|c|}
\hline $\begin{array}{c}\text { Power from 1 or } \mathbf{2} \\
\text { Mills (MWe) }\end{array}$ & $\begin{array}{c}\text { Capital } \\
\text { Cost }\end{array}$ & $\begin{array}{c}\text { FiT } \\
(\mathbf{\$} / \mathbf{k W h})\end{array}$ & $\begin{array}{c}\text { LCOE } \\
(\mathbf{\$} / \mathbf{k W h})\end{array}$ \\
\hline 3.5 MWe & 509,110 & $\mathbf{0 . 1 1}$ & 0.140 \\
\hline 3.5 MWe & 509,110 & $\mathbf{0 . 1 8}$ & 0.247 \\
\hline $\mathbf{2 . 0}$ MWe & 436,380 & $\mathbf{0 . 2 0}$ & 0.273 \\
\hline $\mathbf{2 . 0} \mathbf{M W e}$ & 436,380 & $\mathbf{0 . 2 4}$ & 0.302 \\
\hline 0 MW & 0 & $\mathbf{0 . 2 8}$ & 0.306 \\
\hline
\end{tabular}

The results indicate that it is cost effective to purchase power from both palm oil mills at the current FiT and up to $\$ 0.18 / \mathrm{kWh}$. The sensitivity analysis shows that if the FiT increased to $\$ 0.20 / \mathrm{kWh}$ then it would be cost effective to only extend the transmission line to the closer palm oil plant (2MW). At a FiT of $\$ 0.28 / \mathrm{kWh}$, the results indicate that it would not be cost effective for PLN to purchase power from either palm oil plants at the assumed line extension costs. Lower costs for line extension or higher diesel fuel costs would change the break-even point for purchased power.

A POME project would perform very well economically primarily because of PLN's avoided cost of diesel generation, which is roughly three times what it would pay for electricity generated by the project. This means that the majority of the benefit is captured by PLN.

The analysis indicates that extending the transmission line and purchasing electricity from both palm oil mills is likely economical at current FiT of $\$ 0.1138 / \mathrm{kWh}$. With the significant load growth of $20 \%$ annually, PLN might want to consider investing in transmission lines that extend to the palm oil mills to increase their generation and help meet their growing demand for electricity. This analysis indicates that POME biogas generation and line extension is less costly than expanding a fleet of diesel generators and/or purchasing diesel generated power at PLTD AMP or PLTD Nanga Bulik.

Currently, Winrock is in contact with the palm oil mill owners at their main offices in Jakarta to discuss generating electricity from their POME with pre-feasibility study assistance. According to PLN's Lamandau sub-branch manager, PLN would construct the required transmission line from the two mills to PLN's existing $20 \mathrm{kV}$ lines as long as it is stated in the PPA that new customers in the area would be provided with power. Again, in this case the local government and PLN will need to play an important role in developing POME biogas as an electricity opportunity with the mill owners. This is a crucial issue for ultimate project success. 


\section{Sabu Island}

A previous RE optimization analysis was presented in the document "SERIG: Feasibility Study for Integrating Renewable Energy Technologies." The analysis found that wind and PV are both economically promising technologies on Sabu Island relative to diesel generation. However, wind technology requires additional resource assessments and permitting for near term project deployment. For this reason the SERIG team focused on updating the production cost model for deploying PV with battery storage.

\subsection{Existing Diesel Gensets}

There are eight diesel generators at the Seba power plant with only six of them operating when NREL visited in October 2014. The total installed capacity is $2 \mathrm{MW}$ with actual capacity of 1,700 $\mathrm{kW}$. The night/peak load is $1 \mathrm{MW}$ at about 8:00 p.m. while the day/base load is between 500-600 $\mathrm{kW}$. The average diesel fuel consumption is between four and five tons per day or 4,516 and 5,645 liters per day. The average energy production is $13,744 \mathrm{kWh} / \mathrm{d}$. The production has increased $\sim 10 \%$ annually since 2012 when reported production was $12,498 \mathrm{kWh}$ /day and the average diesel fuel consumption was about 3,605 liter/day (the specific fuel consumption (SFC) is 0.288). ${ }^{9}$ Since the annual production and load growth is estimated at $10 \%$, a sensitivity analysis was performed around load growth in the production cost modeling.

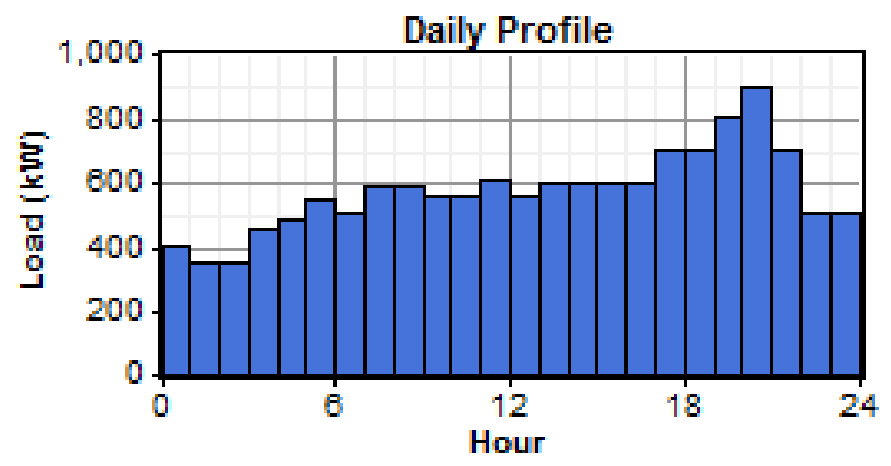

Figure 3. Daily load profile for Seba power plant.

The base load data is summarized in Table 6.

Table 6. Summary of Load Data from Production Cost Model

\begin{tabular}{|l|l|}
\hline Data & Total \\
\hline Average power (kW) & 573 \\
\hline Average (kWh/d) & 13,744 \\
\hline Peak Power (kW) & 980 \\
\hline Load factor & 0.58 \\
\hline Annual fuel consumption (Liters) & $1,756,300$ \\
\hline Average Annual production & $5,016,561 \mathrm{kWh} /$ year \\
\hline
\end{tabular}

${ }^{9}$ Data from: Sabu Raijua dalam angka 2012. 
Each of the gensets is assumed to have a lifetime of 45,000 operating hours, before a $\$ 1,000 / \mathrm{kW}$ replacement/overhaul cost is incurred. In addition, each genset incurs an operation and maintenance cost equal to $\$ 0.010$ times its continuous output capability for every hour of operation. The fuel costs make up the remaining cost of operating the gensets, accounting for $\sim 70 \%$ to $80 \%$ of the total cost. Since the fuel costs provide the largest proportion of generation costs, strategies to reduce fuel usage provide the greatest opportunity for cost savings.

\subsection{Solar Resource}

The solar resource data for this analysis is from NASA's surface solar energy (SSE) data set, which provides monthly average solar radiation data for anywhere on earth. The resolution is a $40 \mathrm{~km}$ grid. ${ }^{10}$ The solar resource used for Sabu Island is centered at about $10^{\circ} 30^{\prime} \mathrm{S}$ latitude and $121^{\circ} 53^{\prime} \mathrm{E}$ longitude. More information about SSE can be found at http://eosweb.larc.nasa.gov/sse/.

Sabu Island has an excellent solar resource. According to data from NASA's SSE database, the average annual solar resource is $\sim 6.5 \mathrm{kWh} / \mathrm{m}^{2}$ per day. This is also called full sun hours or peak sun hours because $1 \mathrm{~kW}$ per square meter is the approximate solar radiation at noon on a clear day. Figure 4 shows the solar resource, locations of various PV projects, and the diesel powerhouse on Sabu Island.

${ }^{10}$ NASA Atmospheric Science Data Center. (2011). Surface Meteorology and Solar Energy.

A Renewable Energy Resource Web Site (release 6.0). http://eosweb.larc.nasa.gov/sse/. Accessed July 2014. 


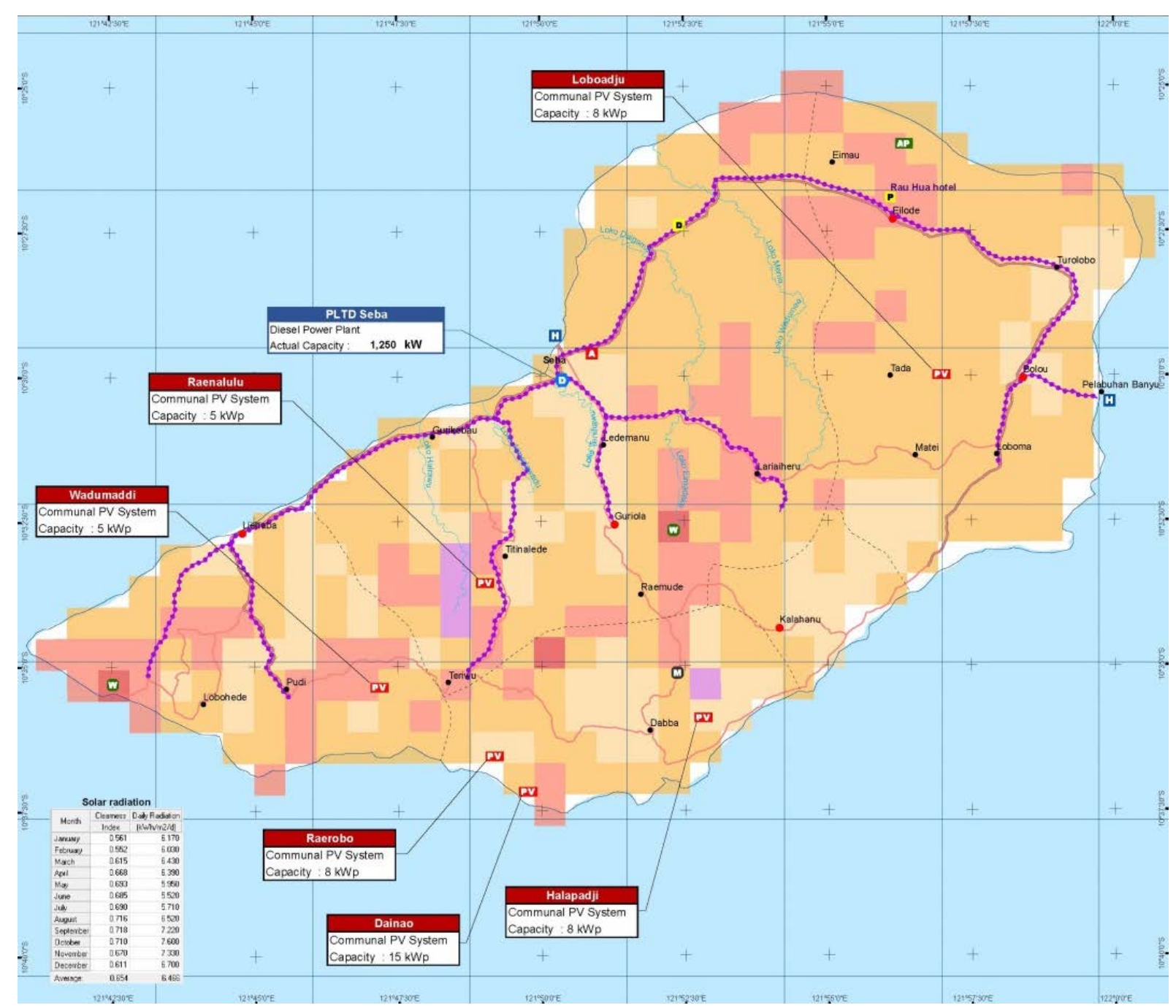

Figure 4. Map of Sabu Island with solar - resources.

Source: NREL and Winrock International

\subsection{Solar Project Opportunities}

The solar potential is excellent and is consistent with the government's planning to continue to support PV development. The local government of Sabu confirmed that land could be made available for utility-scale PV development that is near the hospital, government buildings and Seba power plant. This is likely the preferred location because much of the load and growth is happening in this area; it will be the least cost location to facilitate grid integration of large amounts of PV.

\subsection{Cost of Photovoltaics}

The cost of PV is coming down worldwide, as is documented in IEA PVPS January $2014 .{ }^{11}$ The average European cost for commercial PV systems is less than $\$ 4.00 / \mathrm{W}$ and utility scale ( $>5 \mathrm{MW}$ ) is even less at an average of $\$ 2.00 / \mathrm{W}$.

\footnotetext{
${ }^{11}$ International Energy Agency Photovoltaic Power Systems Program, January 2014.
} 
The cost of $\mathrm{PV}$ on islands and remote systems typically is $\$ 1.00 / \mathrm{W}$ to $\$ 2.00 / \mathrm{W}$ higher. The cost depends largely on the accessibility of the site and the environmental conditions of the area.

The primary consideration for investing in PV is the ability to source and install low cost PV equipment and cost effectively displace diesel fuel.

Because there is uncertainty about the actual cost of a PV system and the cost of diesel fuel for Sabu, NREL ran a sensitivity analysis for the capital costs of PV as compared to the varying price of diesel to determine the cost at which a PV system becomes economical. The analysis examined PV system costs from $\$ 2.50 / \mathrm{W}$ to $\$ 6.00 / \mathrm{W}$. Figure 5 indicates that for diesel prices between $\$ 0.90 /$ liter up to $\$ 1.20 /$ liter PV is recommended at costs under $\$ 5.00 / \mathrm{W}$ and as diesel prices rise above $\$ 1.05 /$ liter $\mathrm{PV}$ is recommended even at $\$ 6.00 / \mathrm{W}$ installed.

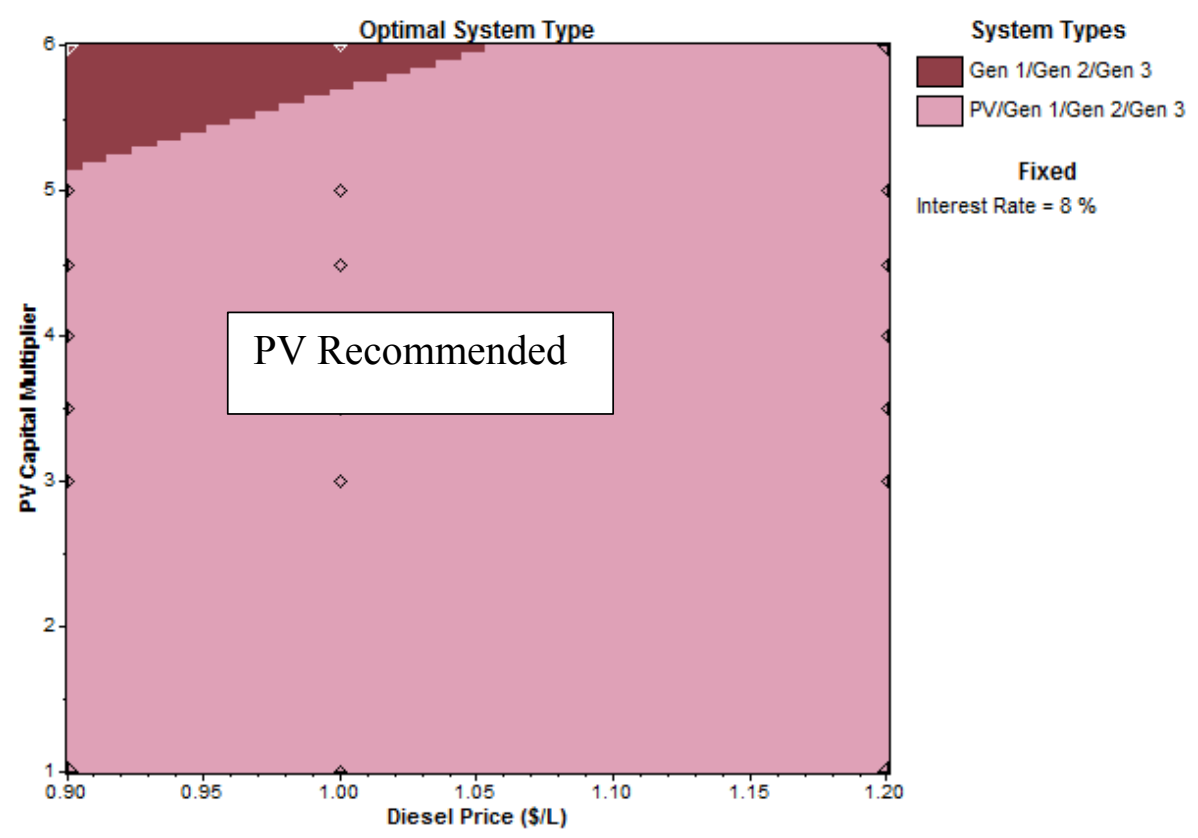

Figure 5. Sensitivity analysis on PV installed cost $(\$ / W)$ and diesel escalation price.

\subsection{Production Cost Modeling Results for Sabu Island}

The production cost modeling results presented are the costs of generating electricity to meet the projected load demands and operating reserve requirements of the island. The costs do not include the additional cost of distributing electricity (including transmission and distribution upgrades and maintenance). The results are based on a techno-economic feasibility analysis that includes an annual hourly chronological dispatch to ensure that supply meets demand within each hour. The simulated results are used to determine the expected costs of operating the described system for 25 years.

\subsection{Operating Reserve}

HOMER enforces an operating reserve (spinning reserve) constraint that requires the system to have sufficient capacity online to cover sudden drops in output from the wind or PV systems. This reflects how conservative the utility will be with regard to the variability of the renewable resources. A $100 \%$ operating reserve constraint requires the system to have sufficient spinning reserve to cover the complete loss of solar output within each of HOMER's one-hour simulation time steps. A less 
conservative assumption is that the system only needs spinning reserve sufficient to cover $25 \%$ of the solar output in any hour.

More detailed analyses considering short-term fluctuations in the resources, the "stiffness" of the rural grids, and other technical factors are required before recommendations regarding the appropriate level of operating reserve can be made. For example, 100\% operating reserve could be most appropriate if all of the PV is packed into a single array. If multiple smaller arrays are sufficiently separated geographically, then individual clouds will not have the same nearsimultaneous impact on the system output, and a lower level of operating reserve could be possible. Amounts and types of energy storage would also factor into the recommendation on percent of operating reserves. A $100 \%$ operating reserve requirement reduces the cost-effectiveness of PV significantly. For this analysis, NREL assumed the HOMER default values for operating reserve of $25 \%$ for PV.

The modeling results presented here do not consider individual feeder limitations and constraints, which will need to be explored in subsequent interconnection modeling. It does, however, include the need to switch on generators to meet load and reserve requirements, as well as assuming that solar generation only contributes $75 \%$ "reliable" electricity, that is, un-curtailed solar generation must be backed up with spinning reserves equal to $25 \%$ of solar power output.

\subsection{PV System Without Batteries}

Adding a high penetration of variable and non-dispatchable PV generation (i.e., no battery storage) will increase the need for controls to avoid excessive ramp rates on the generation, or overvoltage issues on the distribution lines. HOMER identifies potential impacts of variable generation on the electric power system as it relates to the instantaneous maximum RE penetration level. IEEE Std 1547.2 Application Guide for IEEE 1547 Standard for Interconnecting Distributed Resources with Electric Power Systems specifies a 10-15\% penetration limit to peak loads and was used to determine aggregate PV system size that wouldn't negatively affect the dispatching of the generators. For Sabu Island, at the present load, the amount of PV that can be added to the base case diesel generators without storage or complex controls is $\sim 350 \mathrm{~kW}$. The $350 \mathrm{~kW}$ of PV would provide $\sim 13 \%$ electrical production to the total load. The project would realize a NPV savings of $\$ 628,000$ and a simple payback of eight years.

\subsection{Storage}

From a broad grid perspective, the key attributes of importance for Sabu Island in the near term is reserve support to improve the dispatch of the generators and reduce the diesel fuel use. We focus on reserve support because this will become more important as the amount of variable renewables on the system increases. In this study, NREL and Winrock analyze the system with lead-acid battery technology since these batteries are already deployed on the island and the technology is familiar to local residents, available, and considered mature.

System designs that include greater relative capacities of variable RE benefit from energy storage to help increase the value of the RE in the design and to help regulate the grid and keep it stable. The modeling analyzes the economics of adding storage (batteries) to a PV/generator hybrid system on Sabu Island. A typical diesel-based island electricity system with storage can be cost-effective even in the absence of RE through the ability to maximize diesel generator efficiency and thereby reduce 
diesel consumption. Conversely, without energy storage, the size and operation of the recommended PV system would be more limited because of the variable, intermittent nature of solar energy and the impact the fluctuating PV would sometimes have on the diesel grid.

The mature technology of lead-acid batteries is modeled because it has moderate costs and high reliability. A combination of renewables, storage, and diesel generators - all carefully sized and integrated - can yield the lowest-cost solution (based on the levelized cost of electricity). For small scale (up to $10 \mathrm{MW}$ ) installations, lead-acid batteries are the most common storage technology system. ${ }^{12}$

In HOMER, the energy storage system is modeled as two distinct components: battery and inverter/charger. Technical information regarding the cycle life and capacity curves for battery technology along with cost information is entered as HOMER inputs. HOMER simulations take into account the duty cycle on the battery along with replacement and O\&M cost to derive a project period life-cycle cost. The inverter/charger is modeled separately as the component that is the link between the AC and DC busses.

The advanced lead acid battery Absolyte GP 100G99 was modeled; it is a deep-cycle battery with an initial cost of $\$ 5,625$ per $9.6 \mathrm{kWh}, 4,800$ Ah battery system. The converter was modeled with a capital cost of $\$ 107,733$ for $100 \mathrm{~kW}$ and a replacement cost of $\$ 95,000$. Various sizes of PV were modeled (from $300 \mathrm{~kW}$ to $1 \mathrm{MW}$ ) with various numbers of battery strings ( 24 cells/string) and projected load increase over a three-year period. The results (Figure 6) are modeled with a PV cost of $\$ 4.50 / \mathrm{W}$ and $8 \%$ interest rate. The $1,000 \mathrm{~kW}$ of $\mathrm{PV}$ can provide $2,043,045 \mathrm{kWh} /$ year or $35 \%$ of the overall electrical production to meet the load. The annual battery throughput is $\sim 36,500 \mathrm{kWh} / \mathrm{yr}$ with an expected life of 16 years. It should be noted that given the size of the current load on Sabu, $1000 \mathrm{~kW}$ of PV would not be feasible without energy storage because the PV variability would be too extreme for the diesel gensets.

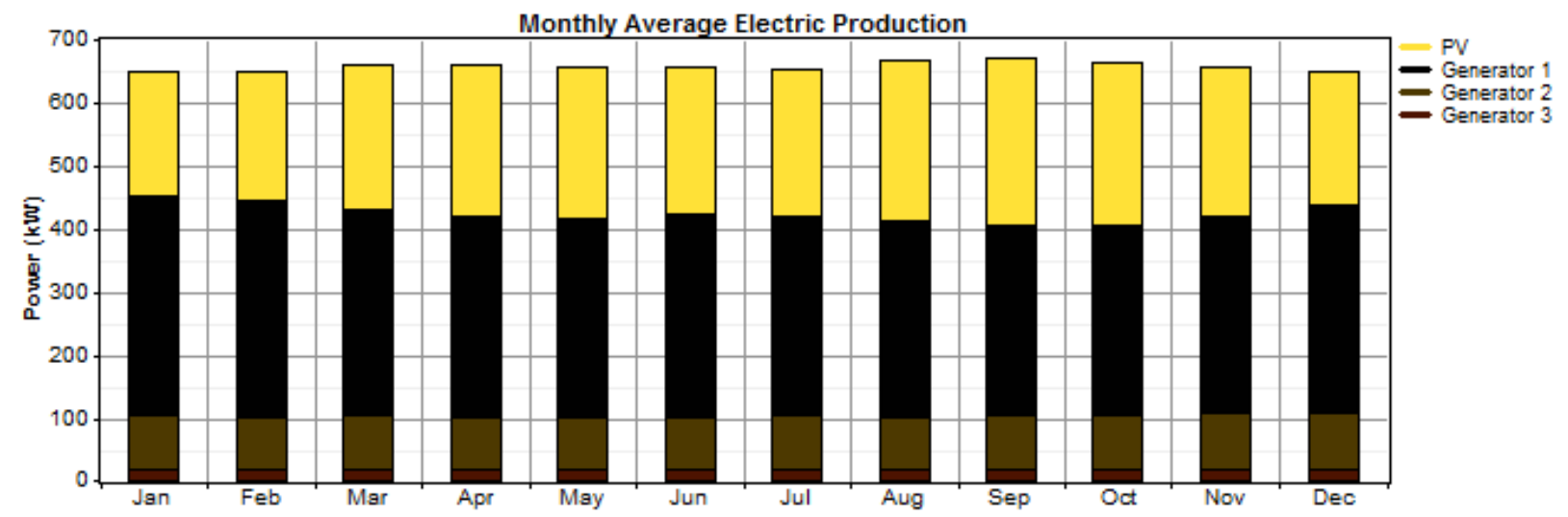

Figure 6. Monthly average electric production.

${ }^{12}$ IRENA, Electricity Storage and Renewables for Island Power, May 2012. 


\subsection{Summary of Investments in Solar PV}

The opportunities for integrating PV and batteries on the island of Sabu are economically promising for PLN and have the potential to reduce the demand on fossil fuels. The production cost modeling indicates that a PV/battery system is competitive with diesel generation over a large range of diesel fuel prices (Figure 7). Adding $1 \mathrm{MW}$ of PV and 48 Absolyte GP 100G99 batteries (36.5 $\mathrm{MWh} /$ year) would realize a NPV savings of $\sim \$ 2$ million over a 20-year period compared to the present base case with only diesel generation.

Adding batteries is also cost effective for a PV hybrid system (PV prices at about $\$ 4.50 / \mathrm{W}$ and $8 \%$ interest rate) and can reduce the impact of variable generation on the electrical system. The HOMER analysis indicated that adding batteries can reduce the use of diesel fuel-and thus the LCOE of the electrical system. The model indicated that the most cost-effective method is to add a large amount of PV (900-1,000 kW) and a moderate amount of storage (48 battery cells or $461 \mathrm{kWh}$ ) to the present 2014 load and phase in additional PV with storage as the loads increase over the next few years.

The surface plot (Figure 7) shows that the optimum hybrid system (PV-diesel-battery) recommends adding PV capacity from $800 \mathrm{~kW}$ to $1 \mathrm{MW}$ in stages as the load demand increases over three years (x-axis). Each different color represents the recommended size PV capacity array, with the color black being $800 \mathrm{~kW}$ (recommended for 2013 load) and red represents $1 \mathrm{MW}$ (recommended for loads 2014- 2015 and beyond).

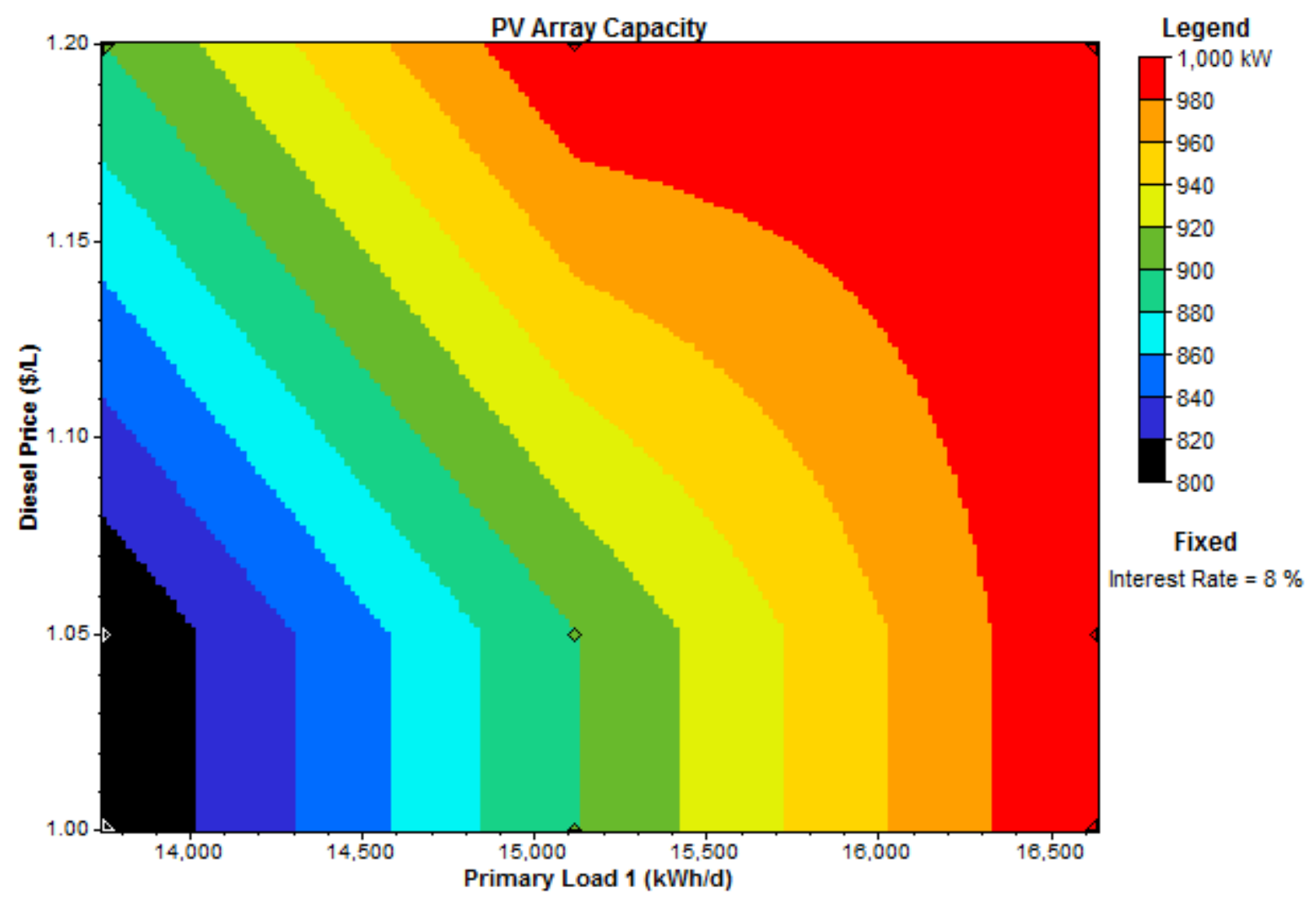

Figure 7. Recommended PV array capacity across the range of projected loads. 


\subsection{Integration Services: Storage and Balance of System Management}

In addition to understanding the financial impact of high contribution RE on islanded electrical systems, it is critical to also understand how these systems will impact existing generation and distribution infrastructure and system behavior. To accurately size and integrate variable renewables such as PV, additional power system models-specifically load-flow, stability, short-circuit, protection and coordination studies - must be done. Accurate model simulations are critical for planning overall grid quality and safety. Additional costs to address the system impacts may affect the economics of the project.

If a low penetration of RE is installed on Sabu Island, additional storage may not be necessary (300$400 \mathrm{~kW}$ ). If the level of variable renewable penetration is sufficiently high, however, then storage, demand management, and balance of system controls will be necessary to maintain system stability. The responsibility for these integration services will be determined by the contracts, but the technical issues will remain and should be addressed. Without sufficient integration services, the variable renewables will need to be curtailed occasionally to maintain system stability. Responsibility and payment for curtailment should be considered in any PPA.

If PLN is responsible for the costs of curtailment, i.e., they own the RE generation asset or have a "take or pay" clause in their PPA with an IPP, incentives would exist to install appropriate integration services to manage the integration of variable renewables. The provision of integration services is a future business opportunity, but is contingent on the installation of new variable renewable supply.

\subsection{Summary of Investments in Integration Services}

Integration services are only necessary once the PLN grid transitions from a grid with lowpenetrations of variable RE to medium- and high-penetrations of variable RE. The value will depend heavily on the structure of the PLN's grid and associated power demand. Integration services require substantial coordination between the renewable and conventional generating assets. Specifying this coordination through contractual arrangement may be possible, but would entail large transaction costs and complicated negotiations. This argues for an integrated ownership and management structure. Large mainland utility systems sometimes rely on markets for independent power producers to provide ancillary integration services, but a small island like Sabu does not have the economies of scale and scope to maintain that kind of market for ancillary services. 


\section{Sumba}

Sumba is an island located in NTT Province, with a population of approximately $675,000{ }^{13}$ people and an electrification ratio of about $25 \% .{ }^{14}$ Sumba was initially not selected as a potential pilot project site during the initial screening study performed under SERIG due to PLN's concerns of overlap with ongoing RE activities. More recently, it has been determined that these ongoing activities may offer synergies that could facilitate project development, such as financing partners, data sharing, and government support, and that the SERIG team can add unique value to the grid integration component that will be required with a high penetration RE-diesel hybrid system. This section of the report explores Sumba's characteristics and the key considerations for implementing a wind-based RE project there.

\subsection{Energy Resources and Demand Characteristics}

Sumba is endowed with extensive RE resources for potential wind, hydro, solar, and biomass projects. It has low economic development, but reasonably extensive infrastructure for transportation and electricity distribution. Sumba can also be reached relatively quickly from Jakarta and Kupang. As a result, Sumba was selected by the Dutch NGO, Hivos, as a showcase for RE in remote locations.

In 2009, Hivos took the initial steps to start what is now the Sumba Iconic Island (SII) initiative. Through it, Hivos is working with a range of local and national-level Indonesian government organizations, multinational donors, NGOs, and technical experts with a goal to increase the electrification ratio of Sumba to $95 \%$ with $100 \%$ of the electricity supply coming from RE sources by 2025 . The intent is to use the SII initiative as a model for such projects throughout Indonesia and around the world. This is a distinctive opportunity for SERIG to participate and contribute to an important local effort that could provide lessons learned and application for many locations.

Based on Winrock's direct knowledge and involvement with SII activities, the SERIG team has identified an ongoing wind power development project (detailed below) with characteristics that align with SERIG's goals and approach.

\subsection{Electricity Supply}

Sumba's electricity distribution system is made up of two main grids, fed primarily by diesel generators, with an installed capacity of roughly $13 \mathrm{MW} .{ }^{15}$ The total nighttime peak load of the Waingapu and Waikabubak systems is about 9.3 MW while the daytime peak load is $5.9 \mathrm{MW}{ }^{16}$ Energy demand on this island is expected to increase in proportion to regional economic development and population growth, along with available energy. Figure 8 shows the existing PLN $20 \mathrm{kV}$ medium voltage Waingapu and Waikabubak grids. According to PLN's planning documents, the systems were scheduled to interconnect in 2014, but that time has passed and a new scheduled date has not yet been established. ${ }^{17}$

\footnotetext{
13 “Baseline Data of Sumba Island,” Winrock International, 2011.

14 “Scaling Up Renewable Energy Access in Eastern Indonesia, Inception Report,” ADB, November 18, 2013.

${ }^{15}$ PLN NTT.

${ }^{16}$ PLN NTT.

17 “Rencana Usaha Penyediaan Tenaga Listrik (Power Supply Business Plan), 2012-2021,” PLN.
} 


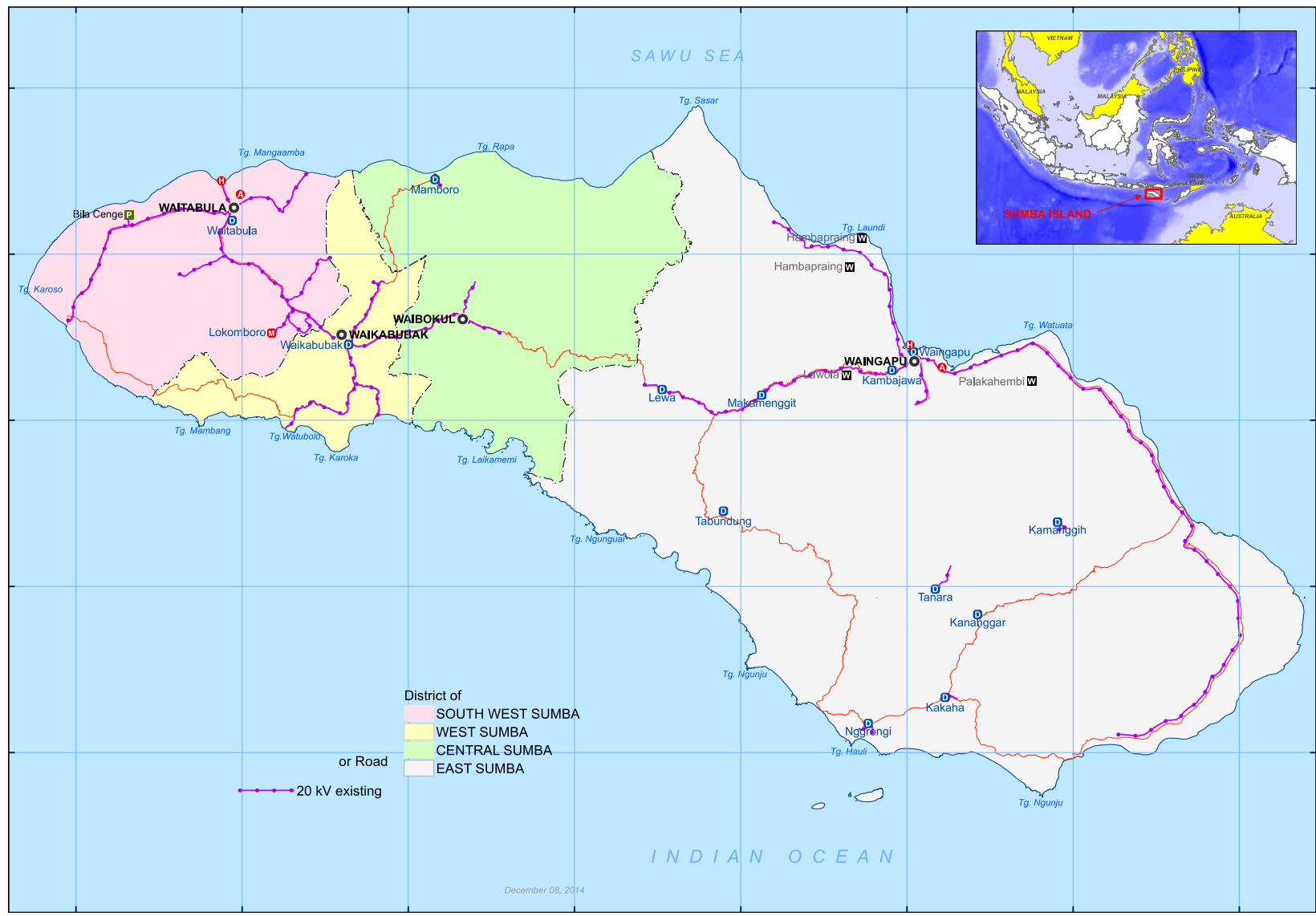

Figure 8. Sumba's electricity grid.

Source: PLN data compiled by Winrock International and "Fuel Independent Renewable Energy 'Iconic Island', Preliminary Resource Assessment of Sumba and Buru Islands - Indonesia, ” Winrock International, August 2010.

A Winrock analysis from 2009 data indicates that the generation cost of medium voltage power amounts to IDR 2,433 (\$0.21) per kWh, while low voltage production cost was IDR 3,072 per $\mathrm{kWh}$ $(\$ 0.26) .{ }^{18}$ The selling price of electricity was IDR $900(\$ 0.08)$ per $\mathrm{kWh} .{ }^{19}$ As a result the Government of Indonesia incurred a loss of roughly IDR 1,533 per kWh (\$0.13) sold on Sumba at that time (assuming medium voltage and IDR 12,000 to \$1.00). The high speed diesel fuel component contributed about $75 \%$ to the cost of power generation at medium voltage

\subsection{Ongoing Projects and Plans}

With the evolution of the SII initiative alongside other donor-led programs and PLN's own activities, a range of new projects and planning documents exist. Coordination and planning amongst these efforts have not always been well aligned, though efforts such as this report and related collaborations are intended to facilitate future coordination.

\footnotetext{
18 “Fuel Independent Renewable Energy 'Iconic Island', Preliminary Resource Assessment of Sumba and Buru Islands Indonesia," Winrock International, August 2010.

19 “Scaling Up Renewable Energy Access in Eastern Indonesia, Inception Report,” ADB, November $18,2013$.
} 
PLN's primary planning document, the Rencana Usaha Penyediaan Tenaga Listrik (RUPTL) or Power Supply Business Plan for 2012-2021, forecasts demand growth and provides long term plans for how PLN will meet it. In the plan, PLN anticipates a growth in peak demand from 4.6 MW in 2012 to $16.4 \mathrm{MW}$ in 2020 , and expects that roughly $41 \%$ of the 2020 peak demand will be met with diesel generation, and only $0.5 \mathrm{MW}$ will come from "hybrid power." Since the release of the RUPTL, however, demand has been stronger than planned and PLN has revised its planning to better align with SII objectives and ongoing activities.

In particular, PLN now plans to install approximately 1.8 MW of solar PV capacity for isolated community systems, which will likely be interconnected with the grid over time. ${ }^{20}$ In addition, PLN plans to add 6.5 MW of grid-connected solar power at sites in Bilacenge, Waingapu, and Laipori over the next two years, and bring the total hydro capacity in Sumba to $10.4 \mathrm{MW}$ by $2016 .{ }^{21}$

Specific ongoing or planned efforts included in these new PLN plans for Sumba include:

- Full integration of the existing $500 \mathrm{~kW}$ solar PV smart grid facility at Bilacenge

- $2 \times 400 \mathrm{~kW}$ expansion of the 2.4 MW Lokomboro hydro facility

- 1000 Island Project, through which the Government of Indonesia and the World Bank are implementing an integrated RE mapping and planning program in various locations in eastern Indonesia.

\subsection{Waikabubak Grid}

According to PLN records, the Waikabubak system had a nighttime peak load of $4.5 \mathrm{MW}$ and a daytime peak load of 3.2 MW in June of 2013 (Table 7). Data from 2011, as shown in Figure 9, shows a nighttime peak load of roughly $3.3 \mathrm{MW}$, indicating a $36 \%$ increase over two years. Assuming this growth rate remains constant, by 2020 , the peak load could be expected to be 14.6 MW with a base load of $8 \mathrm{MW}$. Currently, the load is served by a mix of PLN owned diesel generators, rented generators, and the hydro facility at Lokomboro. PLN is in the process of completing construction of $2 \times 400 \mathrm{~kW}$ of new capacity at the hydro facility. In addition, although not included in PLN's daytime load data shown in Table 7, the $500 \mathrm{~kW}$ solar facility at Bilacenge is operational; PLN is limiting the amount of electricity it supplies to the grid to avoid potential issues with fluctuations in supply.

\footnotetext{
20 “Scaling Up Renewable Energy Access in Eastern Indonesia, Inception Report,” ADB, November 18, 2013.

21 “Scaling Up Renewable Energy Access in Eastern Indonesia, Inception Report,” ADB, November 18, 2013.
} 
Table 7. Waikabubak System Supply (June 2013) Source: PLN NTT

\begin{tabular}{|c|c|c|c|c|}
\hline \multirow{2}{*}{ POWER PLANT } & \multirow{2}{*}{ TYPE } & \multirow{2}{*}{ POWER (kW) } & \multicolumn{2}{|c|}{ PEAK LOAD (kW) } \\
\hline & & & DAY & NIGHT \\
\hline \multirow{8}{*}{ WAIKABUBAK } & $6 \mathrm{ML}-\mathrm{HTS}$ & 180 & - & 146 \\
\hline & 6ML-HTS & 180 & - & 152 \\
\hline & BA 6 M $816 \mathrm{U}$ & 150 & - & - \\
\hline & DRO 216 & 210 & - & 210 \\
\hline & TBD 616 V12 & 250 & - & - \\
\hline & 12 V 2000 G 62 & 380 & 230 & 306 \\
\hline & D2842 LE 201 & 400 & 290 & 310 \\
\hline & 12 V 2000 G 62 & 350 & 230 & 275 \\
\hline RENTAL & & 600 & 574 & 620 \\
\hline \multirow{3}{*}{ WAITABULA } & TAD 1630GE & 150 & - & - \\
\hline & D 2866 LE 201 & 200 & - & 194 \\
\hline & D 2842 LE 201 & 400 & - & 373 \\
\hline \multirow{2}{*}{ RENTAL } & EGS 1200/800 & 650 & 602 & 648 \\
\hline & EGS $1200 / 800$ & 650 & 592 & 645 \\
\hline \multirow{5}{*}{$\begin{array}{l}\text { LOKOMBORO } \\
\text { (HYDRO) }\end{array}$} & SIMPLE HORIZ & 800 & - & - \\
\hline & Frances & 500 & - & - \\
\hline & Frances & 500 & 500 & 500 \\
\hline & kaplan & 250 & - & - \\
\hline & kaplan & 250 & 140 & 135 \\
\hline \multirow{5}{*}{$\begin{array}{l}\text { BILACENGE } \\
\text { (SOLAR) }\end{array}$} & & 96 & - & - \\
\hline & & 96 & - & - \\
\hline & & 96 & - & - \\
\hline & & 96 & - & - \\
\hline & & 96 & - & - \\
\hline & TOTAL & 7,530 & 3,158 & 4,514 \\
\hline
\end{tabular}

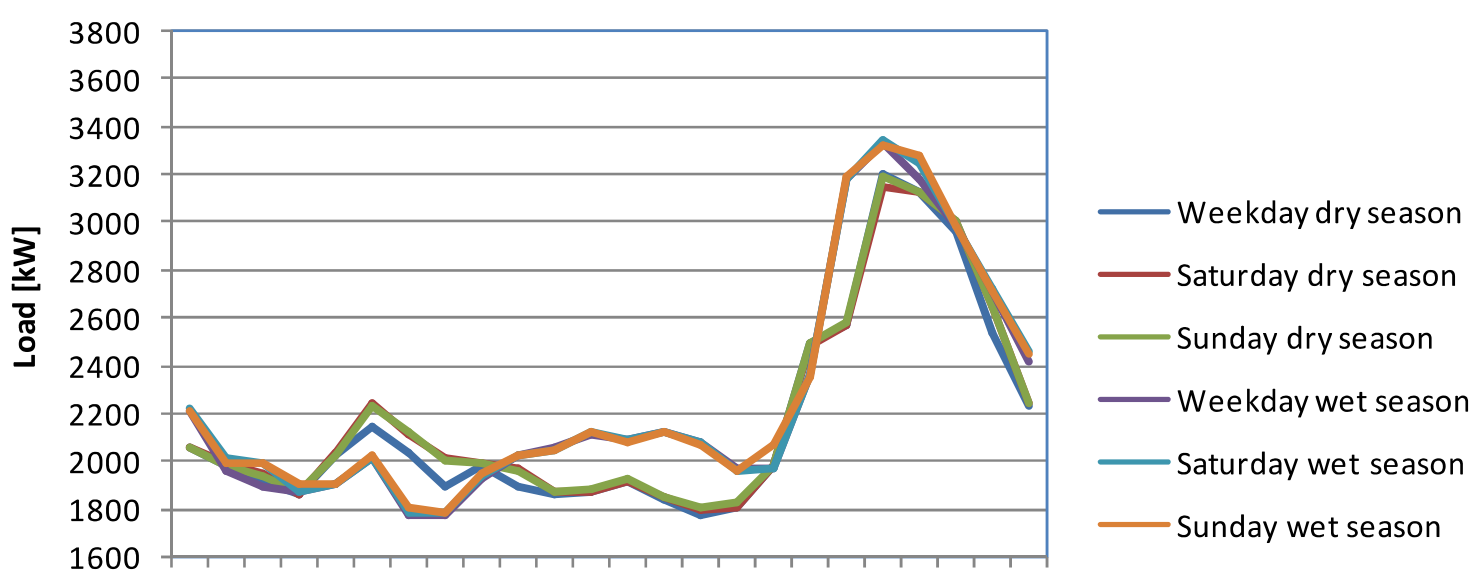

1223455667889101112131415161718192021222324

Hours of one day

Figure 9. Typical load pattern for Waikabubak grid.

Source: "Sumba Iconic Island Report - Grid Connected Electricity Generation," Hivos (KEMA), April 2011. 


\subsection{Waingapu Grid}

The Waingapu system had a nighttime peak load of $4.8 \mathrm{MW}$ and daytime peak load of $2.7 \mathrm{MW}$ in June of 2013 (Table 8). The data from 2011 in Figure 10 shows a nighttime peak load of approximately $3.65 \mathrm{MW}$, indicating a $32 \%$ increase over two years. Extrapolating this out to 2020, the base load then would be $6.8 \mathrm{MW}$ and the peak load would be $13.9 \mathrm{MW}$.

Table 8. Waingapu System Supply (June 2013)

Source: PLN NTT

\begin{tabular}{|c|c|c|c|c|}
\hline \multirow{2}{*}{ POWER PLANT } & \multirow{2}{*}{ TYPE } & \multirow{2}{*}{ POWER (kW) } & \multicolumn{2}{|c|}{ PEAK LOAD (kW) } \\
\hline & & & DAY & NIGHT \\
\hline \multirow{7}{*}{ WAINGAPU } & DRO 216 & 220 & - & - \\
\hline & 6ML-HTS & 220 & - & 195 \\
\hline & BA 6 M 816 U & 180 & - & 150 \\
\hline & BA 6 M 816 U & 180 & - & - \\
\hline & DRO 216 & 220 & - & 180 \\
\hline & DRO 216 & 220 & - & 180 \\
\hline & C32 & 550 & - & 530 \\
\hline \multirow{3}{*}{ KAMBAJAWA } & TAD $1630 \mathrm{GE}$ & 220 & - & 215 \\
\hline & 18V2000G62 & 650 & 515 & 630 \\
\hline & D2842LE201 & 430 & - & 430 \\
\hline \multirow{6}{*}{ RENTAL } & 12V1600 G20F & 430 & 280 & 280 \\
\hline & 12V1600 G20F & 430 & 375 & 405 \\
\hline & 12V1600 G20F & 430 & 395 & 405 \\
\hline & 12V1600 G20F & 430 & 380 & 380 \\
\hline & 12V1600 G20F & 430 & 400 & 410 \\
\hline & 12V1600 G20F & 430 & 400 & 410 \\
\hline \multicolumn{3}{|c|}{ TOTAL } & 2,745 & 4,800 \\
\hline
\end{tabular}

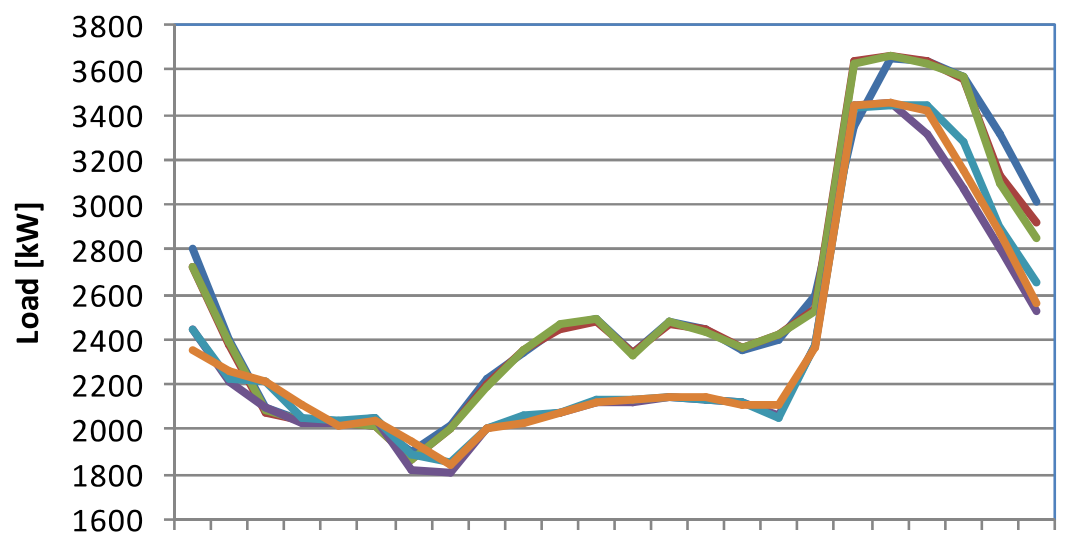

Weekday dry season

Saturday dry season

Sunday dry season

Weekday wet season

Saturday wet season

$\begin{array}{llllllllll}1 & 2 & 3 & 4 & 5 & 6 & 7 & 8 & 9 & 101112131415161718192021222324\end{array}$

Hours of one day

Figure 10. Typical load Pattern for Waingapu Grid.

Source: "Sumba Iconic Island Report - Grid Connected Electricity Generation," Hivos (KEMA), April 2011.

\subsection{Wind Potential}

Initial efforts to characterize Sumba's wind potential began as early as 1995. At least three assessments of the wind potential have been produced, beginning with one developed by NREL with funding from LAPAN (Indonesian Government Space Agency) and BPPT (Agency for the Assessment and Application Technology). The assessment combined meso-scale and meteorological 
tower based data to produce a map to highlight the areas of high wind potential in NTT Province. In addition, assessments by AWS Truepower with funding from the Dutch government and by Castlerock Consulting for ADB using the online 3Tier wind resource mapping tool have been conducted to provide further analysis of Sumba's wind potential. ${ }^{22}$

Each of these assessments indicated that Sumba's wind resources could be strong enough to be economically viable, with the highest estimated wind speeds ranging from $6.5 \mathrm{~m} / \mathrm{s}$ to $8.2 \mathrm{~m} / \mathrm{s}$ on an annual average basis. However the results of the studies are inconsistent in terms of peak wind speeds and best locations, and thus highlight the importance of collecting and analyzing robust onsite data for a reliable wind resource assessment and site selection for project build-out.

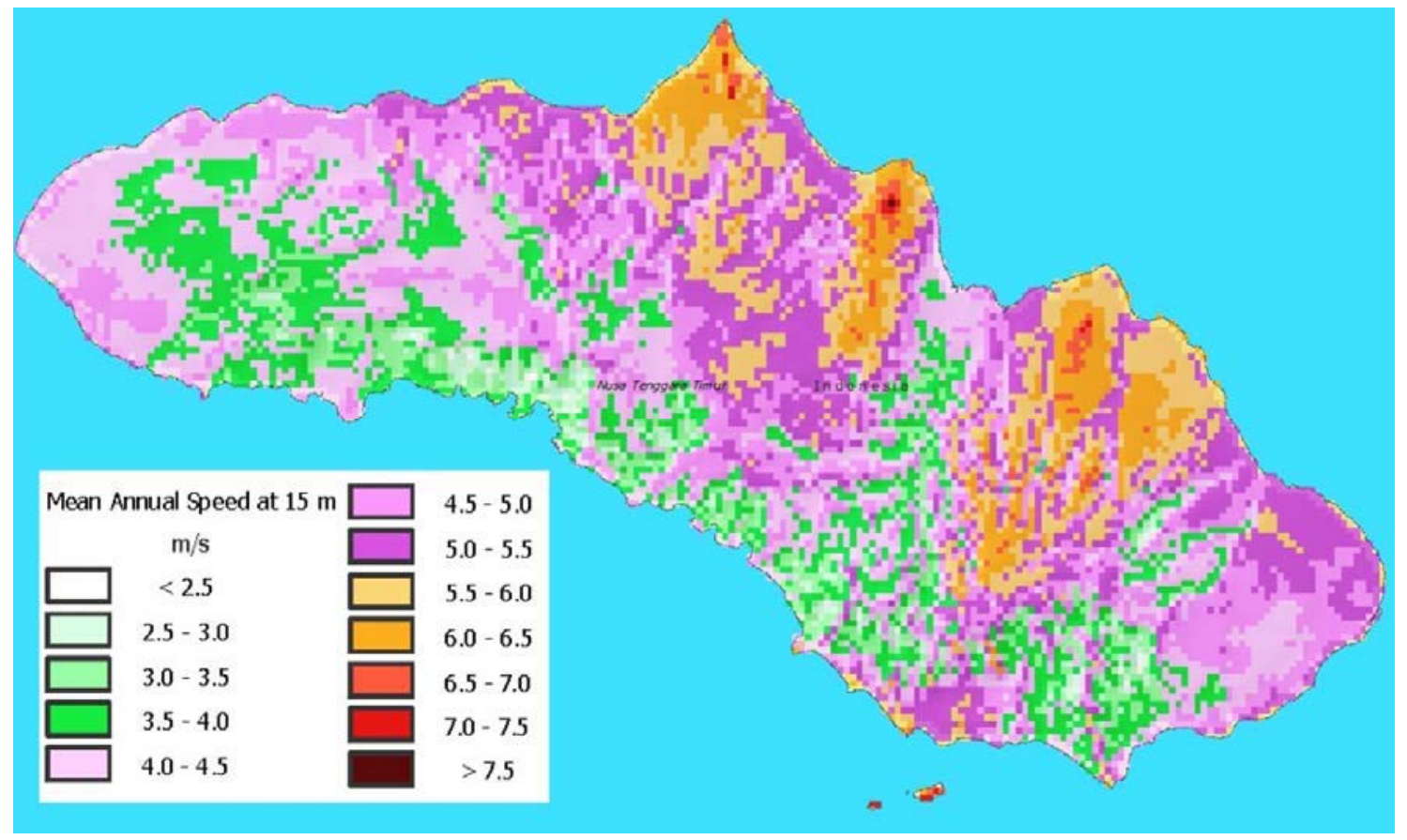

Figure 11. Wind potential map of Sumba.

Source: AWS Truepower

Accordingly, Hivos funded Winrock to perform a more detailed resource assessment of three potential wind generation sites on Sumba: Hambapreing/Tanjung Mondu, Palakahembi/Laepori, and Lawola.

While these wind sites do not necessarily have the best theoretical wind potential according to the various meso-scale assessments conducted, on-site wind measurements support the availability of good wind potential. The sites located at Hambapraing and Palakahembi are located close to PLN medium voltage grids $(20 \mathrm{kV})$ and offer relatively easy access with mostly straight tarmac roads from the harbor at Waingapu, which is important if large turbines need to be off-loaded onto the island. The third site, Lawola, is expected to have the best wind resource, but the local grid is relatively far from this site. Nevertheless, this site was included in Hivos' assessment due to its

22 “Scaling Up Renewable Energy Access in Eastern Indonesia, Inception Report,” ADB, November $18,2013$. 
proximity to the Lukat waterfall (about $2.5 \mathrm{~km}$ away), which offers the potential to combine hydro and wind resources in one system and justify the cost of grid extension, along with easing associated integration challenges and reducing the need for expensive diesel generated power.

These three sites have a total estimated potential of roughly $130 \mathrm{MW}$ to $181 \mathrm{MW}$ (Table 9).

Comparing this to the total installed diesel generator capacity of $11 \mathrm{MW}$, it is reasonable to conclude that wind energy could play a significant role in the future electrification of Sumba. In order to pin point the best locations for both resource availability and grid integration, 'micro siting' analyses based on at least one year of high quality wind data is required. Further, putting this potential renewable generation capacity in context, it is understandable that the SII long-term goal is for complete RE power for the entire island, especially when combined with hydro and PV. Achieving such an ambitious goal would also require significant energy storage and grid integration to accommodate the various intermittent renewables along with hydro.

Table 9. Potential Wind Sites and Predicted Power

\begin{tabular}{|l|c|c|c|c|}
\hline \multicolumn{1}{|c|}{ Site Name } & $\begin{array}{c}\text { Windspeed } \\
\left(\mathrm{m}^{3} / \mathrm{s}\right)\end{array}$ & $\begin{array}{c}\text { Available Area } \\
\left(\mathrm{m}^{2}\right)\end{array}$ & \multicolumn{2}{|c|}{$\begin{array}{c}\text { Predicted Power } \\
\text { (MegaWatt) }\end{array}$} \\
\hline \multirow{2}{*}{$\begin{array}{l}\text { Hambapreign/Tanjung } \\
\text { Mondu }\end{array}$} & $5.0-5.5$ & $6,362,737$ & $15.11-20.11$ & \multirow{2}{*}{$33.0-47.0$} \\
\cline { 2 - 4 } & $5.5-6.3$ & $5,663,640$ & $17.90-26.90$ & \\
\hline Palakahembi/Laepori & $5.0-5.5$ & $9,850,657$ & $23.40-31.13$ & $23.40-31.13$ \\
\hline \multirow{3}{*}{ Lawola } & $5.5-6.3$ & $10,012,499$ & $31.64-47.56$ & \multirow{3}{*}{$72.29-103.13$} \\
\cline { 2 - 4 } & $6.3-7.0$ & $1,123,763$ & $5.34-7.32$ & \\
\cline { 2 - 4 } & $8.2-9.1$ & $3,371,290$ & $35.31-48.26$ & \\
\hline
\end{tabular}

\subsubsection{Hambapraing Wind Project}

Based on the results of the assessment discussed above, which took into account wind speeds, accessibility, and proximity to the existing electrical grid among other factors, Hivos selected the site at Hambapreing/Tanjung Mondu (Figure 12) for a detailed site assessment and potential expansion into a wind generation site. 


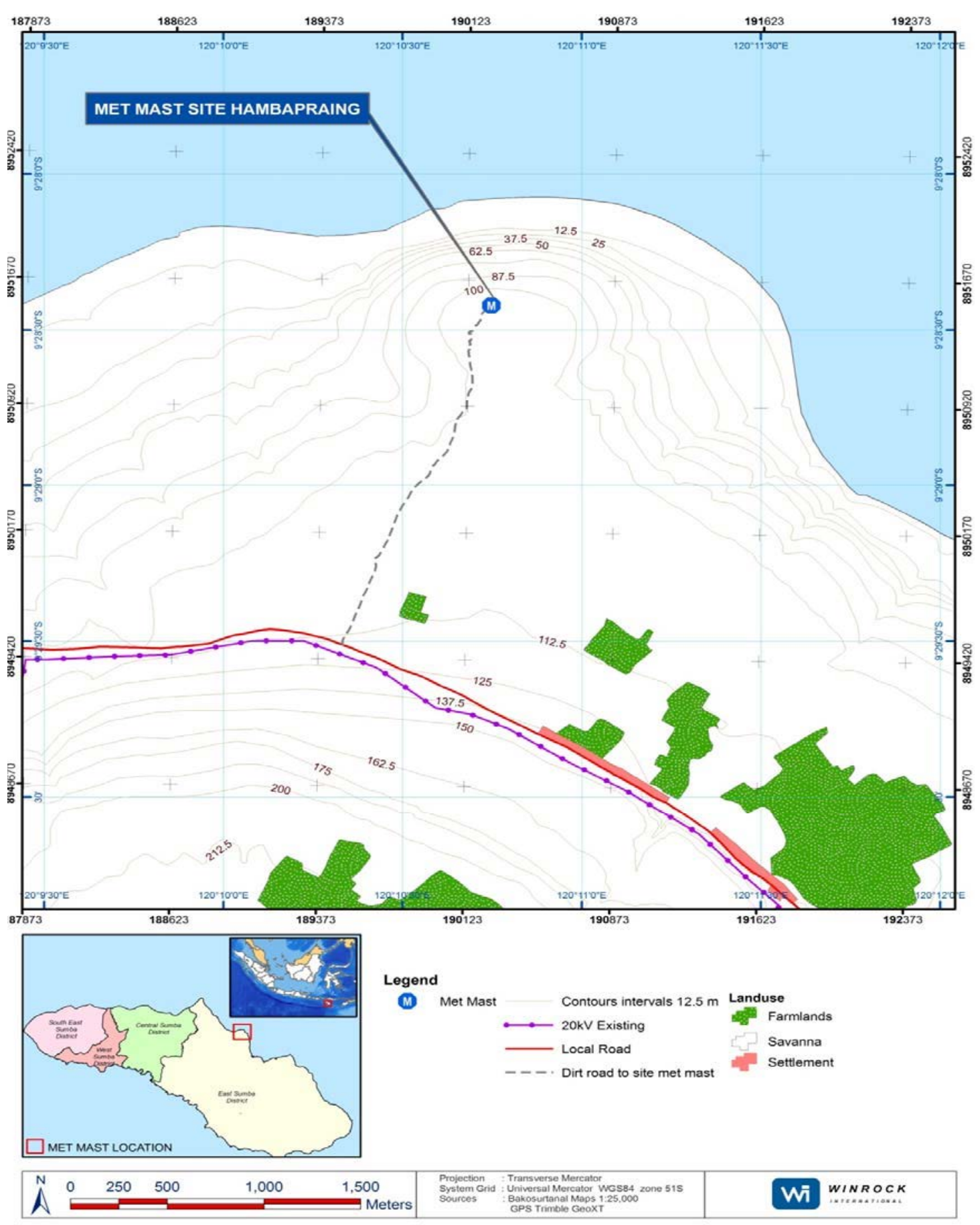

Figure 12. The Hambapraing site and surrounding area.

The Hambapraing wind project is designed for two phases. The first phase is currently ongoing, and its results will be used to determine the specific approaches and activities to be undertaken in Phase II. Phase I is focused on designing, installing, and assessing the performance of a $660 \mathrm{~kW}$ wind tower and flywheel system at the site (Figure 12). 
A $33 \mathrm{~m}$ meteorological tower was erected at the site in 2012, where it has been continually gathering wind speed data ever since. The results of the data collection conducted from July 1, 2012 to November 1, 2014 are shown in Table 10. Calculated power production distribution with the particular turbine identified (Vestas V47, $660 \mathrm{~kW}$ nameplate capacity) is shown in Figure 13. Individual annual results and other data can be found in Appendix $\mathrm{C}$.

Table 10. Summary Measurement Results (July 1, 2012 - November 1, 2014)

\begin{tabular}{|c|c|c|}
\hline \multicolumn{2}{|c|}{ Parameter } & AVG \\
\hline \multirow{4}{*}{ Average } & $M-33 m$ & 6.25 \\
\hline & $R-33 m$ & 6.26 \\
\hline & $M-23 m$ & 5.98 \\
\hline & $R-23 m$ & 6.03 \\
\hline \multirow{2}{*}{ Max. } & $M-33 m$ & 29.40 \\
\hline & $R-33 m$ & 29.20 \\
\hline Wind Direction & Degree & 121.40 \\
\hline Average Temperature & Degree C & 26.69 \\
\hline Daily Average & $\mathrm{W} / \mathrm{m} 2$ & 246.03 \\
\hline Solar Radiation & $\mathrm{Wh} / \mathrm{m} 2$ & 5936.48 \\
\hline Barometric Pressure & $m B$ & 996.86 \\
\hline
\end{tabular}

\section{Hambapraing \\ Time: 1 October 2012 Meas Height: 34.0 m \\ Vestas V47 \\ Hub Height: $65.0 \mathrm{~m}$ \\ Altude: $100 \mathrm{~m} \quad$ Temperature: $26.7^{\circ} \mathrm{C} \quad$ Conversion factor (1/7-Power Law): 1.097}

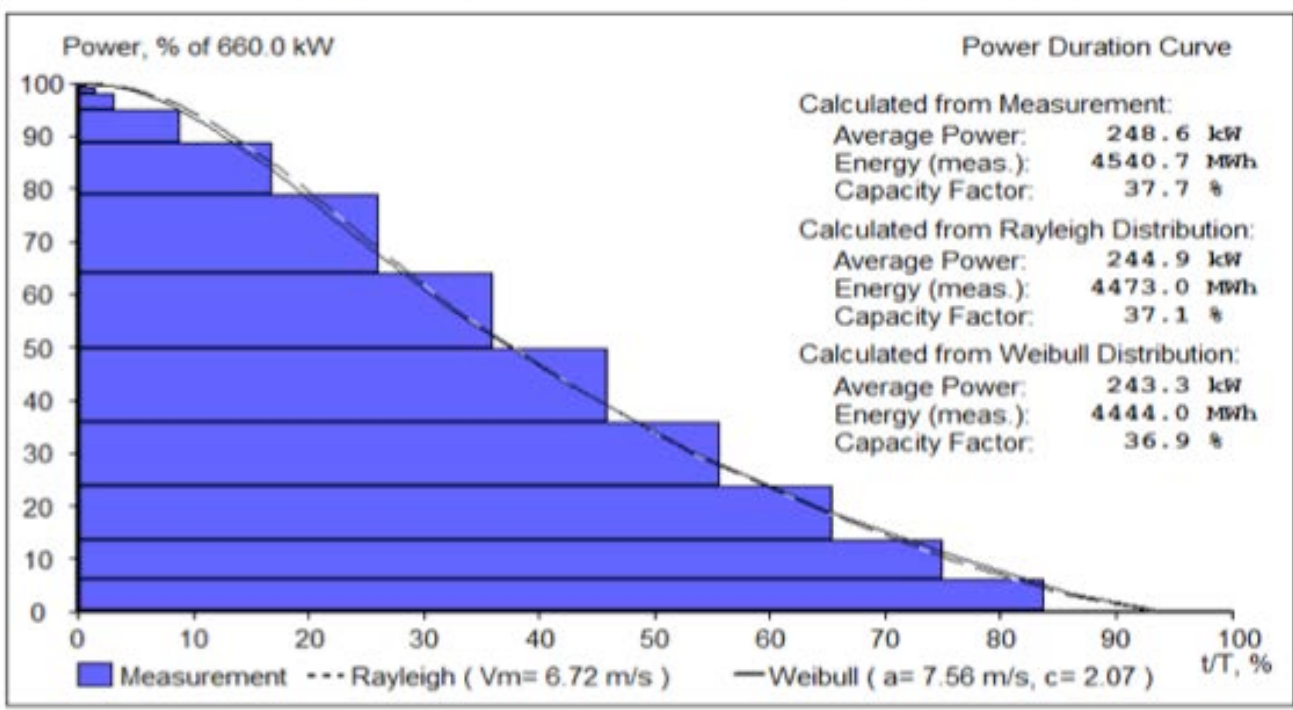

Figure 13. Energy generation estimates. 
Installation of the wind turbine and flywheel are planned for the fourth quarter of $2015 .{ }^{23}$ It will serve as a pilot project for all of SII's partners to demonstrate the viability of integrating an intermittent RE source on the grid with the aid of a flywheel to manage fluctuations. One component of the project includes training for PLN personnel to develop institutional knowledge on the operation and use of flywheels and intermittent RE sources connected to electricity grids.

Prior to the installation of the turbine, the SERIG project will support a grid integration study to verify and fine-tune initial high-level assessments to ensure appropriate system design and functionality. This study is expected to be completed by May 2015. This analysis is essential for eventual deployment of hardware and will provide a baseline metric to monitor and verify performance after installation.

The wind turbine will be owned and operated by PT Sumberdaya Sewatama, an Indonesian IPP. Hivos and Sewatama have agreed to a memorandum of understanding through which Hivos and its partners will provide support for the project's development. In addition, Hivos has signed an memorandum of understanding and obtained additional support via ministerial decree from local government offices, including the East Sumba PLN branch office, to facilitate special planning for SII projects; in particular, negotiations for non-commercial electricity pricing may be conducted outside of the standard PLN procedures.

Sewatama is in the process of negotiating the purchase price of the grid-connected electricity with PLN through such a special PPA mechanism. Sewatama has established a target electricity sales price of IDR $2,750 / \mathrm{kWh}$ based on calculations of the project's anticipated costs. To help encourage the involvement of private companies such as Sewatama, DANIDA has agreed to provide funding to help bridge the gap between Sewatama's funding requirements should PLN's final price not match the target price. This is similar to viability gap financing (VGF) discussed in the next section regarding possible incentives for private investment on Sabu Island.

Phase II of the project is planned to commence in the second quarter of 2017 after analyzing the performance of the system during Phase I. Initial plans are for Sewatama to install 3-4 MW of wind power at the Hambapraing site under an IPP agreement with PLN. Ideally, the second phase would be fully commercially funded, with no external funding required.

Discussions with various experts within the RE community in Indonesia indicate that the Government of Indonesia will release a new FiT based on avoided costs in the second quarter of 2015. A price of $\$ 0.20$ - $\$ 0.25 / \mathrm{kWh}$ for wind power has been recommended to the GOI for consideration. If a price in this range is instituted, commercial financing may be realistic, but if not, external funding sources may be needed.

\footnotetext{
23 Since the original writing of this document in late 2014, the targeted wind turbine for installation and performance assessment has changed to a $850 \mathrm{~kW}$ Vestas V52.
} 


\section{Analysis of Financial Returns for Lamandau and Sabu}

Previous sections discussed the economic viability of projects from the perspective of the utility. In this section, an analysis of potential financial performance is presented to explore the attractiveness of the proposed projects in Lamandau and Sabu to possible developers who would act as IPPs and sell the power from the project to the utility. This type of financial analysis can be a helpful complement to techno-economic analysis of RE projects by using country-specific taxation and financing policies and figures. Financial analyses are presented below for each project case. In each section, the inputs and results are described and a sensitivity analysis and discussion is presented.

For the projects in Lamandau and Sabu outlined in this report, pro forma cash flow analyses (Appendix E) were developed to determine the potential financial return to investors, using a tool developed by NREL called the System Advisor Model (SAM). SAM is software that combines energy performance models with financial models to present industry standard financial metrics. HOMER is used in this analysis to create a cost-optimized system design for each island hybrid system considering all relevant generators and system components. SAM takes the HOMER results of the RE generators and evaluates the returns as if the projects were developed and owned by an IPP selling power to PLN through a PPA. This way the financial analysis accounts for the renewable output given the complex microgrid behavior.

The results below present an intentionally conservative analysis that was conducted using no tax incentives. There are relatively complex tax incentives for RE investments in Indonesia that could improve the financial performance of these projects. These include investment tax credits, moderately accelerated depreciation (double-declining), a corporate income tax holiday for up to 10 years, and a value added tax holiday in certain cases. ${ }^{24}$ Additional research into the eligibility and application of such incentives should be conducted in subsequent studies to determine the incentivized financial returns for each project. Such level of detail is necessary for project-specific investment decisions.

Financial analyses of this kind typically involve a number of output metrics including IRR and NPV. Each has its own merits as indicators of financial performance, and each is affected by input assumptions in their own ways. IRR is a very common measure of financial performance, and represents the intrinsic rate of return of a defined series of values - in this case after-tax cash flows to equity holders. The IRR can be measured at any point in a project's life; however, it is most common to present IRR for the entire project life-in these cases 20 years. Similarly, NPV is most often calculated over the entire project life, but can also be represented cumulatively at any point in a project's life. Furthermore, NPV is a very good measure of financial performance because it represents the value a project would generate above (or below) an alternative investment with a return defined by the discount rate (often called the opportunity cost of capital). In these cases, we are considering a private developer with a target equity return of $14 \%$ where this developer could invest capital in an alternative investment and generate a 14\% return. The NPV of these projects, discounted with this rate, would show by how much additional (or lower) value these projects would return compared to the alternative investment. Both IRR and NPV account for the "time value of money," meaning, a dollar today is worth more than a dollar ten years from now. Discounted cash

\footnotetext{
${ }^{24}$ Power in Indonesia: Investment and Taxation Guide. (2013) Jakarta, Indonesia: PWC Indonesia. Accessed December 4, 2014: http://www.pwc.com/id/en/publications/assets/electricity-guide-2013.pdf. pp. 90-91.
} 
flows take into account the "time value of money" by representing values in any year as present values, thus enabling the analyst to compare returns to investments on a comparable basis.

\subsection{Lamandau Biogas Financial Return}

The analysis produced above using HOMER presented results from the perspective of the utility assuming it would purchase power through a FiT mechanism from an independent power producer. The results indicate that the utility would benefit from building a transmission line extension to the two proposed POME plants and purchasing power under the FiT rather than producing the power from diesel generators. The economic results indicate that the utility should consider building the line extension and buying the power because it will save PLN approximately $\$ 31$ million in total life-cycle savings over a 25 -year period.

The HOMER simulation presented technical results for a 3,500 kW POME digester that would produce $19.5 \mathrm{MWh}$ annually, implying a capacity factor of $64 \%$. The financial model assumes there are no degradation and no capital replacements, and accounts for routine parts replacement in the annual O\&M expenses of $\$ 439,000$. Total installed capital costs come to $\$ 8.78 \mathrm{M}$ given a cost per Watt of $\$ 2.51$. Taking a private developer's perspective, SAM was set to solve for after-tax IRR given a specified FiT of $\$ 0.1138$ for biogas projects. This FiT uses the regulated medium voltage base rate of IDR 1,050/kWh, the 1.3 multiplier for Kalimantan and an exchange rate of IDR 12,000 per USD.

The financial analysis assumes $4.4 \%$ inflation $^{25}$ over a 20 year analysis period and uses Indonesia's federal corporate tax rate of $25 \% .{ }^{26}$ The model discounts after-tax cash flows at the target equity return of $14 \%$ (on a real basis). A constant debt service coverage ratio (DSCR) of 2.0 is assumed, and the cost of project term debt is $8 \%$ for 18 years. Ninety percent of initial capital assets are depreciated on a 15-year straight line basis.

The inputs described above represent the reference case. In addition, the analysis examined an optimistic and conservative case by increasing and decreasing selected inputs by $5 \%$. A table containing all inputs for each case is shown in Appendix A. The results for each are presented below in Table 11 and cash flows for each are presented in Figure 14. The results indicate that this is a very attractive project for an investor. Furthermore, returns are relatively stable even given conservative inputs. The reference case assumptions result in an after-tax IRR of $50.2 \%$.

For the reference case, the IRR is 50\%; for the optimistic case, the IRR is undefined due to extremely heavy leveraging; and for the conservative case the IRR is $23.5 \%$. This implies that even under fairly conservative input assumptions the project still delivers a reasonable after-tax return to equity holders. Figure 15 shows the relative sensitivity of project NPV to selected inputs assuming they all vary by $+/-10 \%$. Capacity factor is clearly the most sensitive input variable followed by cost per watt, while DSCR and the interest rate are equally sensitive.

\footnotetext{
${ }^{25}$ World Bank Data: Inflation, GDP deflator (annual \%). World Bank, 2014. Accessed December 4, 2014 : http://data.worldbank.org/indicator/NY.GDP.DEFL.KD.ZG.

${ }^{26}$ Power in Indonesia: Investment and Taxation Guide. (2013) Jakarta, Indonesia: PWC Indonesia. Accessed December 4,2014: http://www.pwc.com/id/en/publications/assets/electricity-guide-2013.pdf. pp. 64.
} 
Table 11. Financial Results for Lamandau POME

\begin{tabular}{|l|r|r|r|}
\hline \multicolumn{1}{|c|}{ Metric } & \multicolumn{1}{c|}{ Reference } & \multicolumn{1}{c|}{ Optimistic } & \multicolumn{1}{c|}{ Conservative } \\
\hline Annual energy & $19,456,682 \mathrm{kWh}$ & $20,428,756 \mathrm{kWh}$ & $18,484,916 \mathrm{kWh}$ \\
\hline Capacity factor & $63.50 \%$ & $66.60 \%$ & $60.30 \%$ \\
\hline First year kWhAC/kWDC & 5,559 & 5,837 & 5,281 \\
\hline PPA price (Year 1) & $0.1138 \$ / \mathrm{kWh}$ & $0.1138 \$ / \mathrm{kWh}$ & $0.1138 \$ / \mathrm{kWh}$ \\
\hline PPA price escalation & $0.00 \%$ & $0.00 \%$ & $0.00 \%$ \\
\hline Levelized PPA price (nominal) & $0.1138 \$ / \mathrm{kWh}$ & $0.1138 \$ / \mathrm{kWh}$ & $0.1138 \$ / \mathrm{kWh}$ \\
\hline Initial cost & $\$ 8,953,560$ & $\$ 8,488,270$ & $\$ 9,398,305$ \\
\hline Equity & $\$ 1,362,494$ & $\$ 16,824$ & $\$ 2,641,428$ \\
\hline Debt & $\$ 7,591,066$ & $\$ 8,471,446$ & $\$ 6,756,878$ \\
\hline Debt fraction & $84.78 \%$ & $99.80 \%$ & $71.89 \%$ \\
\hline
\end{tabular}

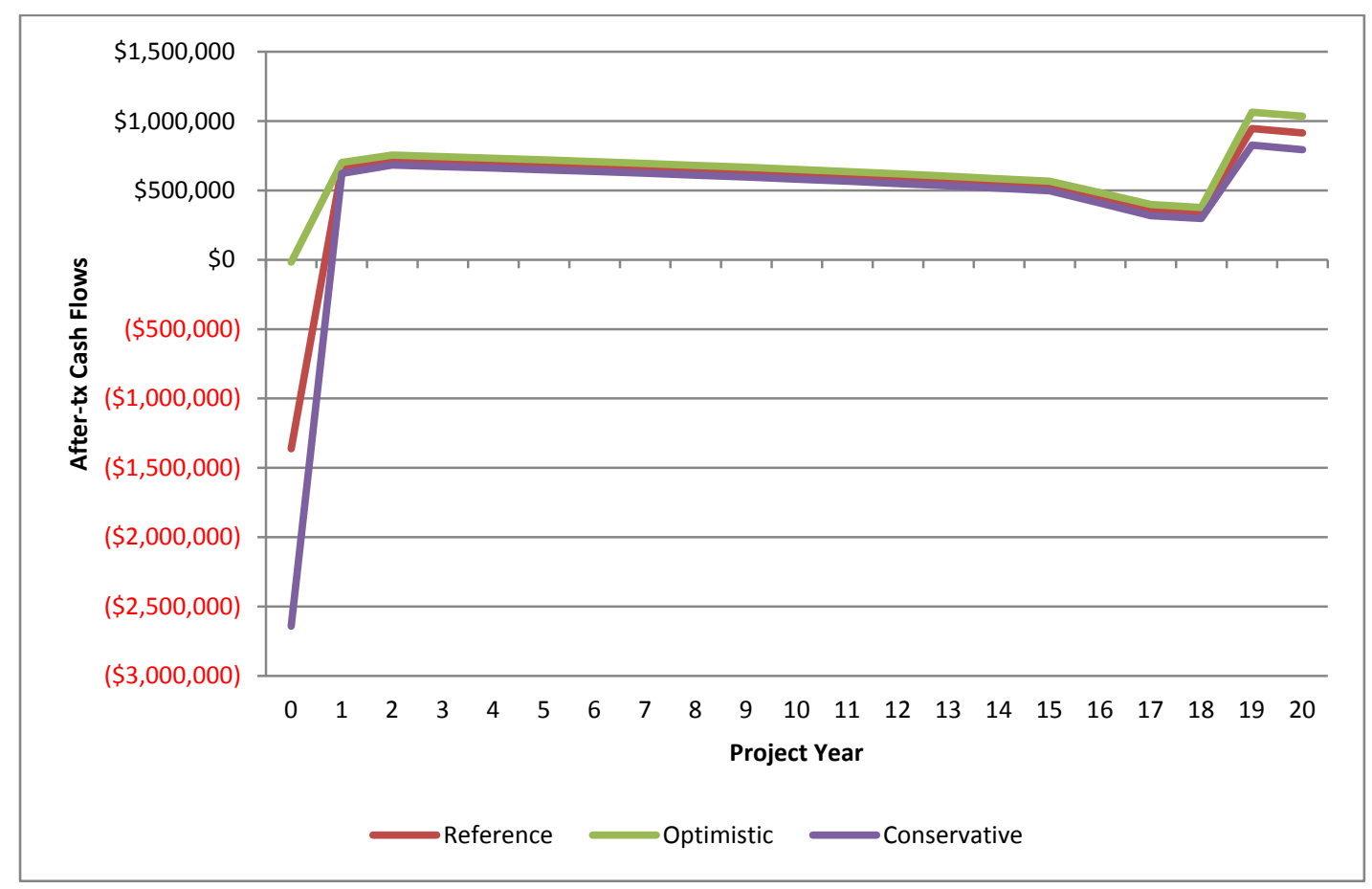

Figure 14. Project cash flows for Lamandau POME. 


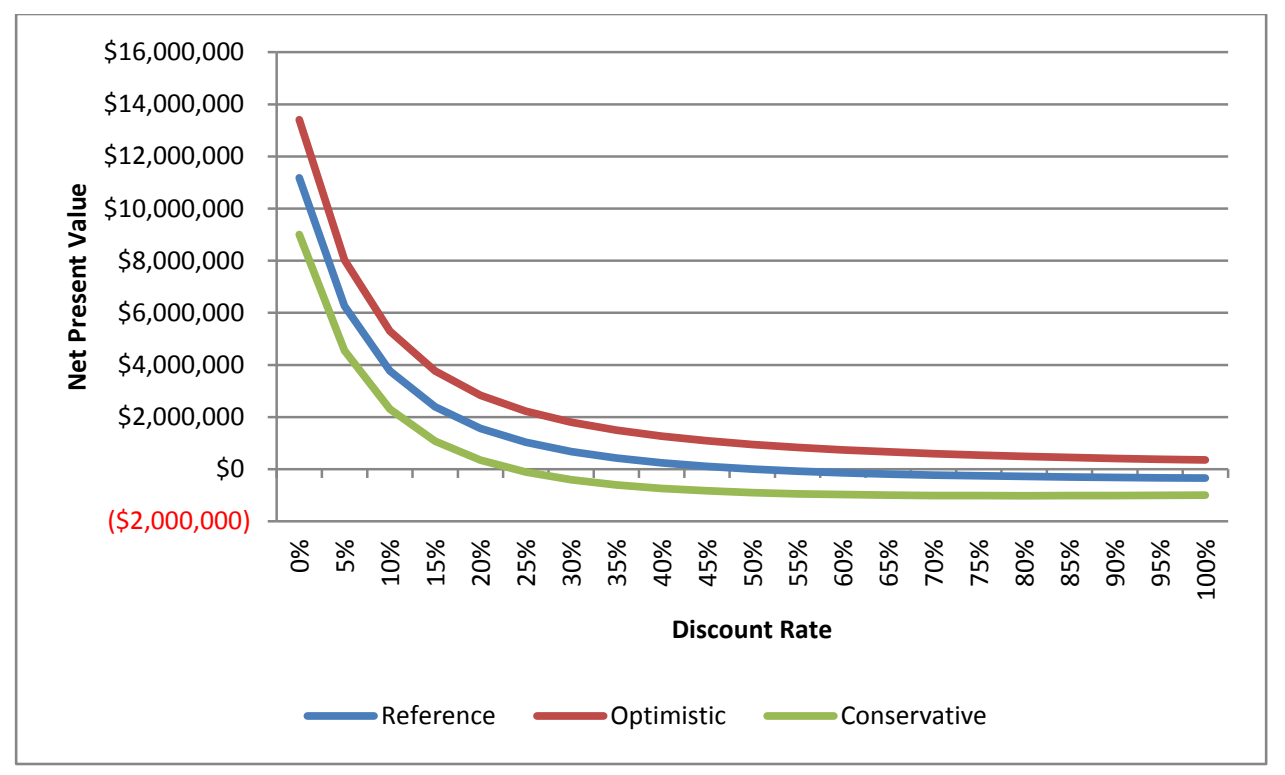

Figure 15. NPV sensitivity to discount rates for Lamandau POME.

A tornado chart (Figure 16) shows the change in a chosen output metric given a positive and negative change in selected inputs. Typically, the percentage change is identical across selected inputs so that the relative sensitivity of the output may be discerned. The color of the bars show the positive or negative change of the selected input: a red bar indicates an increase in the input value, while a gray bar indicates a decrease in the input value. The direction of the bar from the axis shows the directional change in value of the output metric. For example, if the cost per Watt increases, the NPV would go down. This is shown by a red bar on the left of the axis. Alternatively, if the capacity factor goes up, the NPV would go up. This is shown by the red bar on the right of the axis.

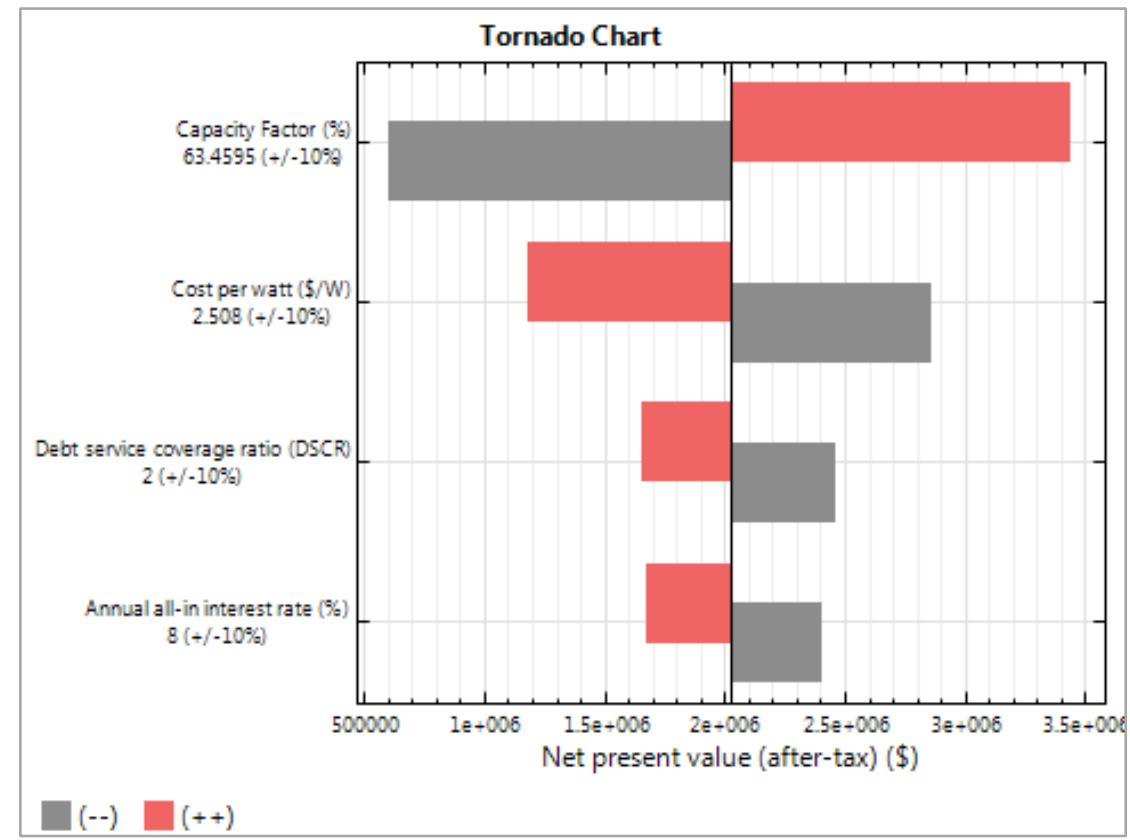

Figure 16. Tornado chart of selected inputs for Lamandau POME. 


\subsection{Sabu Island PV Financial Return}

The HOMER simulation presented technical results for a $350 \mathrm{~kW}$ PV system that would produce 715 MWh annually, implying a capacity factor of $23.32 \%$. The financial model assumes $0.8 \%$ degradation per year, an inverter replacement in year 15 at $\$ 0.1125 / \mathrm{W}$, and assumes an annual O\&M expense of $\$ 10,150$. Total installed capital costs come to $\$ 1.575 \mathrm{M}$ given a cost per watt of $\$ 4.50$. SAM was set to solve for after-tax IRR given a projected FiT of $\$ 0.20 / \mathrm{kWh}$ for PV projects. This relatively conservative FiT is below the stipulated ceiling price of $\$ 0.25$ and assumes that bids for $\mathrm{PV}$-only systems may come in under this ceiling. It is worth noting that a system of this size might not be attractive to developers. Instead, smaller projects like this could be pursued by interested NGOs or similar organizations, or several smaller projects may need to be "bundled" in order to appeal to a private developer.

The financial analysis assumes $4.4 \%$ inflation $^{27}$ over a 20 -year analysis period and uses Indonesia's federal corporate tax rate of $25 \%{ }^{28}$ The model discounts after-tax cash flows at the target equity return of $14 \%$ (on a real basis). A constant DSCR of 1.3 is assumed, and the cost of project term debt is $8 \%$ for 18 years. Ninety percent of initial capital assets are depreciated on a 15 -year straight line basis.

In addition to the reference, optimistic and conservative cases, this analysis presents a case that includes VGF. Under the VGF scenario, reference case assumptions are held while a grant value as a percentage of capital costs is increased to the point where the target after-tax IRR is achieved. For this case, a grant of $43.6 \%$ of capital costs (or $\$ 687,000$ ) would be required to deliver the target IRR of $14 \%$. The results for each are presented below in Table 12 and cash flows for each are presented in Figure 17. The results indicate that this is a fairly unattractive project for an investor due to large capital costs for PV and comparatively low capacity utilization. An after-tax IRR of $-3 \%$ and an NPV of $-\$ 585,000$ at a discount rate of $14 \%$, are not likely to entice investors unless VGF could be secured to increase after-tax returns. This analysis may be helpful in justifying the need for alternative funding to develop the proposed project. ${ }^{29}$

As in the Lamandau POME case above, undefined IRRs are solved for using zero-NPVs. Figure 19 shows the discount rate (or IRR) on the x-axis when NPV equals zero for the various Sabu PV cases. For the reference case, the after-tax IRR is $-1.5 \%$; for the optimistic case, the IRR is $1 \%$; for the conservative case the IRR is $-3 \%$; and for the VGF case the IRR is $14 \%$. Figure 20 shows the relative sensitivity of project NPV to selected inputs assuming they all vary by $+/-10 \%$. Cost per watt is clearly the most sensitive input variable followed by capacity factor. This is because PV projects are very capital intensive and all costs occur in year one of the project, meaning they are undiscounted in the NPV calculation.

\footnotetext{
${ }^{27}$ World Bank Data: Inflation, GDP deflator (annual \%). World Bank, 2014. Accessed December 4, 2014 : http://data.worldbank.org/indicator/NY.GDP.DEFL.KD.ZG.

${ }^{28}$ Power in Indonesia: Investment and Taxation Guide. (2013) Jakarta, Indonesia: PWC Indonesia. Accessed December 4, 2014: http://www.pwc.com/id/en/publications/assets/electricity-guide-2013.pdf. pp. 64.

29 Despite these results from an IPP perspective, installing PV would still be an overall cost savings as compared to the base case of diesel-only, which could be achieved by PLN if they installed, owned, and operated the PV-diesel hybrid system.
} 
Table 12. Financial Results for Sabu PV

\begin{tabular}{|l|r|r|r|r|}
\hline \multicolumn{1}{|c|}{ Metric } & \multicolumn{1}{c|}{ Reference } & Optimistic & Conservative & \multicolumn{1}{c|}{ VGF } \\
\hline Annual energy & $715,022 \mathrm{kWh}$ & $750,863 \mathrm{kWh}$ & $679,426 \mathrm{kWh}$ & $715,022 \mathrm{kWh}$ \\
\hline Capacity factor & $23.30 \%$ & $24.50 \%$ & $22.20 \%$ & $23.30 \%$ \\
\hline First year kWhAC/kWDC & 2,043 & 2,145 & 1,941 & 2,043 \\
\hline PPA price (Year 1) & $0.20 \$ / \mathrm{kWh}$ & $0.20 \$ / \mathrm{kWh}$ & $0.20 \$ / \mathrm{kWh}$ & $0.20 \$ / \mathrm{kWh}$ \\
\hline PPA price escalation & $0.00 \%$ & $0.00 \%$ & $0.00 \%$ & $0.00 \%$ \\
\hline Net present value & $(\$ 585,085)$ & $(\$ 418,769)$ & $(\$ 750,231)$ & $(\$ 42,631)$ \\
\hline Initial cost & $\$ 1,606,500$ & $\$ 1,526,462$ & $\$ 1,690,266$ & $\$ 1,606,500$ \\
\hline Equity & $\$ 750,743$ & $\$ 587,559$ & $\$ 912,894$ & $\$ 64,043$ \\
\hline Debt & $\$ 855,757$ & $\$ 938,903$ & $\$ 777,372$ & $\$ 855,757$ \\
\hline Debt fraction & $53.27 \%$ & $61.51 \%$ & $45.99 \%$ & $93.04 \%$ \\
\hline
\end{tabular}

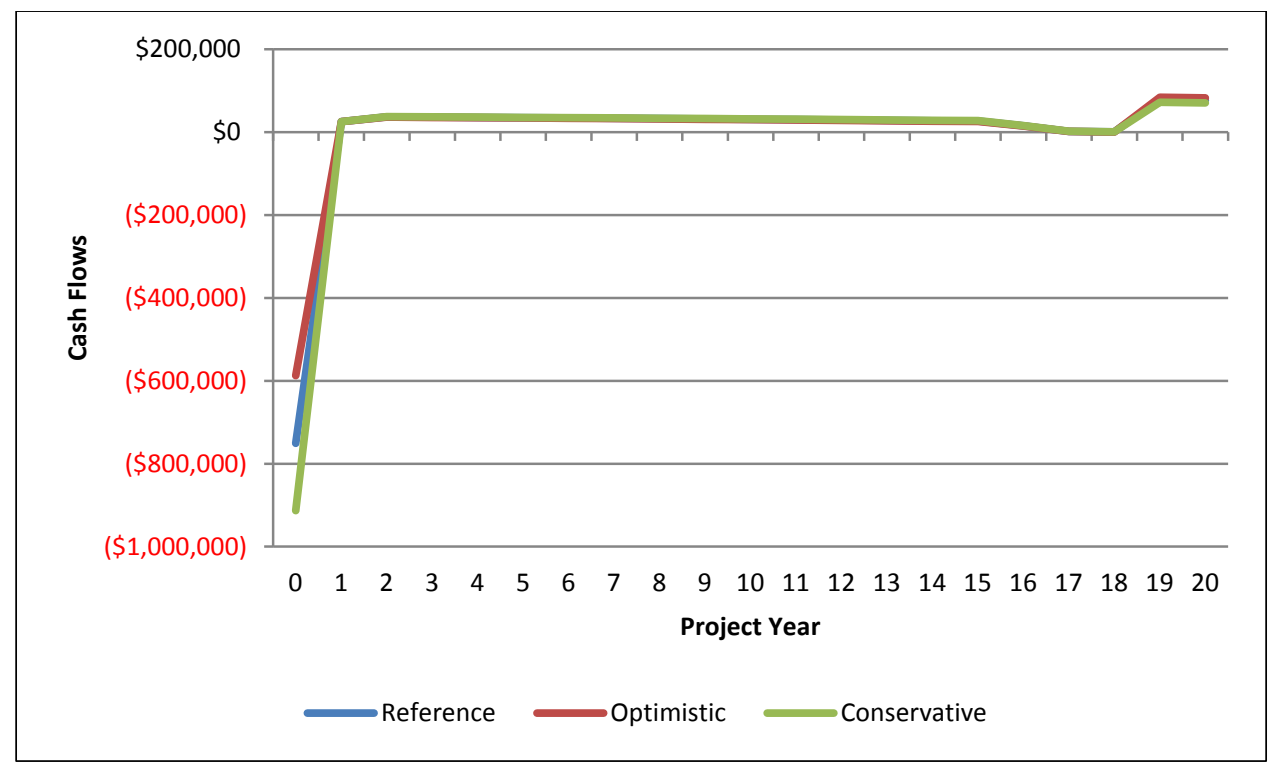

Figure 17. Project cash flows for Sabu PV. 


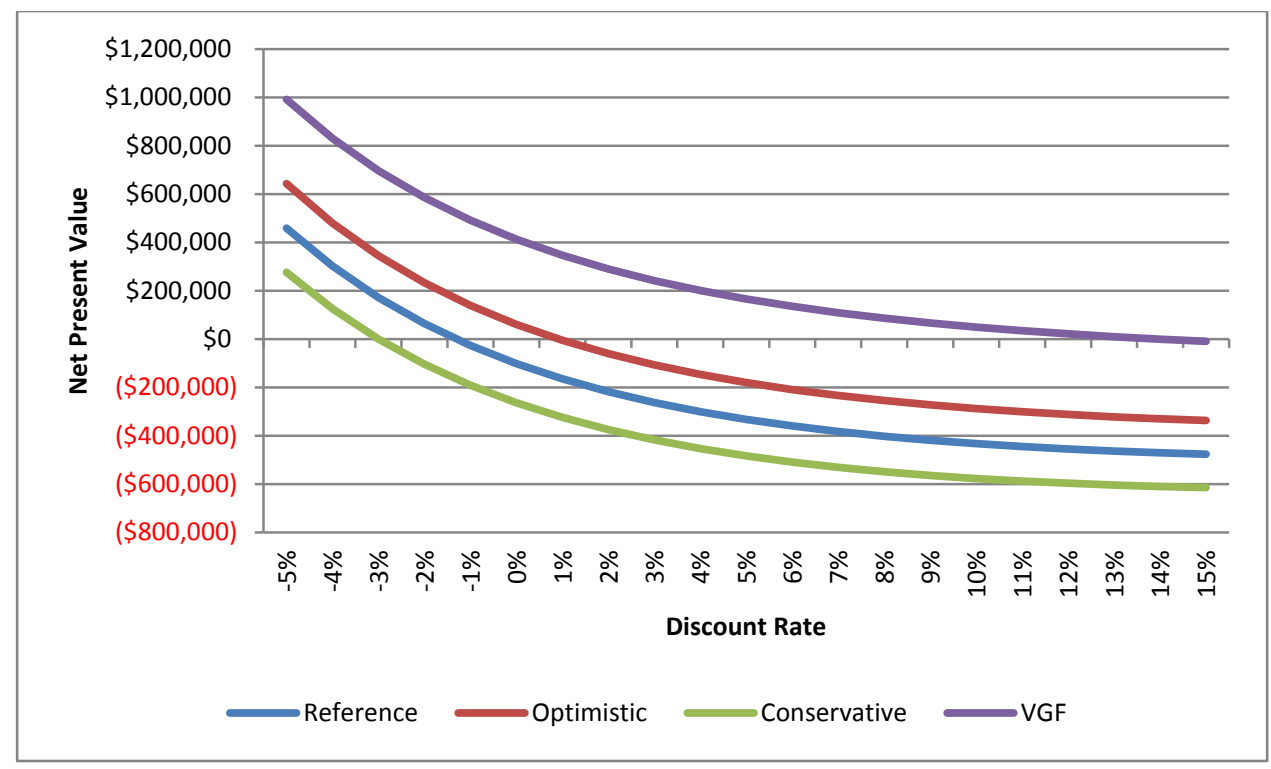

Figure 18. NPV sensitivity to discount rates for Sabu PV.

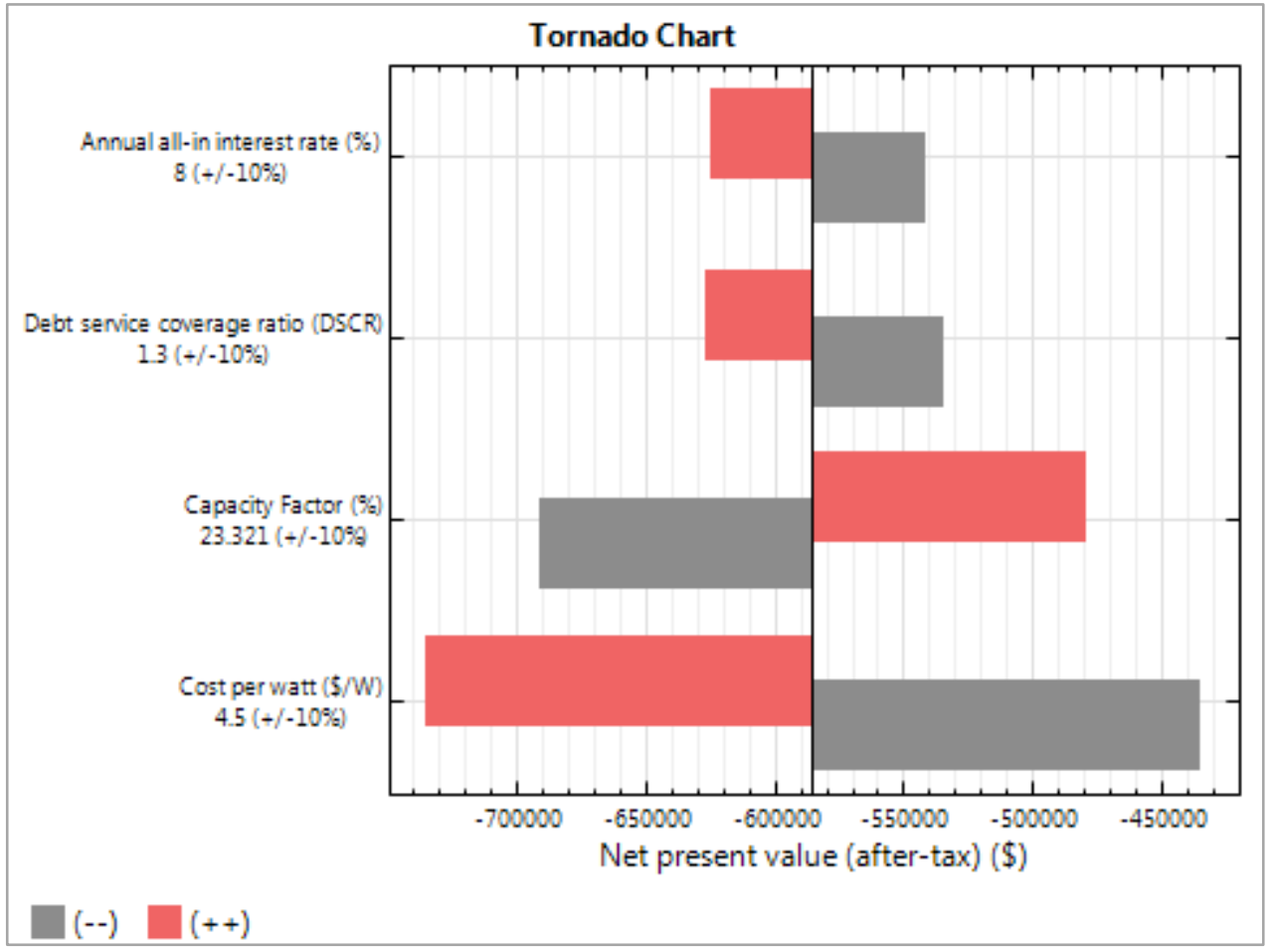

Figure 19. Tornado chart of selected inputs for Sabu PV. 


\subsection{Sabu Island PV-Battery Financial Return}

The HOMER simulation presented technical results for a 1,000 kW hybrid PV-battery system that would produce 2,043 MWh annually, implying a capacity factor of $23.32 \%$. The financial model assumes $0.8 \%$ degradation per year, an inverter replacement in year 15 at $\$ 0.1125 / \mathrm{W}$, and battery replacement in year 16 at $\$ 0.2827 / \mathrm{W}$. The model assumes an annual O\&M expense of $\$ 10,150$, and total installed capital costs of $\$ 4.77 \mathrm{M}$ given a cost per watt of $\$ 4.50$ and battery capital costs of $\$ 270,000$. SAM was set to solve for after-tax IRR given a projected FiT of $\$ 0.25 / \mathrm{kWh}$ for a hybrid PV-battery project.

The financial analysis assumes $4.4 \%$ inflation $^{30}$ over a 20 -year analysis period and uses Indonesia's federal corporate tax rate of $25 \%{ }^{31}$ The model discounts after-tax cash flows at the target equity return of $14 \%$ (on a real basis). A constant DSCR of 1.3 is assumed, and the cost of project term debt is $8 \%$ for 18 years. Ninety percent of initial capital assets are depreciated on a 15 -year straight line basis.

As in the analyses above, four different cases were considered: reference, optimistic, conservative, and VGF scenarios. For this project, a grant of $36 \%$ of capital costs (or $\$ 1.717 \mathrm{M}$ ) would be required to deliver the target IRR of 14\%. The results for each are presented below in Table 13 and cash flows for each are presented in Figure 20. The results indicate that this is a fairly unattractive project for an investor due to large capital costs for PV and comparatively low capacity factor utilization. An after-tax IRR of $0.2 \%$ and an NPV of $(\$ 1,489,000)$ at a discount rate of $14 \%$ are not likely to entice investors unless VGF could be secured to increase after-tax returns.

Table 13. Financial Results for Sabu Hybrid PV-Battery

\begin{tabular}{|l|r|r|r|r|}
\hline \multicolumn{1}{|c|}{ Metric } & \multicolumn{1}{c|}{ Reference } & Optimistic & Conservative & \multicolumn{1}{c|}{ VGF } \\
\hline Annual energy & $2,043,007 \mathrm{kWh}$ & $2,145,324 \mathrm{kWh}$ & $1,941,216 \mathrm{kWh}$ & $2,043,007 \mathrm{kWh}$ \\
\hline Capacity factor & $23.30 \%$ & $24.50 \%$ & $22.20 \%$ & $23.30 \%$ \\
\hline First year kWhAC/kWDC & 2,043 & 2,145 & 1,941 & 2,043 \\
\hline PPA price (Year 1) & $0.25 \$ / \mathrm{kWh}$ & $0.25 \$ / \mathrm{kWh}$ & $0.25 \$ / \mathrm{kWh}$ & $0.25 \$ / \mathrm{kWh}$ \\
\hline PPA price escalation & $0.00 \%$ & $0.00 \%$ & $0.00 \%$ & $0.00 \%$ \\
\hline Levelized PPA price (nominal) & $0.2517 \$ / \mathrm{kWh}$ & $0.2517 \$ / \mathrm{kWh}$ & $0.2517 \$ / \mathrm{kWh}$ & $0.2517 \$ / \mathrm{kWh}$ \\
\hline Initial cost & $\$ 4,865,400$ & $\$ 4,636,450$ & $\$ 5,105,000$ & $\$ 4,865,400$ \\
\hline Equity & $\$ 1,976,412$ & $\$ 1,446,200$ & $\$ 2,500,282$ & $\$ 259,212$ \\
\hline Debt & $\$ 2,888,989$ & $\$ 3,190,250$ & $\$ 2,604,718$ & $\$ 2,888,989$ \\
\hline Debt fraction & $59.38 \%$ & $68.81 \%$ & $51.02 \%$ & $91.77 \%$ \\
\hline
\end{tabular}

\footnotetext{
${ }^{30}$ World Bank Data: Inflation, GDP deflator (annual \%). World Bank, 2014. Accessed December 4, 2014 : http://data.worldbank.org/indicator/NY.GDP.DEFL.KD.ZG.

${ }^{31}$ Power in Indonesia: Investment and Taxation Guide. (2013) Jakarta, Indonesia: PWC Indonesia. Accessed December 4,2014: http://www.pwc.com/id/en/publications/assets/electricity-guide-2013.pdf. pp. 64.
} 


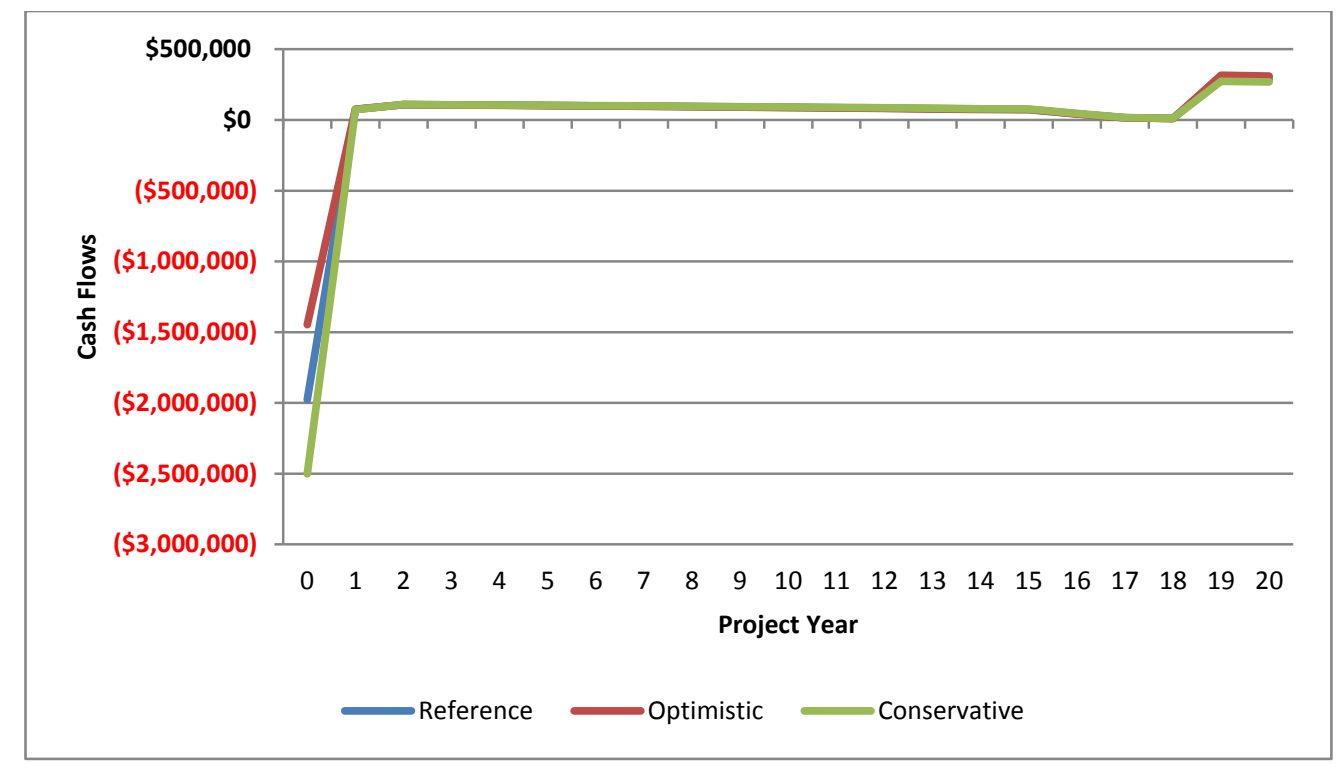

Figure 20. Project Cash Flows for Sabu Hybrid PV-Battery

As in the projects above, undefined IRRs are solved for using zero-NPVs. Figure 21 shows the discount rate (or IRR) on the x-axis when NPV equals zero for the various Sabu hybrid PV-battery cases. For the reference case, the after-tax IRR is $0.2 \%$; for the optimistic case, the IRR is $3.2 \%$; for the conservative case the IRR is $-1.9 \%$; and for the VGF case the IRR is $13.95 \%$. The results of the sensitivity analysis shown in the tornado chart in Figure 22 depict the same sensitivities as the PVonly case presented above: high capital costs and relatively low capacity utilization hurt the financial returns of PV projects.

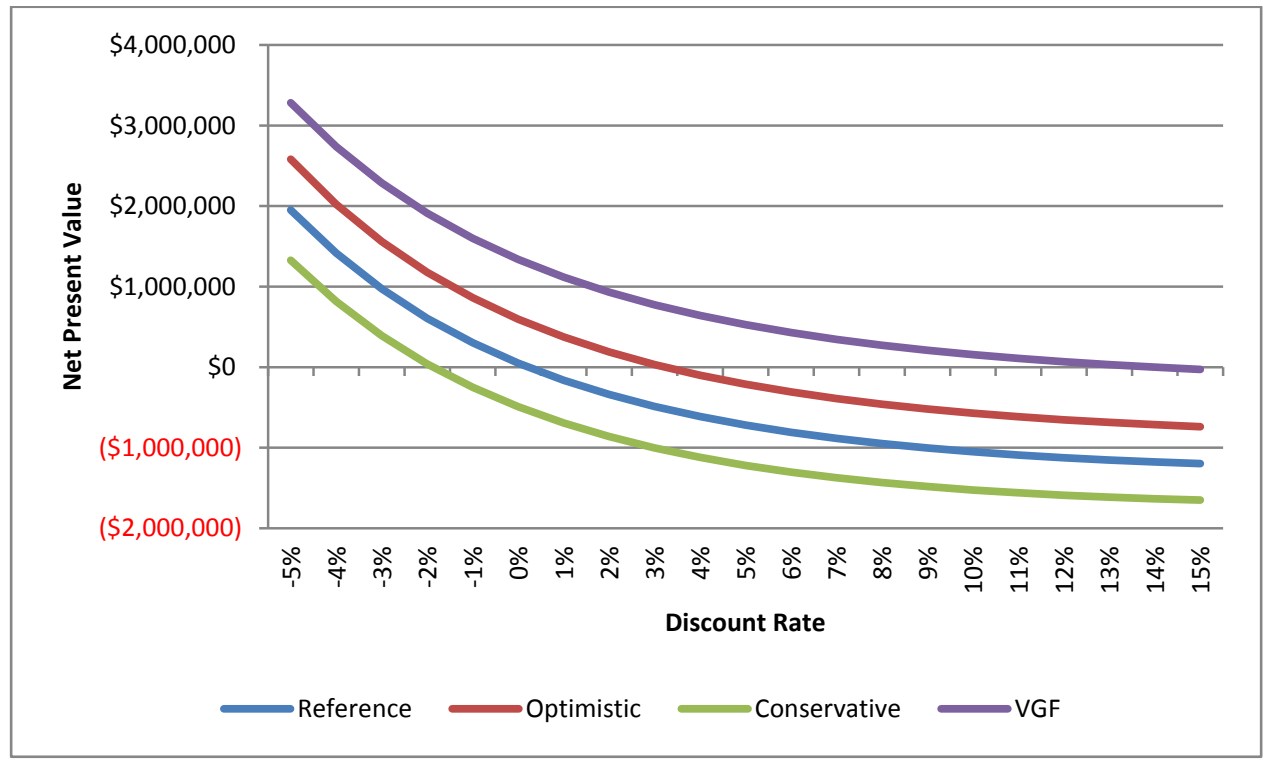

Figure 21. NPV sensitivity to discount rates for Sabu hybrid PV-battery. 


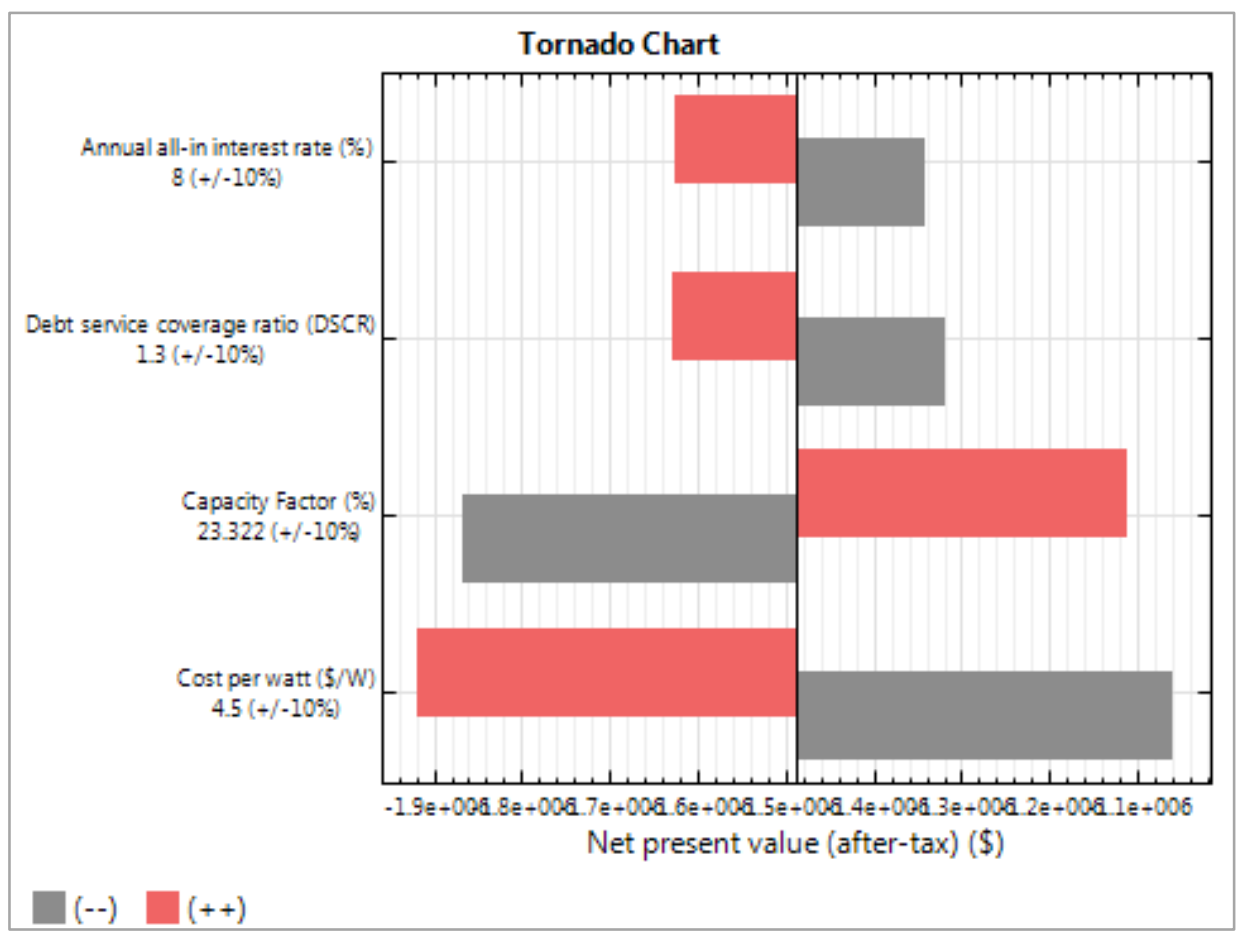

Figure 22. Tornado chart of selected inputs for Sabu hybrid PV-battery.

\subsection{An Alternative Perspective}

So far, this analysis has examined the financial returns from an IPP perspective. Recognizing the possibility that PLN could choose to develop a project like this, the single-variable sensitivity analysis below presents the sensitivity of the project NPV to PLN at different PPA prices. In this case, PPA price can be used as a proxy for opportunity cost of electricity generation (for marginal generation cost, or levelized cost depending on the alternative scenario considered). If, for example, PLN had to weigh a PV investment against building new diesel capacity, the generation cost of $\$ 0.39 / \mathrm{kWh}$ for new diesel could be used. ${ }^{32}$ In that case, PLN would realize an NPV of $\$ 475,000$. If, on the other hand, the PV system would offset existing diesel at a marginal generation cost of $\$ 0.30 / \mathrm{kWh}$, the NPV of that investment would be $-\$ 55,000$. These NPV values are calculated using the target equity return of $14 \%$ for the discount rate. This is likely very high compared to a discount rate PLN might use, which would therefore improve the results significantly. This type of analysis is useful for comparing the attractiveness of this type of investment against a wide variety of possible alternate investments.

\footnotetext{
${ }^{32}$ Statistik PLN 2013, page 62 (http://www.pln.co.id/blog/laporan-statistik/)
} 


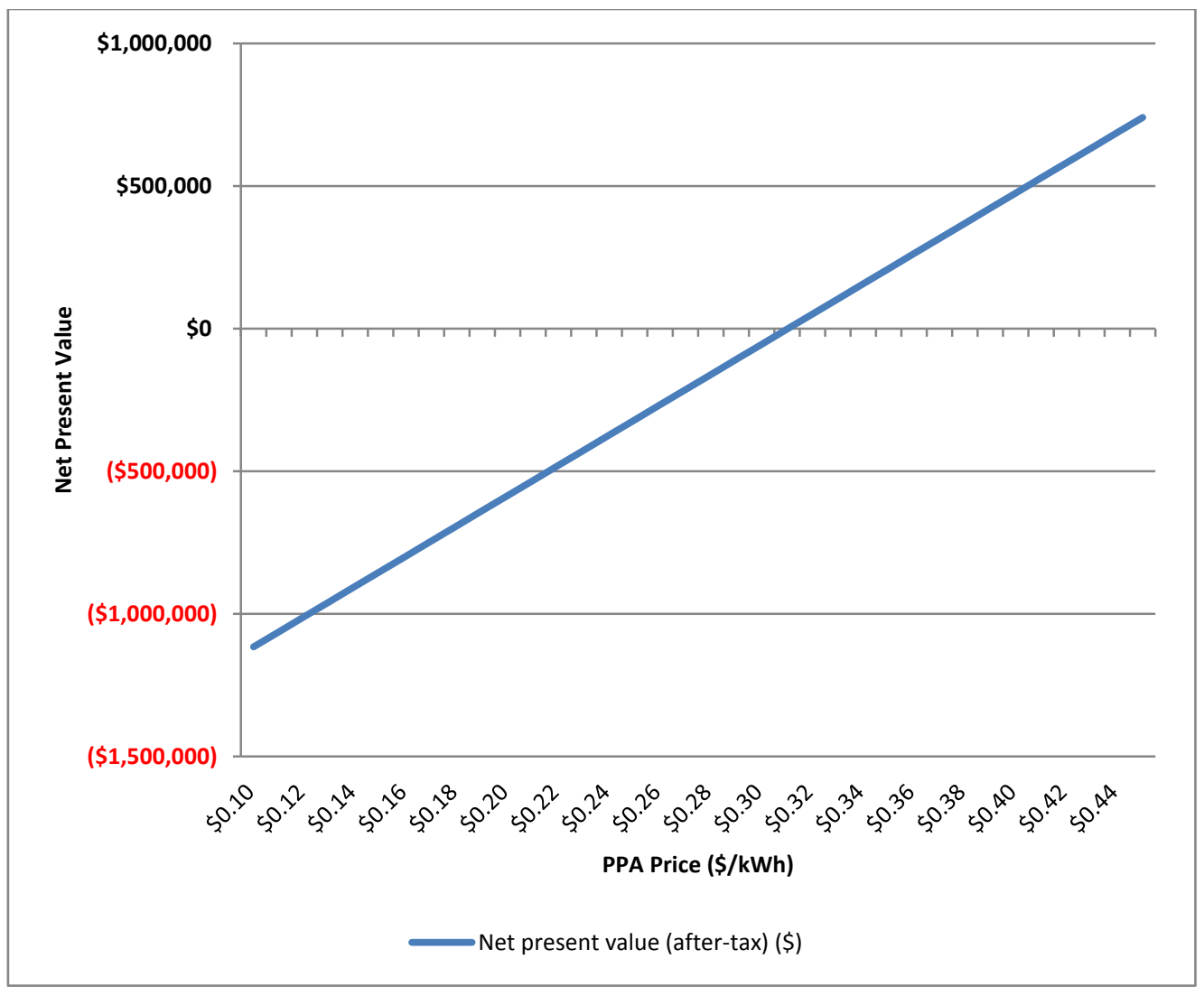

Figure 23. Sensitivity of NPV to PPA price for Sabu PV. 


\section{Conclusions and Next Steps}

The SERIG team selected three different locations for enhanced analysis: Lamandau, Sabu, and Sumba. Each site has unique RE resource characteristics, existing infrastructure, load profiles, and institutional considerations. These three sites represent a wide range of technologies and investment perspectives that, collectively, can provide important best practice demonstrations for replication and regional and national impact.

The three selected SERIG sites all show, to varying degrees, technical and economic feasibility from enhanced RE and energy efficiency investment to displace diesel generation. Though each project will require a different mix of technologies and confront unique, site-specific challenges, there are important commonalities and similarities that provide a general project development framework for broad deployment.

From a technical perspective, integrating large amounts of intermittent RE resources such as wind and solar on isolated diesel microgrids poses a significant challenge. The techno-economic feasibility analyses performed to date identify an optimum hybrid technology mix for each project given available data such as loads and load growth, locally available renewable resources, and existing diesel genset configuration. This report takes the techno-economic analyses one step further by feeding these outputs into conventional assessments of financial return that would typically be conducted by private investors.

Small individual projects often do not receive this level of detailed evaluation by private investors because such assessments are data- and time-intensive, and hence, costly. This report is an attempt to reduce these and associated start-up and transaction costs, and accelerate the development process, by defining optimum investment prospects in terms of size and type of project. Along with financial analysis, the SERIG team aims to facilitate project development through stakeholder outreach and institutional cooperation, i.e., bringing all the necessary entities together to identify opportunities and unmet needs.

All three locations are experiencing significant load growth. This adds complexity to planning for new system hardware but also provides incentive to properly scale and integrate a RE-diesel hybrid system to maximize diesel displacement. Consistent with conventional wisdom within the energy industry, the assessments conducted here show that smaller and more variable, less dispatchable RE hybrid systems, such as PV-diesel on Sabu Island, are less economically attractive than, for example, biogas from POME in Lamandau. Sumba Island, which is the largest of the three sites, has several different RE opportunities that are in various stages of development, with dispatchable hydro currently the most prominent and receiving the most investment, but recent assessments show a substantial amount of windpower potential. Integrating windpower into Sumba's grid is the focus of our SERIG initiative on that island.

Table 14 summarizes the financial analysis for a 3.5 MWe POME biogas project in Lamandau, a 350 kW PV system with no batteries on Sabu Island, and a 1 MW PV system with $461 \mathrm{kWh}$ of lead acid batteries on Sabu Island. For brevity, only the base case assumptions for all three projects are presented here, though additional sensitivity analysis was performed and presented in Section 6.4. It should be noted that capacity factor and cost-effectiveness of installation, represented by $\$ /$ Watt, 
were identified as the variables that most impact the ultimate attractiveness of these projects for private investment.

Table 14. Financial Analysis Summary of Three Projects with Base Case Assumptions

\begin{tabular}{|l|l|l|l|l|l|c|}
\hline $\begin{array}{c}\text { Proposed Location } \\
\text { and System }\end{array}$ & $\begin{array}{c}\text { FiT } \\
(\$ / \mathrm{kWh})\end{array}$ & NPV & $\begin{array}{c}\text { IRR } \\
\text { (base } \\
\text { case) }\end{array}$ & $\begin{array}{c}\text { Capital } \\
\text { Cost }\end{array}$ & $\begin{array}{c}\text { LCOE } \\
(\$ / \mathrm{kWh})\end{array}$ & $\begin{array}{c}\text { VGF for } \\
14 \% \text { IRR }\end{array}$ \\
\hline $\begin{array}{l}\text { Lamandau - POME } \\
\text { biogas, 3.5 MWe }\end{array}$ & $\$ 0.1138$ & $\$ 2.021 \mathrm{M}$ & $50.2 \%$ & $\$ 8.78 \mathrm{M}$ & $\$ 0.0106$ & --- \\
\hline $\begin{array}{l}\text { Sabu - 350 kW, no } \\
\text { batteries }\end{array}$ & $\$ 0.20$ & $(\$ 585,000)$ & $-3 \%$ & $\$ 1.575 \mathrm{M}$ & $\$ 0.3097$ & $\$ 687,000$ \\
\hline $\begin{array}{l}\text { Sabu - 1,000 kW, } \\
\text { with 461 kWh } \\
\text { batteries }\end{array}$ & $\$ 0.25$ & $(\$ 1.5 \mathrm{M})$ & $0.2 \%$ & $\$ 4.77 \mathrm{M}$ & $\$ 0.3047$ & $\$ 1.489 \mathrm{M}$ \\
\hline
\end{tabular}

The Lamandau POME biogas project is by far the largest and potentially most lucrative investment of the three proposed projects (this does not include Sumba, which did not receive the same financial analysis, and is discussed briefly below). The Lamandau project is most attractive for several reasons, including, as previously mentioned, the economy of scale afforded by the larger size of the project and the dispatchability of biogas as a direct substitute for diesel generation. Biogas in a tank is essentially stored energy, whereas storage for PV must be accomplished with batteries or a related technology, which is much more expensive, and PV production in general (during the day) does not align well with peak loads (at night).

It should also be noted that the FiT on Sabu for PV with batteries is assumed to be higher $(\$ 0.25 / \mathrm{kWh})$ than PV without batteries $(\$ 0.20 / \mathrm{kWh})$. This is because the capital cost and the value of the PV power with batteries is also higher; the batteries provide grid stabilizing services (essentially, ramp rate reductions) and some peak time shifting. In other words, some of the PV power generated during the day is stored until the sun goes down when peak demand ramps up. This is limited by the size of the battery bank recommended by the HOMER analysis.

The VGF column in Table 14 represents the amount of capital expense that would need to be covered by outside funding, such as a grant, to provide for the targeted $14 \%$ IRR. The IRR can be viewed as profit that a private investor would need to realize in order to be willing to invest in such a project. POME in Lamandau does not require VGF, though both configurations of PV on Sabu would. Nonetheless, PV on Sabu, with or without batteries, is cost-effective in comparison to diesel generation under a broad range of assumptions. This conclusion points to a potential alternative investment approach for Sabu Island, specifically, not a private investor looking for a 14\% return, but rather, PLN looking to cost-effectively displace diesel fuel. Further, this points to the potential role of outside funding agencies such as MCA-I or DANIDA to provide gap funding in the most (financially) challenging circumstances. In other words, private investment should not need much (or any) additional encouragement in Lamandau; however in Sabu, a "business case" model may require an alternative mix of private and public investment and a focus on cost savings from diesel displacement as compared to an internal rate of return. 
While this will be addressed in more detail in the final SERIG report, a nation-wide FiT, even with regional multipliers, may not accurately represent either the cost of developing RE in certain places or the avoided cost of diesel generation in those locations. With the FiT in Sabu as a case in point, the analysis presented here results in a negative NPV under most assumptions and system configurations. However, if the FiT is altered, which may be justified if the cost of diesel generated electricity in this remote, small system is on the higher end of estimated prices (perhaps as much as $\$ 0.60 / \mathrm{kWh}$ ), the financial analysis would show a more attractive investment opportunity and/or a smaller VGF needed. At a minimum, more precise information on site-specific generation costs would be helpful to better understand the opportunity presented by RE hybrid systems resulting in diesel fuel displacement. This could be useful to private investors, PLN, and outside funders for decision-making, especially in high cost remote locations.

On a related note, though not represented in Table 14, the current state of financial analysis for Sumba (not conducted by the SERIG team) has identified a target FiT of IDR 2,750/kWh $(\$ 0.2292 / \mathrm{kWh})$ for viable private industry investment in a proposed wind and flywheel project. Actual FiT and related terms of agreement for the proposed wind project on Sumba are still pending, and depending on the outcome, VGF or a similar funding vehicle may be required in this case as well. Fortunately, DANIDA has expressed interest in providing such a vehicle if necessary.

The unique situation in Sumba, which includes substantial RE resource availability and numerous public and private entities involved in project development, require detailed planning and coordination, both institutionally and technically. SERIG's contribution to grid stability and integration assessments, beginning with a single wind turbine and flywheel, will help to lay the foundation for larger, high penetration RE-diesel hybrid systems in Sumba. Ultimately integrating this single wind turbine with other wind power across the island, along with short-term storage such as flywheels and dispatchable RE such as hydro and possibly biogas, has potential for substantial displacement of diesel generation on Sumba. If successful, Sumba will be a regional, national, and perhaps even international role model and best practice demonstration. For large-scale replication, it must be clearly shown that very high RE contributions to isolated diesel grids are not only technically feasible but cost-effective as well.

Regarding next steps for all of the projects considered here, to more fully assess the impacts of recommended hybrid technology configurations on existing infrastructure, additional grid stability and integration studies need to be conducted. This requires sophisticated analysis and understanding of specific systems to address such issues that emerge from high instantaneous contribution of intermittent renewables into diesel-electric systems. Detailed economic analysis is also necessary to determine appropriate investment vehicles and opportunities. Without incorporating the results of more detailed studies, the new system will likely not perform as originally predicted — resulting in less favorable project economics and possibly even system failure.

To underscore this, for example, the sensitivity analyses above showed that capacity factor is the single largest variable to impact NPV or IRR in the Lamandau biogas project; capacity factor is the second largest factor in Sabu PV, with or without batteries. Capacity factor is directly influenced by proper system design and integration of RE into the diesel grid. Hence, without a full understanding of how the RE production will impact diesel performance, the economic value of the RE will be miscalculated, and project investment will be under-utilized. 
Along with additional grid integration studies, site- and community-specific project sustainability strategies will be required for long-term success of these projects. This includes a business plan, an ownership structure, payment mechanism, an identified "project champion" and viable business entity to conduct ongoing operations, maintenance, troubleshooting, bill collection, and community education and outreach. In some cases a private investor with very clear and aggressive financial incentives may be the appropriate entity, and in other cases it may be PLN or local government or a community-based NGO or business cooperative. Human capacity building and training of local people are also essential elements of a long-term sustainability strategy and need to be incorporated in the selected projects. In the Sumba wind project for example, it has been identified that installing and integrating a flywheel into PLN's grid will require specific training and planning to maximize diesel displacement and system performance. Though a private developer may take the lead on this project, PLN will be receiving training and possibly house the flywheel in the diesel powerhouse for optimized system integration.

Identifying available and appropriate financing is another necessary next step. It is possible that each of the three individual projects will require substantially different financing strategies, or it may be possible to bundle two or more of the projects to make a more attractive opportunity for a developer. It may also be necessary to combine the funding of these projects with a donor and/or government agency to provide VGF or a similar incentive. The financial challenges associated with PV installation on Sabu Island may point toward PLN as the appropriate project leader and beneficiary. Fortunately, there are several national and international public and private financing entities that are aware of such opportunities and support RE development in Indonesia, including MCA-I, ADB, DANIDA, the World Bank, and private equity investors.

Finally, it should be noted that these analyses and project-specific recommendations are being conducted under existing conditions, specifically incentives and policies that are now in place. Current trends such as global fossil fuel price declines, combined with reduction in fossil fuel price subsidies in Indonesia, will likely impact financial viability and projections of specific projects, along with distribution of benefits and costs. The next and final SERIG report will aim to address these issues and examine incentives, policies, and lessons learned from the selected SERIG projects and other locations to leverage opportunities and offer national replication strategies for broader, accelerated impact. 


\section{Appendices}

\section{Appendix A: Production Cost Modeling Inputs}

Table A-1. Lamandau

\begin{tabular}{|c|c|c|c|c|}
\hline System Specs and Load & Reference & Optimistic & Conservative & Units \\
\hline \multirow{5}{*}{$\begin{array}{l}\text { Capacity } \\
\text { Load served } \\
\text { Capacity factor } \\
\text { Generation } \\
\text { Degradation }\end{array}$} & 3,500 & & & $\mathrm{~kW}$ \\
\hline & $19,456,678$ & & & $\mathrm{kWh} / \mathrm{yr}$ \\
\hline & $63.46 \%$ & $66.63 \%$ & $60.29 \%$ & $\mathrm{CF}$ \\
\hline & $19,456,683$ & & & ann kWh \\
\hline & 0 & & & $\% /$ year \\
\hline System Costs & Reference & Optimistic & Conservative & Units \\
\hline \multirow{3}{*}{$\begin{array}{l}\text { Capital Cost } \\
\$ / W \\
\text { O\&M/yr }\end{array}$} & $\$ 8,778,000$ & & & USD \\
\hline & $\$ 2.51$ & $\$ 2.38$ & $\$ 2.63$ & USD/W \\
\hline & $\$ 438,900$ & $\$ 416,955$ & $\$ 460,845$ & USD/yr \\
\hline
\end{tabular}

\begin{tabular}{|c|c|c|c|c|}
\hline Financial Inputs & Reference & Optimistic & Conservative & Units \\
\hline \multirow{3}{*}{$\begin{array}{l}\text { Inflation } \\
\text { Real discount rate } \\
\text { Analysis period }\end{array}$} & 4.4 & & & $\%$ \\
\hline & $14 \%$ & $13.3 \%$ & $14.7 \%$ & $\%$ \\
\hline & 20 & & & years \\
\hline Target IRR & $14 \%$ & & & $\%$ \\
\hline \multirow{2}{*}{$\begin{array}{l}\text { PPA price } \\
\text { Federal tax rate }\end{array}$} & $\$ 0.1138$ & & & USD/kWh \\
\hline & $25 \%$ & & & $\%$ \\
\hline \multirow{4}{*}{$\begin{array}{l}\text { DSCR } \\
\text { Interest rate } \\
\text { Project debt term } \\
\text { Depreciation }\end{array}$} & 2.0 & & & \\
\hline & $8 \%$ & $7.60 \%$ & $8.40 \%$ & $\%$ \\
\hline & 18 & & & years \\
\hline & 15-year straight-line & & & \\
\hline
\end{tabular}


Table A-2.Sabu

\begin{tabular}{|c|c|c|c|c|}
\hline System Specs and Load & Reference & Optimistic & Conservative & Units \\
\hline Capacity & 350 & & & $\mathrm{~kW}$ \\
\hline Load served & 715,065 & & & $\mathrm{kWh} / \mathrm{yr}$ \\
\hline Capacity factor & $23.32 \%$ & $24.49 \%$ & $22.16 \%$ & CF \\
\hline Generation & 715,065 & & & ann kWh \\
\hline Degradation & $0.80 \%$ & $0.76 \%$ & $0.84 \%$ & $\% /$ year \\
\hline System Costs & Reference & Optimistic & Conservative & Units \\
\hline Capital Cost & $\$ 1,575,000$ & & & USD \\
\hline$\$ / W$ & $\$ 4.50$ & $\$ 4.28$ & $\$ 4.73$ & USD/W \\
\hline O\&M/yr & $\$ 10,150$ & $\$ 9,643$ & $\$ 10,658$ & USD/yr \\
\hline Financial Inputs & Reference & Optimistic & Conservative & Units \\
\hline Inflation & 4.4 & & & $\%$ \\
\hline Real discount rate & $14 \%$ & $13.30 \%$ & $14.70 \%$ & $\%$ \\
\hline Analysis period & 20 & & & years \\
\hline Target IRR & 14 & & & $\%$ \\
\hline PPA price & $\$ 0.20$ & & & USD/kWh \\
\hline Federal tax rate & $25 \%$ & & & $\%$ \\
\hline DSCR & 1.3 & 1.3 & 1.3 & \\
\hline Interest rate & $8 \%$ & $7.60 \%$ & $8.40 \%$ & $\%$ \\
\hline Project debt term & 18 & & & years \\
\hline Depreciation & 15-year straight-line & & & \\
\hline Replacement & Reference & Optimistic & Conservative & Units \\
\hline Inverter Cost & $\$ 0.1125$ & $\$ 0.10688$ & $\$ 0.11813$ & USD/W \\
\hline Inverter Life & 15 & & & years \\
\hline Inverter Depreciation & 15-year straight-line & & & \\
\hline
\end{tabular}


Table A-3. Sabu Hybrid PV-Battery Inputs

\begin{tabular}{|c|c|c|c|c|}
\hline System Specs and Load & Reference & Optimistic & Conservative & Units \\
\hline \multirow{5}{*}{$\begin{array}{l}\text { Capacity } \\
\text { Load served } \\
\text { Capacity factor } \\
\text { Generation } \\
\text { Degradation }\end{array}$} & 1,000 & & & kW \\
\hline & $2,043,045$ & & & $\mathrm{kWh} / \mathrm{yr}$ \\
\hline & $23.322 \%$ & $24.49 \%$ & $22.16 \%$ & $\mathrm{CF}$ \\
\hline & $2,043,045$ & & & ann kWh \\
\hline & $0.80 \%$ & $0.76 \%$ & $0.84 \%$ & $\% /$ year \\
\hline
\end{tabular}

\begin{tabular}{|c|c|c|c|c|}
\hline System Costs & Reference & Optimistic & Conservative & Units \\
\hline \multirow{4}{*}{$\begin{array}{l}\text { PV Capital Cost } \\
\$ / W \\
\text { Battery capital cost } \\
\text { O\&M/yr }\end{array}$} & $\$ 4,500,000$ & & & USD \\
\hline & $\$ 4.50$ & $\$ 4.28$ & $\$ 4.73$ & USD/W \\
\hline & $\$ 270,000$ & $\$ 256,500$ & $\$ 283,500$ & USD \\
\hline & $\$ 32,200$ & $\$ 30,590$ & $\$ 33,810$ & USD/yr \\
\hline
\end{tabular}

\begin{tabular}{|c|c|c|c|c|}
\hline Financial Inputs & Reference & Optimistic & Conservative & Units \\
\hline \multirow{2}{*}{$\begin{array}{l}\text { Inflation } \\
\text { Real discount rate }\end{array}$} & 4.4 & & & $\%$ \\
\hline & $14 \%$ & $13.30 \%$ & $14.70 \%$ & $\%$ \\
\hline \multirow{2}{*}{$\begin{array}{l}\text { Analysis period } \\
\text { Target IRR }\end{array}$} & 20 & & & years \\
\hline & 14 & & & $\%$ \\
\hline \multirow{2}{*}{$\begin{array}{l}\text { PPA price } \\
\text { Federal tax rate }\end{array}$} & $\$ 0.25$ & & & USD/kWh \\
\hline & $25 \%$ & & & $\%$ \\
\hline \multirow{4}{*}{$\begin{array}{l}\text { DSCR } \\
\text { Interest rate } \\
\text { Project debt term } \\
\text { Depreciation }\end{array}$} & 1.3 & 1.3 & 1.3 & \\
\hline & $8 \%$ & $7.60 \%$ & $8.40 \%$ & $\%$ \\
\hline & 18 & & & years \\
\hline & 15-year straight-line & & & \\
\hline Replacement & Reference & Optimistic & Conservative & Units \\
\hline \multirow{3}{*}{$\begin{array}{l}\text { Inverter Cost } \\
\text { Inverter Life } \\
\text { Inverter Depreciation }\end{array}$} & $\$ 0.1125$ & $\$ 0.10688$ & $\$ 0.11813$ & USD/W \\
\hline & 15 & & & years \\
\hline & 15-year straight-line & & & \\
\hline \multirow{3}{*}{$\begin{array}{l}\text { Inverter Cost } \\
\text { Inverter Life } \\
\text { Inverter Depreciation }\end{array}$} & $\$ 0.28273$ & $\$ 0.26859$ & $\$ 0.29687$ & USD/W \\
\hline & 16 & & & years \\
\hline & 15-year straight-line & & & \\
\hline
\end{tabular}




\section{Appendix B: Cost for Biogas Plant}

\section{Investment Costs}

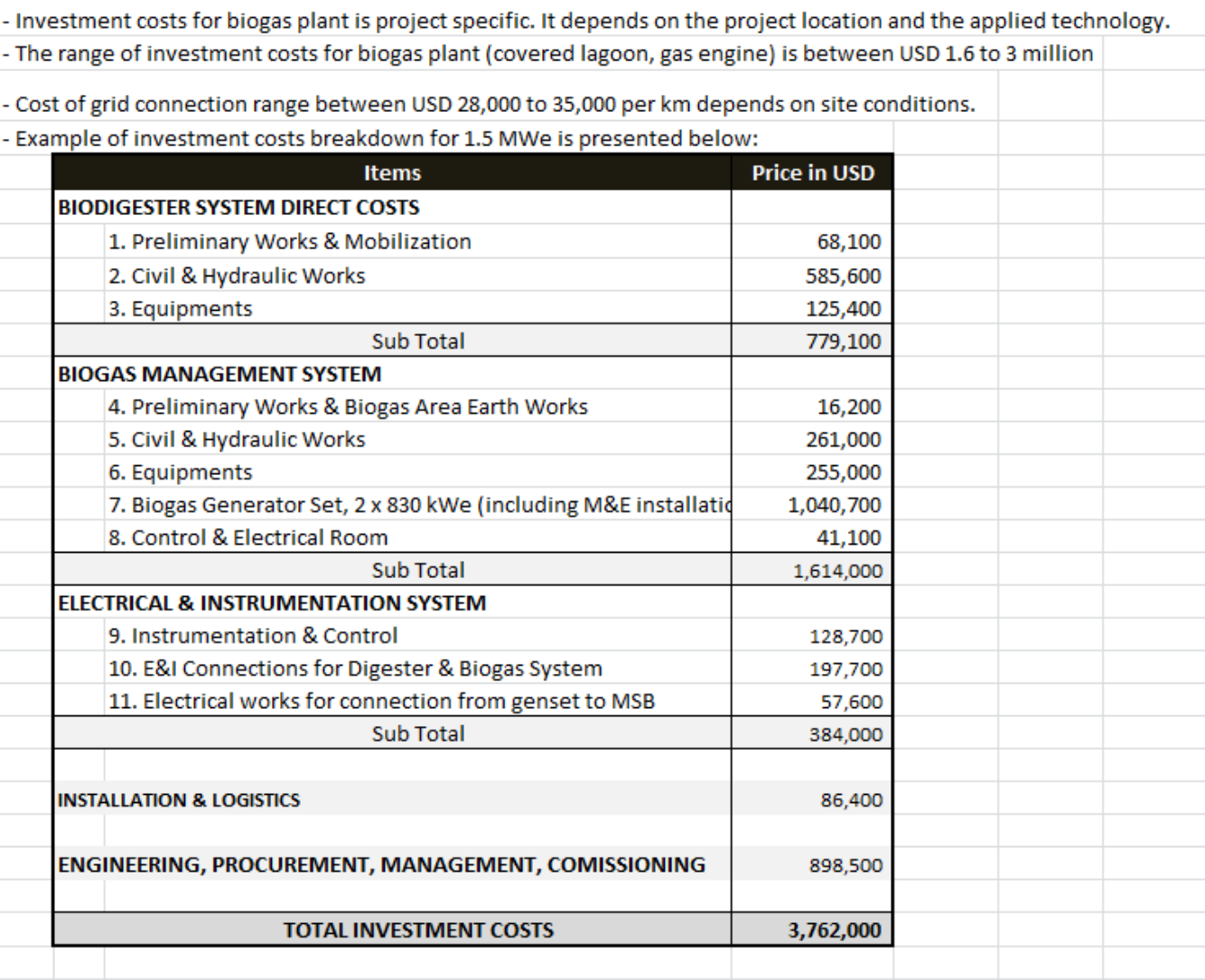

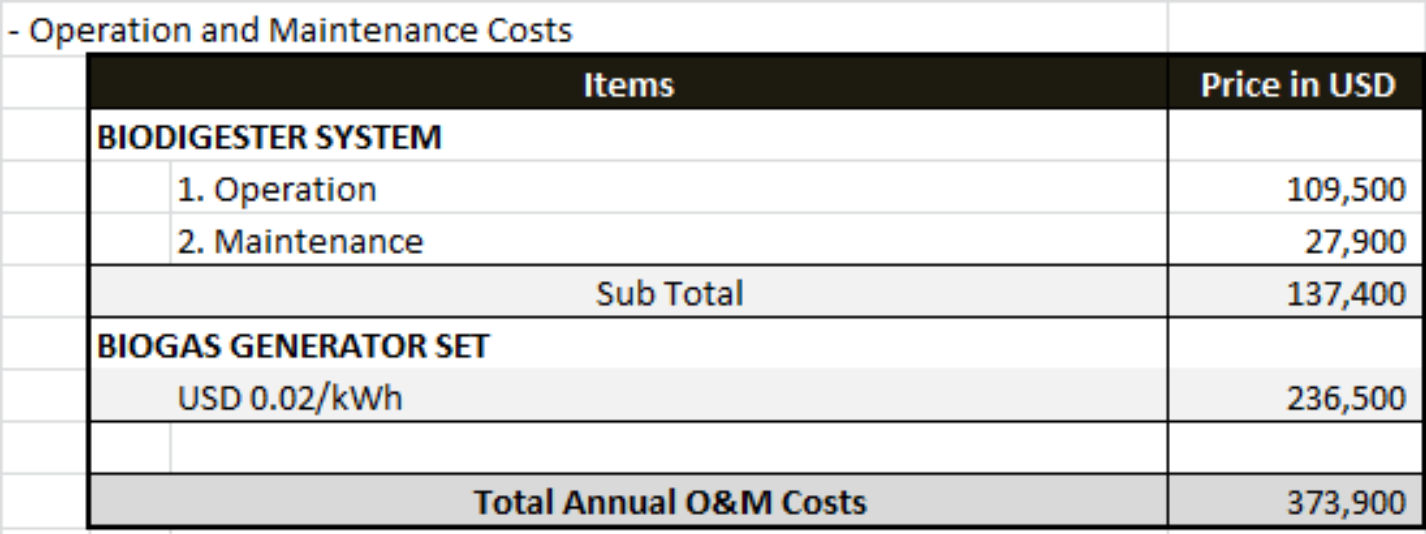

Source: CIRCLE project, Winrock International. 
Appendix C: Detailed Sumba Wind Characteristics at Hambapraing

Table C-1. Measurement Results (2012) for Hambapraing, Sumba Island

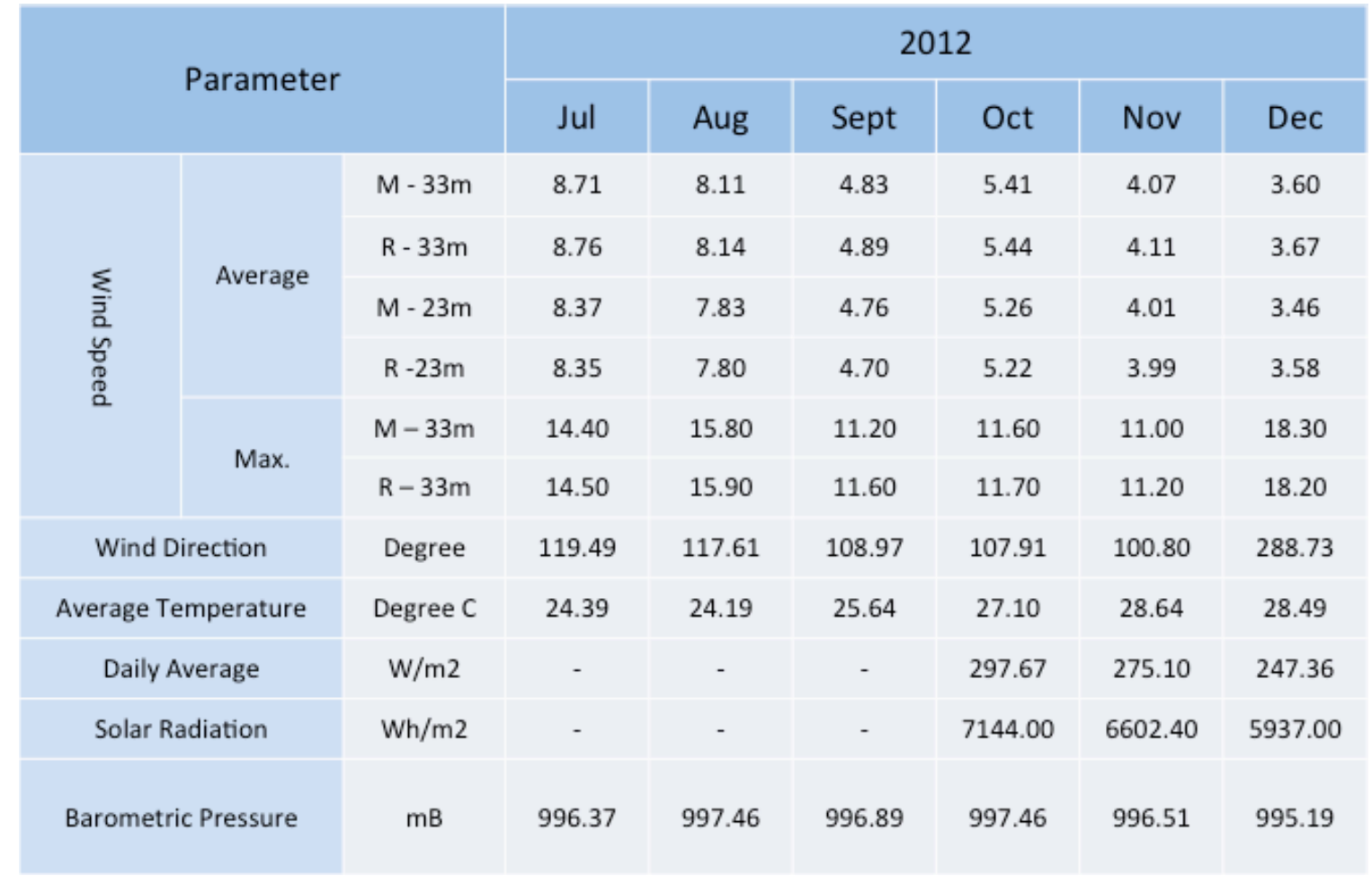

Table C-2. Measurement Results (2013) for Hambapraing, Sumba Island

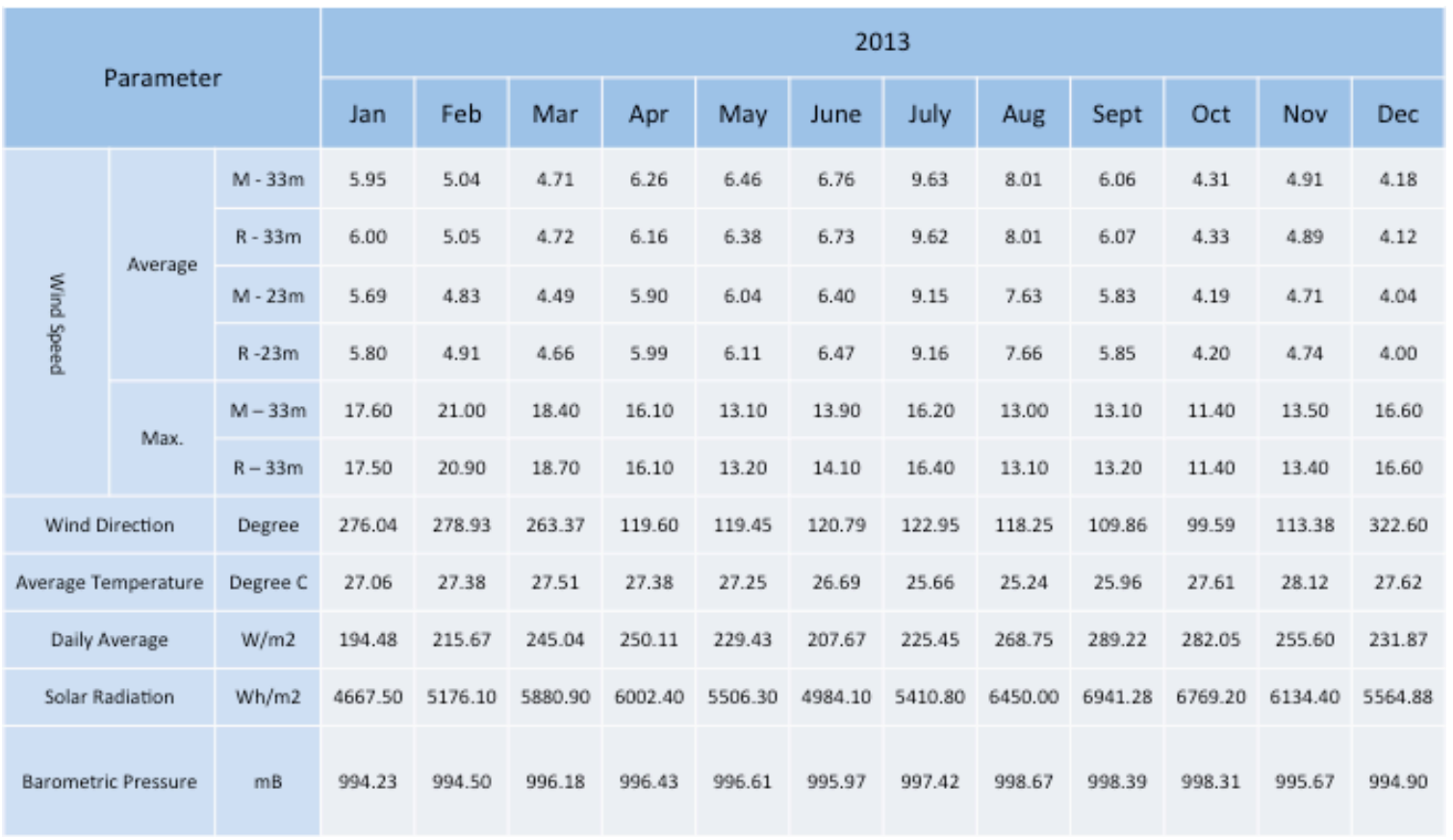


Table C-3. Measurement Results (2014) for Hambapraing, Sumba Island

\begin{tabular}{|c|c|c|c|c|c|c|c|c|c|c|c|c|}
\hline \multirow{2}{*}{\multicolumn{3}{|c|}{ Parameter }} & \multicolumn{10}{|c|}{2014} \\
\hline & & & Jan & Feb & Mar & Apr & May & June & Jul & Aug & Sep & Oct \\
\hline \multirow{6}{*}{ 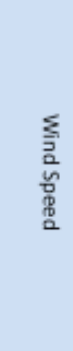 } & \multirow{4}{*}{ Average } & $M-33 m$ & 6.50 & 6.28 & 4.54 & 4.40 & 8.13 & 9.72 & 8.09 & 9.45 & 6.23 & 4.90 \\
\hline & & $R-33 m$ & 6.56 & 6.37 & 4.57 & 4.34 & 8.16 & 9.77 & 8.04 & 9.52 & 6.29 & 4.95 \\
\hline & & $M-23 m$ & 6.21 & 5.91 & 4.29 & 4.19 & 7.77 & 9.25 & 7.73 & 9.04 & 5.98 & 4.71 \\
\hline & & $R-23 m$ & 6.40 & 6.19 & 4.41 & 4.17 & 7.66 & 9.17 & 7.65 & 8.98 & 6.03 & 4.78 \\
\hline & \multirow{2}{*}{ Max. } & $M-33 m$ & 19.40 & 17.40 & 16.10 & 12.30 & 14.10 & 14.70 & 13.30 & 15.10 & 13.30 & 13.00 \\
\hline & & $R-33 m$ & 19.00 & 17.20 & 15.80 & 12.40 & 14.10 & 14.90 & 13.40 & 15.30 & 13.40 & 13.00 \\
\hline \multicolumn{2}{|c|}{ Wind Direction } & Degree & 277.13 & 276.23 & 156.16 & 119.52 & 120.67 & 119.69 & 118.36 & 118.52 & 114.65 & 110.84 \\
\hline \multicolumn{2}{|c|}{ Average Temperature } & Degree C & 27.30 & 26.44 & 27.41 & 27.46 & 27.43 & 26.26 & 25.17 & 25.04 & 25.60 & 27.30 \\
\hline \multicolumn{2}{|c|}{ Daily Average } & $\mathrm{W} / \mathrm{m} 2$ & 224.86 & 210.42 & 265.21 & 237.14 & 240.90 & 215.34 & 228.02 & 262.12 & 289.78 & 294.57 \\
\hline \multicolumn{2}{|c|}{ Solar Radiation } & $\mathrm{Wh} / \mathrm{m} 2$ & 5396.64 & 5050.08 & 6365.04 & 5691.36 & 5781.60 & 5168.16 & 5472.48 & 6290.88 & 6954.72 & 7069.68 \\
\hline \multicolumn{2}{|c|}{ Barometric Pressure } & $\mathrm{mB}$ & 994.84 & 994.90 & 996.91 & 996.91 & 997.79 & 997.59 & 998.89 & 999.61 & 999.64 & 998.78 \\
\hline
\end{tabular}

Table C-4. Wind Rose and Wind Speed Distribution (July 1, 2012 - November 1, 2014) for Hambapraing, Sumba Island

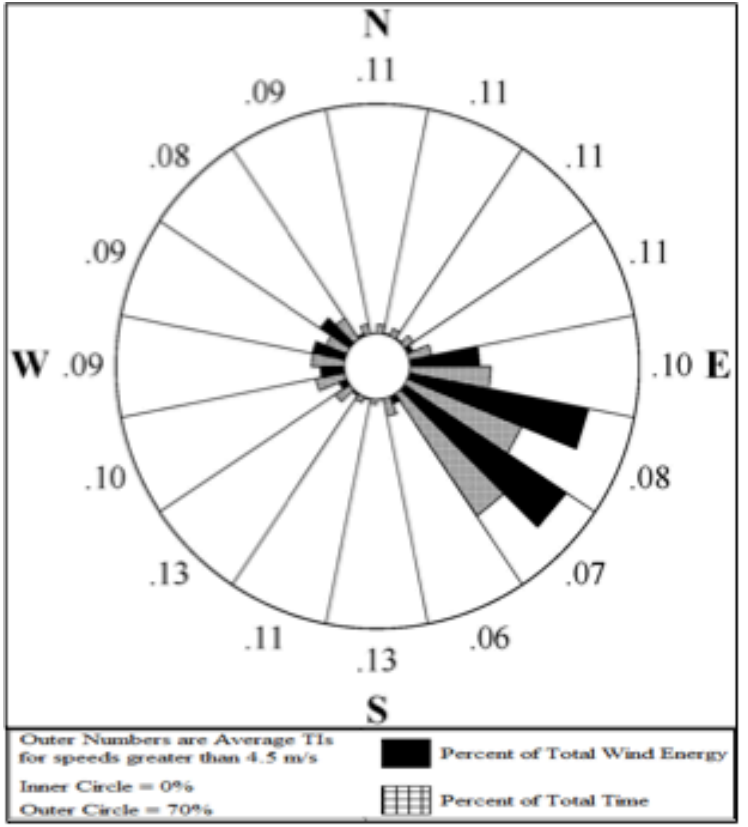

\begin{tabular}{|c|c|}
\hline Wind Speed $(\mathrm{m} / \mathrm{s})$ & Number of events at $33 \mathrm{~m}$ \\
\hline $0-1$ & 4390 \\
\hline $1-2$ & 6547 \\
\hline $2-3$ & 8699 \\
\hline $3-4$ & 10810 \\
\hline $4-5$ & 11440 \\
\hline $5-6$ & 11124 \\
\hline $6-7$ & 11679 \\
\hline $7-8$ & 11510 \\
\hline $8-9$ & 11055 \\
\hline $9-10$ & 9356 \\
\hline $10-11$ & 6646 \\
\hline $11-12$ & 3540 \\
\hline $12-13$ & 1616 \\
\hline $13-14$ & 726 \\
\hline $14-15$ & 364 \\
\hline $15-16$ & 183 \\
\hline $16-17$ & 33 \\
\hline $17-18$ & 3 \\
\hline $18-19$ & 3 \\
\hline $19-20$ & 2 \\
\hline
\end{tabular}




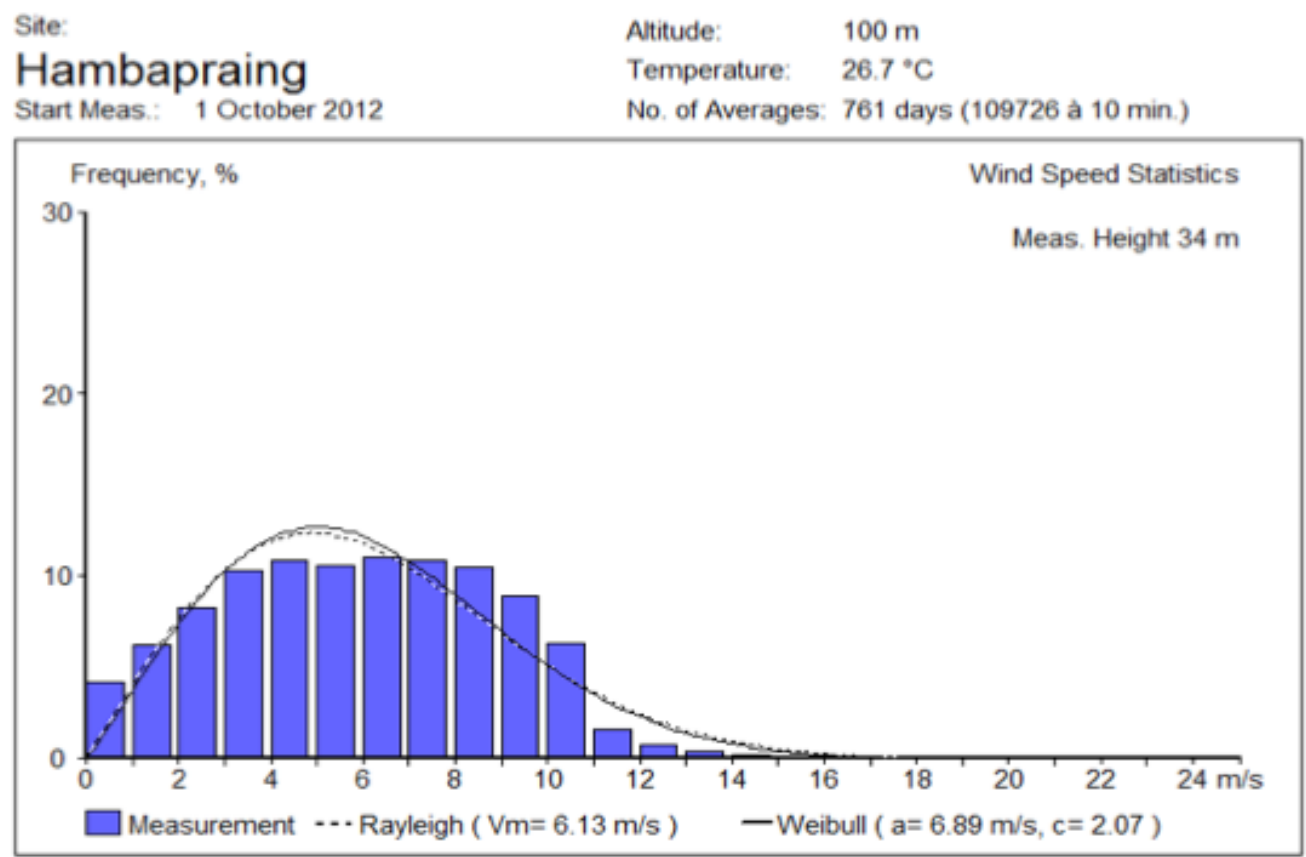

Figure C-1. Wind speed distribution (October 1, 2012 - November 12014 ) for Hambapraing, Sumba Island. 


\section{Appendix D: Pro Forma}

\subsection{WLLamandau Biogas Single Owner Cash Flow}

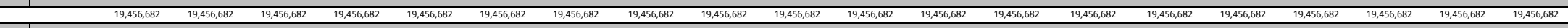
Reven

Net Production (AC-kWh)

Price (c/klkh)
Total PPA Revenue

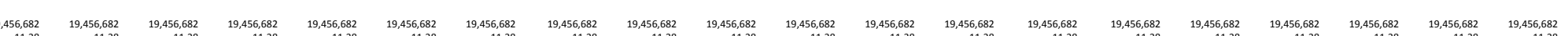

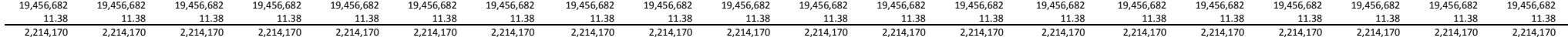
other $(\$ / M)$

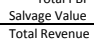

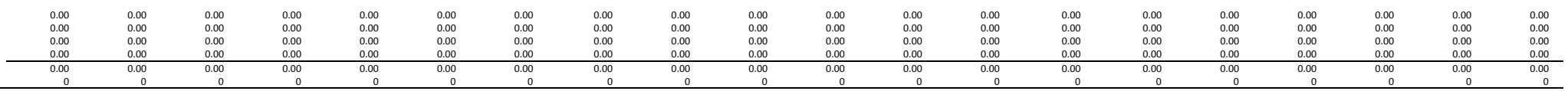

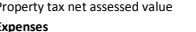
Expenses Fixed
Capacity
Capacity (DC KW)

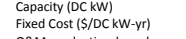
variable production-based
Generation (AC-MWh)

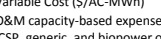
fuel (CSP, generic, and bitiopower
fuel (CSP and generic only) Property Tax
Insurance

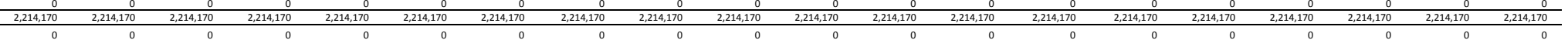
Total Expenses

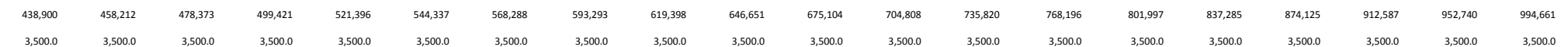
Cash Flow: Project
Cash Flow from Operating Activities

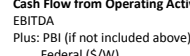
State $(S / N)$ Utility $(S / N)$
Other $(S M)$

Iotal
Plus: Interest Earned
Lessi lnterst Expense

\begin{tabular}{l} 
Plus: Interest Earned \\
Lessinterest txpense \\
\hline Total
\end{tabular}

Cash Flows from Investing Activities

Capital Costs
Total installed cos
Debt closing

Debt closing
Other financing
Construction finan

Construction financing
Total purchase of property

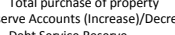

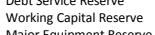

Major Equipment Reserve
Major Gquipment Reserve 2
Major Equipment Reserve 3

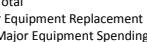

Major Equipment Spending 2
Major Equipment Spending

\begin{tabular}{l} 
Total \\
\hline Total (depreciable basis) \\
\hline Cash Flows from Financing Activities
\end{tabular}

Incentives an
IBI
CBI

Size of debt
Total

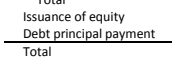

\begin{tabular}{|c|c|c|c|c|}
\hline $3,500.0$ & $3,3,500.0$ & \multicolumn{2}{|c|}{0.0} & $3,500.0$ \\
\hline
\end{tabular}

Pre-Tax Cashflow

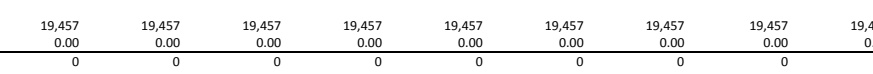

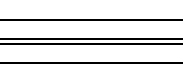

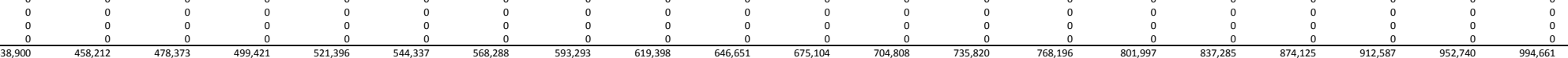

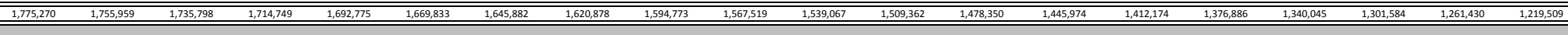

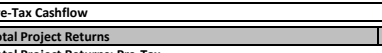

Equity Investment

$\frac{\text { Operting cash Distributions/(Contributions) }}{\text { Total }}$ Cumulative pre-tax IRR (\%)
Total
Croject Returns: After-Tex

Equity Inestment
operating cash istributions/(Contributions)
Total

$\begin{array}{llll}1,775,270 & 1,755,959 & 1,735,798 & 1,71470 \\ & & & \end{array}$
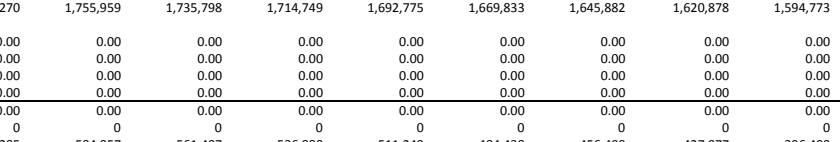

$1,567,50$
0.00
0.00
0.00
0.00
0.00
0.00
0.00
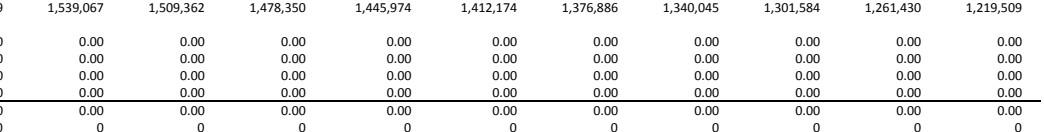

\section{$-8,778,000$
0}

$\begin{array}{r}0 \\ -175,560 \\ \hline-8,955,560\end{array}$
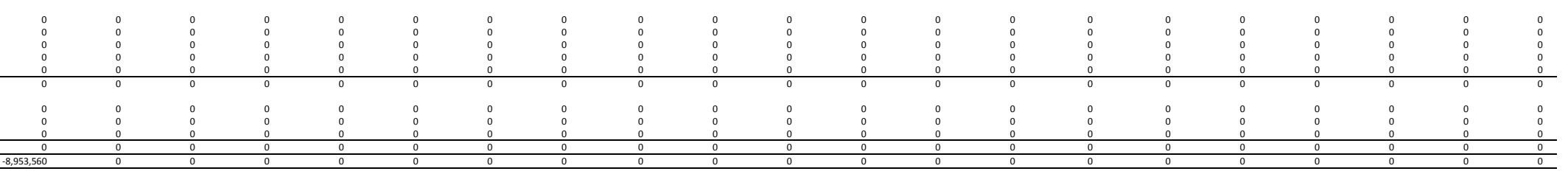

$-8,953,56$

$\begin{array}{r}0 \\ 0 \\ 7,591,066 \\ \hline 1591,066\end{array}$

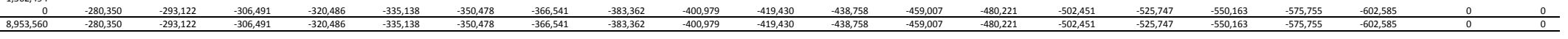

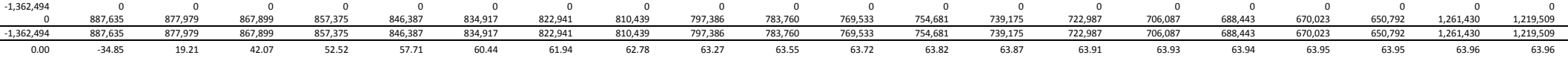

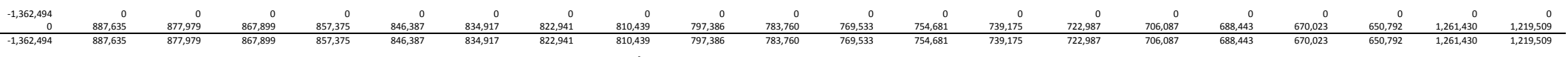
54

This report is available at no cost from the National Renewable Energy Laboratory (NREL) at www.nrel.gov/publications. 


\begin{tabular}{|c|c|c|c|c|c|c|c|c|c|c|c|c|c|c|c|c|c|c|c|c|c|}
\hline \multicolumn{22}{|l|}{$\begin{array}{c}\text { Investment Tax Credit } \\
\text { sfate } \\
\text { Federal } \\
\text { Total }\end{array}$} \\
\hline & & & & & & & & & & & & & & & & & & & & & \\
\hline $\begin{array}{c}\text { State } \\
\text { Federal }\end{array}$ & $\begin{array}{l}0 \\
0 \\
0\end{array}$ & $\begin{array}{l}0 \\
0 \\
\end{array}$ & $\begin{array}{l}0 \\
0 \\
\end{array}$ & $\begin{array}{l}0 \\
0 \\
0\end{array}$ & $\begin{array}{l}0 \\
0 \\
0\end{array}$ & $\begin{array}{l}0 \\
0 \\
0\end{array}$ & $\begin{array}{l}0 \\
0 \\
\end{array}$ & $\begin{array}{l}0 \\
0\end{array}$ & $\begin{array}{l}0 \\
0 \\
\end{array}$ & $\begin{array}{l}0 \\
0\end{array}$ & $\begin{array}{l}0 \\
0 \\
0\end{array}$ & $\begin{array}{l}0 \\
0 \\
0\end{array}$ & $\begin{array}{l}0 \\
0\end{array}$ & $\begin{array}{l}0 \\
0 \\
0\end{array}$ & $\begin{array}{c}0 \\
0 \\
0\end{array}$ & $\begin{array}{c}0 \\
0 \\
0\end{array}$ & $\begin{array}{l}0 \\
0 \\
0\end{array}$ & $\begin{array}{l}0 \\
0 \\
0\end{array}$ & $\begin{array}{l}0 \\
0\end{array}$ & $\begin{array}{c}0 \\
0\end{array}$ & - \\
\hline $\begin{array}{l}\text { Total } \\
\text { Tax Benefit/(Lability) }\end{array}$ & $0^{0}$ & & & & & & 0 & 0 & 0 & 0 & 0 & 0 & 0 & 0 & 0 & 0 & 0 & 0 & 0 & 0 & 0 \\
\hline $\begin{array}{c}\text { State } \\
\text { Federal } \\
\text { Total } \\
\end{array}$ & $\begin{array}{l}0 \\
0 \\
0 \\
\end{array}$ & $\begin{array}{l}-224,9012 \\
-224,912 \\
-{ }_{2}\end{array}$ & $\begin{array}{r}0 \\
-158,405 \\
-158,405 \\
\end{array}$ & $\begin{array}{l}-159,27 \\
-159,27 \\
-159,27\end{array}$ & $\begin{array}{l}-160,005 \\
-100,0905 \\
-100\end{array}$ & $\begin{array}{l}-161,011 \\
-1-11,1011 \\
-1\end{array}$ & 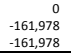 & $\begin{array}{r}-163,000 \\
-133,000 \\
-1\end{array}$ & $\begin{array}{l}-1640,00 \\
-1-14,800 \\
-1\end{array}$ & $\begin{array}{r}-165,21 \\
-15,21 \\
-155,211\end{array}$ & $\begin{array}{l}-166,427 \\
-106,427 \\
-127\end{array}$ & $\begin{array}{l}-167,702 \\
-167,702 \\
-1002\end{array}$ & $\begin{array}{l}0 \\
-169,253 \\
-1-9,253 \\
\end{array}$ & $\begin{array}{r}-170,49 \\
-1-10,499 \\
-100\end{array}$ & $\begin{array}{r}0 \\
-172,190 \\
-172,190 \\
-\end{array}$ & $\begin{array}{r}0 \\
-173,588 \\
-173,588\end{array}$ & $\begin{array}{r}0 \\
-242.57 \\
-225257\end{array}$ & $\begin{array}{r}0 \\
-311,445 \\
-311,45 \\
-\end{array}$ & $\begin{array}{r}0 \\
-313,344 \\
-313,34\end{array}$ & 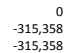 & $\begin{array}{r}0 \\
-304,877 \\
-3.04877\end{array}$ \\
\hline $\begin{array}{ll}\text { Total } \\
\end{array}$ & $-1,362,494$ & & & & & & & & & & & & & & & & & & & & \\
\hline \multicolumn{22}{|l|}{$\begin{array}{l}\text { NPV and IRR } \\
\end{array}$} \\
\hline Cumulative after-tax IR (\%) & 0.00 & -51.36 & 0.95 & $\begin{array}{l}24.56 \\
2456\end{array}$ & $\begin{array}{l}35.97 \\
3.57\end{array}$ & $\begin{array}{l}41.95 \\
441.5\end{array}$ & 45.27 & 47.20 & 48.35 & 49.06 & 49.50 & 49.77 & 49.95 & 50.06 & 50.13 & 50.18 & 50.20 & 50.21 & 50.22 & 50.24 & 50.25 \\
\hline $\begin{array}{l}\text { Maximum } \\
\text { Year target RR reached }\end{array}$ & $\begin{array}{l}0.00 \\
\end{array}$ & $\begin{array}{c}0.00 \\
0\end{array}$ & $\begin{array}{c}0.95 \\
0\end{array}$ & $\begin{array}{c}24.56 \\
0\end{array}$ & 35.97 & $\begin{array}{c}4.95 \\
0\end{array}$ & 45.27 & $\begin{array}{l}47.20 \\
0\end{array}$ & $\begin{array}{c}\begin{array}{c}48.35 \\
0\end{array} \\
0\end{array}$ & 等.06 & $\begin{array}{l}49.50 \\
0\end{array}$ & $\begin{array}{l}49.77 \\
0\end{array}$ & $\begin{array}{c}49.95 \\
0\end{array}$ & $\begin{array}{l}5.06 \\
0\end{array}$ & $\begin{array}{c}5.13 \\
0\end{array}$ & $\begin{array}{l}50.18 \\
0\end{array}$ & $\begin{array}{c}50.20 \\
0\end{array}$ & $\begin{array}{c}50.21 \\
0\end{array}$ & $\begin{array}{l}50.22 \\
0\end{array}$ & $\begin{array}{c}50.24 \\
0\end{array}$ & $\begin{array}{c}5.25 \\
0\end{array}$ \\
\hline NPV of after-tax returns & \begin{tabular}{|l|l|}
$2,021,011$ \\
\end{tabular} & & & & & & & & & & & & & & & & & & & & \\
\hline
\end{tabular}

\section{$350 k$ S Sabu PV Single Owner Cash Flow}

Operating Year

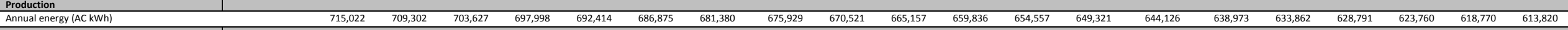
Partial Income Statement: $P$ igec
Revenues

Revenues
PPA

Net Production (AC-kWh Price $(\mathcal{c} / \mathrm{kWh})$
Total PAA Revenue

Price (c/kWh)
Total PPA Revenue
Production Based lncentive (included if available for debt service)
Federal (S/W)

State $(\$ / W)$
Utility $(\$ / W)$
Other $(\$ / W)$

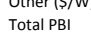

\begin{tabular}{l} 
Salvage Value \\
\hline Total Revenue \\
\hline Prapertax
\end{tabular}

Property tax net assessed value
Expenses

Expenses
Operation and maintenance (O\&M)

Fixed

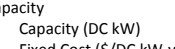

O\&M production-based expense

Variable

Generation (AC-MWh)
Variable Cost (\$/AC-MWh)

O\&M capacity-based expense

Fuel (CSP, generic, and biopower only)

Fuel (CSP and generic only)
Biomass feedstock (Biopower on

Coal feedstock (Biopower only)

Property Tax

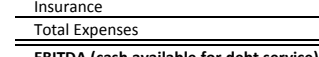

\section{\begin{tabular}{l} 
EBITDA (cash available for debt service) \\
\hline Cash Flow: Project \\
CSsh Flow from Oprating Activities
\end{tabular}}

BITDA

Plus: PBI (if not included above)
Federal $(S /(W)$

Federal $(\$ / \mathrm{W})$
State $(\$ / \mathrm{W})$

Utility $(S / W)$

Other $(s / \mathrm{W})$

Plus: Interest Earned

Less: Interest Expense
Lense

Total

Capital Costs
Total installed cost

Dobt losing
Other financing

Other financing
Construction financing

Total purchase of property
serve Accounts (Increase//Decc

Debt Service Reserve

Morking Cquipital Reserve

Major Equipment Reserve 2

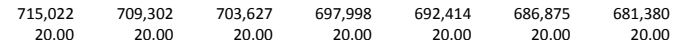

\begin{tabular}{rr}
$675,929 \quad 670,521$ \\
\hline
\end{tabular}

\begin{tabular}{rrrrr}
2000 & 665,157 & 659,836 & 654,557 & 649,321 \\
\hline & 2000 & 20.00 & 2000 & 2300 \\
\hline
\end{tabular}

644,126
20.00

\begin{tabular}{llllll}
638,973 & 633,862 & 628,791 & 623,760 & 618,770 & 613,820 \\
\hline
\end{tabular}

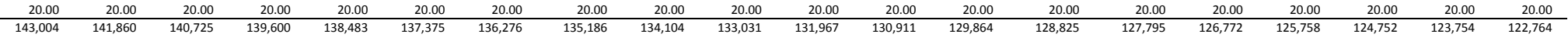

\begin{tabular}{|c|c|c|c|c|c|c|c|c|c|c|c|c|c|c|c|c|c|c|}
\hline 10 & 0.00 & 0.00 & 0.00 & 0.00 & 0.00 & 0.00 & 0.00 & 0.00 & 0.00 & 0.00 & 0.00 & 0.00 & 0.00 & 0.00 & 0.00 & 0.00 & & 0.00 \\
\hline & 0.00 & 0.00 & & & 0.00 & 0.00 & 0.00 & 0.00 & 0.00 & 0.00 & 0.00 & 0.00 & 0.00 & 0.00 & 0.00 & 0.00 & 0.00 & 0.00 \\
\hline 0.00 & 0.00 & 0.00 & 0.00 & 0.00 & 0.00 & 0.00 & 0.00 & 0.00 & 0.00 & 0.00 & 0.00 & 0.00 & 0.00 & 0.00 & 0.00 & 0.00 & 0.00 & 0.00 \\
\hline
\end{tabular}

This report is available at no cost from the National Renewable Energy Laboratory (NREL) at www.nrel.gov/publications. 
Major Equipment Reserve 3

Total
Major Equi

uipment Replacement

Majoj Equipment Spending 1
Major Equipment Spending 2

Major Equipment Spending 3

Total (depreciable basis)

Cash Flows from Financing Activities

Incentives and size of debt
IBI

IBI
CBI
Size of debt

Size of deb
Total
Issuance of

Iotal
Issuance of equity

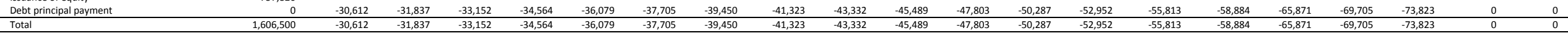

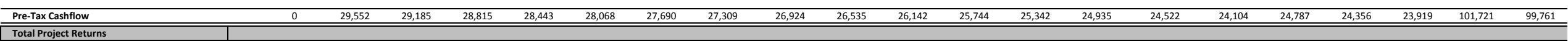

Total Project Returns

Equity Investment
Operating Cash

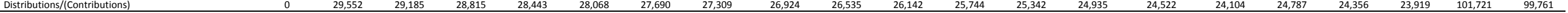

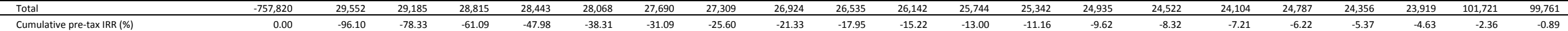

Cumulative pre-tax IRR (\%)

Equity Investment
Operating Cash

Distributions/(Contributions)

Total
Investment Tax Credit

State

Federal
Total

Total
Production Tax Credit

State
Federal

Total
Tax Benefit/(Liability)

State
Federal

NPY and IRR

Cumulative after-tax IRR (\%)

Maximum
Year target IRR reached

NPV of after-tax returns

$-757,820$

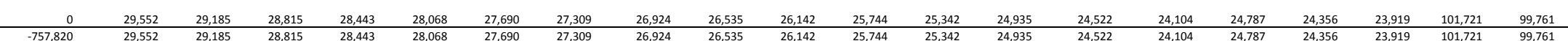

\section{MW Sabu PV-Battery Single Owner Cash Flow}

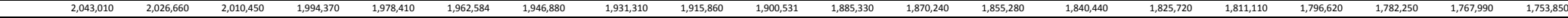

Net Production (AC-kWh)

ive (included if avaliable for debt service)

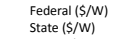

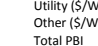

$\frac{\text { Salvage Value }}{\text { Total Revenue }}$

Expenses
Operation and maintenance (OSM)

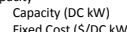

Geriable
Generation (AC-MWh)
Varialle Cost $(S / A C-M W h)$

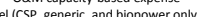

Fuel (ISP and generic only)

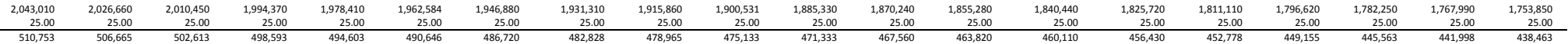

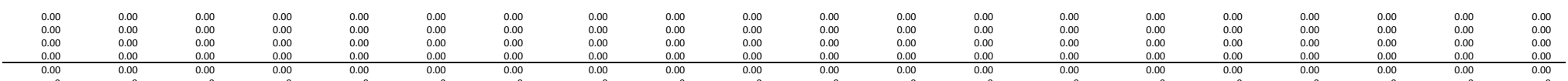

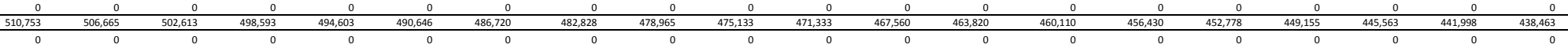

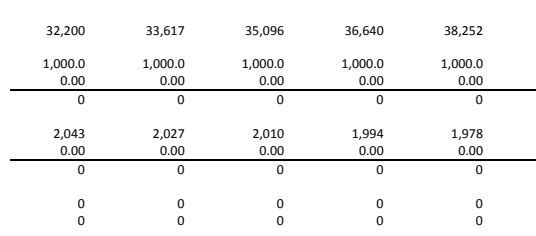

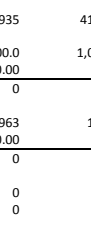

$\quad 43,527$

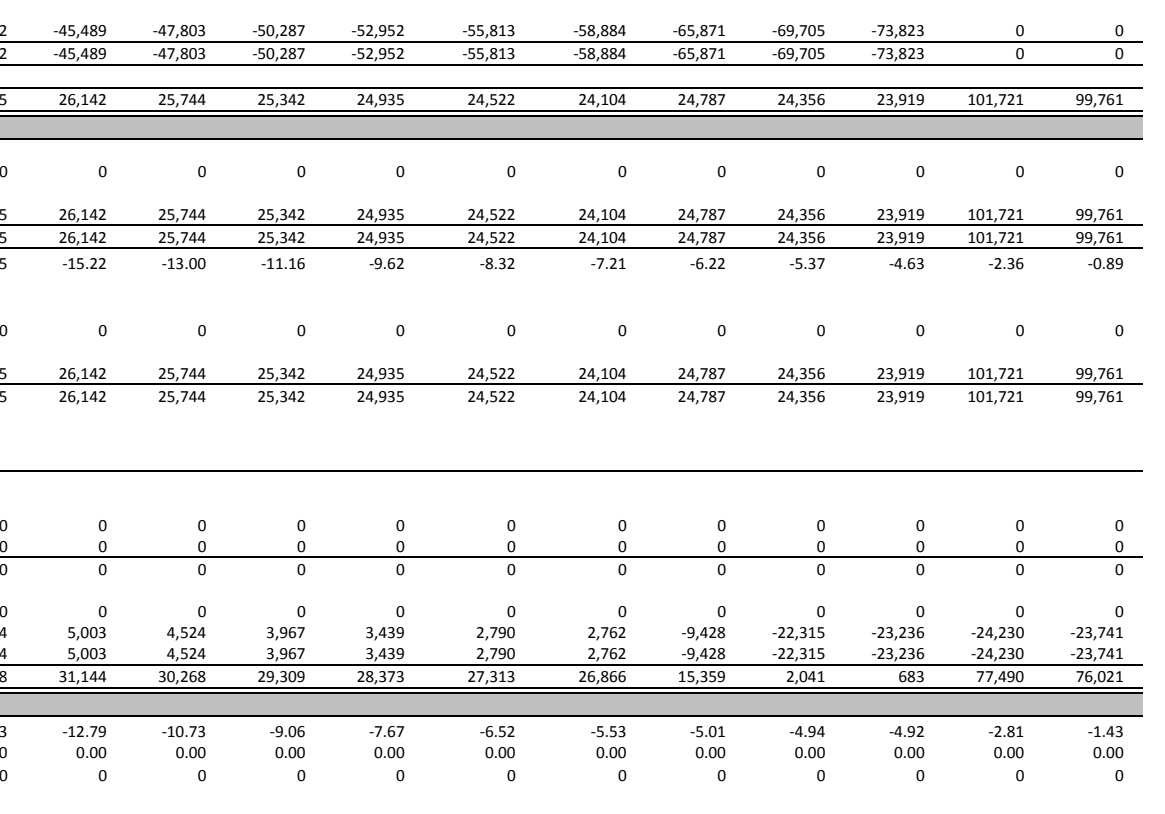

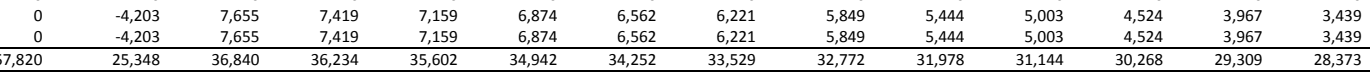




\begin{tabular}{|c|c|c|c|c|c|c|c|c|c|c|c|c|c|c|c|c|c|c|c|c|c|}
\hline $\begin{array}{l}\text { Coalf feedstock (Biopower only) } \\
\begin{array}{l}\text { Property } \\
\text { insurax }\end{array}\end{array}$ & & $\begin{array}{l}0 \\
0 \\
0 \\
\end{array}$ & $\begin{array}{l}0 \\
0 \\
0 \\
\end{array}$ & $\begin{array}{l}0 \\
0 \\
0 \\
\end{array}$ & $\begin{array}{l}0 \\
0 \\
0 \\
\end{array}$ & $\begin{array}{l}0 \\
0 \\
0\end{array}$ & $\begin{array}{l}0 \\
0 \\
0 \\
\end{array}$ & $\begin{array}{l}0 \\
0 \\
0 \\
\end{array}$ & $\begin{array}{l}0 \\
0 \\
0\end{array}$ & $\begin{array}{l}0 \\
0 \\
0\end{array}$ & $\begin{array}{l}0 \\
0 \\
0\end{array}$ & $\begin{array}{l}0 \\
0 \\
0\end{array}$ & $\begin{array}{l}0 \\
0 \\
0\end{array}$ & $\begin{array}{l}0 \\
0 \\
0\end{array}$ & $\begin{array}{l}0 \\
0 \\
0\end{array}$ & $\begin{array}{l}0 \\
0 \\
0\end{array}$ & $\begin{array}{l}0 \\
0 \\
0\end{array}$ & $\begin{array}{l}0 \\
0 \\
0\end{array}$ & $\begin{array}{l}0 \\
0 \\
0\end{array}$ & $\begin{array}{l}0 \\
0 \\
0\end{array}$ & 72074 \\
\hline $\begin{array}{l}\frac{1 \text { nsurance }}{\text { Total Kxenses }} \\
\end{array}$ & & 32,200 & 33,617 & 35,096 & 36,640 & 38,252 & 39,935 & 41,693 & $\begin{aligned} 23,527 \\
\end{aligned}$ & $\begin{aligned} 45,442 \\
\end{aligned}$ & $\begin{aligned} 47,442 \\
\end{aligned}$ & 49,529 & 51,708 & 53,984 & 56,359 & 58,839 & 61,428 & 64,130 & 66,952 & 69,898 & 72,974 \\
\hline EBITDA (cash available for debt service) & & $\begin{array}{lll}47,5533 \\
\end{array}$ & $\begin{array}{lll}473,048 \\
\end{array}$ & $\begin{array}{llll}467,517 \\
\end{array}$ & 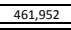 & 456,350 & $\begin{array}{lll}450,711 \\
\end{array}$ & $\begin{array}{llll}445,027 \\
\end{array}$ & $\begin{array}{ll}439,300 \\
\end{array}$ & $\begin{array}{l}433,523 \\
\end{array}$ & $\begin{array}{l}427,691 \\
\end{array}$ & $\begin{array}{lll}421,803 \\
\end{array}$ & 4415,852 & $\begin{array}{lll}409,836 \\
\end{array}$ & $\begin{array}{lll}403,751 \\
\end{array}$ & $\begin{array}{lll}397,591 \\
\end{array}$ & 391,350 & $\begin{array}{lll}385,025 \\
\end{array}$ & $\begin{array}{l}378,610 \\
\end{array}$ & 372,099 & $\begin{array}{lll}365,489 \\
\end{array}$ \\
\hline \multicolumn{22}{|l|}{ 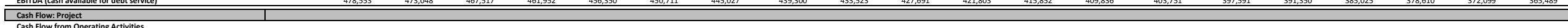 } \\
\hline 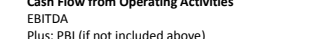 & & 478,553 & 473,048 & 467,517 & 461,952 & 456,350 & 450,711 & 445,027 & 439,300 & 433,523 & 427,691 & 421,803 & 415,852 & 409,836 & 403,751 & 397,591 & 391,350 & 385,025 & 378,610 & 372,099 & 365,489 \\
\hline 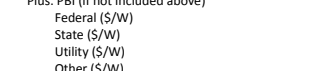 & & $\begin{array}{l}0.00 \\
0.00 \\
0.00 \\
0.00\end{array}$ & $\begin{array}{l}0.00 \\
0.00 \\
0.00 \\
0.00\end{array}$ & $\begin{array}{l}0.00 \\
0.00 \\
0.00 \\
0.00\end{array}$ & $\begin{array}{l}0.00 \\
0.00 \\
0.00 \\
0.00\end{array}$ & $\begin{array}{l}0.00 \\
0.00 \\
0.00 \\
0.00\end{array}$ & $\begin{array}{l}0.00 \\
0.00 \\
0.00 \\
0.00\end{array}$ & $\begin{array}{l}0.00 \\
0.00 \\
0.00 \\
0.00\end{array}$ & $\begin{array}{l}0.00 \\
0.00 \\
0.00 \\
0.00\end{array}$ & $\begin{array}{l}0.00 \\
0.00 \\
0.00 \\
0.00\end{array}$ & $\begin{array}{l}0.00 \\
0.00 \\
0.00 \\
0.00\end{array}$ & $\begin{array}{l}0.00 \\
0.00 \\
0.00 \\
0.00\end{array}$ & $\begin{array}{l}0.00 \\
0.00 \\
0.00 \\
0.00\end{array}$ & $\begin{array}{l}0.00 \\
0.00 \\
0.00 \\
0.00\end{array}$ & $\begin{array}{l}0.00 \\
0.00 \\
0.00 \\
0.00\end{array}$ & $\begin{array}{l}0.00 \\
0.00 \\
0.00 \\
0.00\end{array}$ & $\begin{array}{l}0.00 \\
0.00 \\
0.00 \\
0.00\end{array}$ & $\begin{array}{l}0.00 \\
0.00 \\
0.00 \\
0.00\end{array}$ & $\begin{array}{l}0.00 \\
0.00 \\
0.00 \\
0.00\end{array}$ & $\begin{array}{l}0.00 \\
0.00 \\
0.00 \\
0.00\end{array}$ & $\begin{array}{l}0.00 \\
0.00 \\
0.00 \\
0.00\end{array}$ \\
\hline 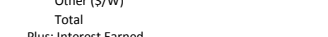 & & 0.00 & 0.00 & 0.00 & 0.00 & 0.00 & 0.00 & 0.00 & 0.00 & 0.00 & 0.00 & 0.00 & 0.00 & 0.00 & 0.00 & 0.00 & 0.00 & 0.00 & 0.00 & 0.00 & \\
\hline $\begin{array}{l}\text { Plus: Interest Earned } \\
\text { Less: Interest Expense } \\
\end{array}$ & $\begin{array}{c}0 \\
0 \\
\end{array}$ & $\begin{array}{r}0 \\
-229,097\end{array}$ & $\begin{array}{r}-220,893 \\
\end{array}$ & $\begin{aligned}-212,372 \\
-120\end{aligned}$ & $\begin{array}{r}-20,509 \\
\end{array}$ & $\begin{array}{l}-194,280 \\
-\end{array}$ & $\begin{array}{l}-184,557 \\
-120\end{array}$ & $\begin{array}{r}-174,12 \\
-172\end{array}$ & $\begin{array}{l}0 \\
-164,1122 \\
\end{array}$ & $\begin{array}{r}0 \\
-153,125 \\
\end{array}$ & $\begin{array}{r}0 \\
-141,615 \\
\end{array}$ & $\begin{array}{c}-129,542 \\
-12\end{array}$ & $\begin{aligned} 0 \\
-116,866 \\
0\end{aligned}$ & $\begin{array}{r}-103,42 \\
-\end{array}$ & $\begin{array}{r}0 \\
-89,523 \\
-1\end{array}$ & $\begin{aligned} 0 \\
-74,756 \\
0\end{aligned}$ & $\begin{array}{r}0 \\
-59,188 \\
\end{array}$ & $\begin{aligned} 0 \\
-41,914\end{aligned}$ & $\begin{array}{r}0 \\
-21,573 \\
-1\end{array}$ & $\begin{array}{l}0 \\
0 \\
0\end{array}$ & $\begin{array}{l}0 \\
0\end{array}$ \\
\hline & 255,145 & 258,443 & 262,070 & 266,053 & 270,416 & 275,188 & 280,398 & 286,076 & 2992,261 & 298,985 & 306,294 & & 322,835 & 332,162 & 34,3111 & 357,037 & & \\
\hline 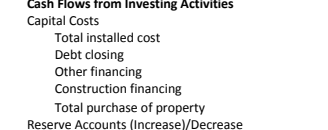 & $\begin{array}{r}-4,77,000 \\
0 \\
0 \\
-95,400 \\
-4,865,400\end{array}$ & & & & & & & & & & & & & & & & & & & & \\
\hline $\begin{array}{l}\text { Debt Service Reserve } \\
\text { Workrin Capital Reserve } \\
\text { Major Equipment Reserve } 1 \\
\text { Major Equipmente Reserve 2 } \\
\text { Major Equipment Reserve } 3\end{array}$ & $\begin{array}{l}0 \\
0 \\
0 \\
0 \\
0 \\
0 \\
\end{array}$ & $\begin{array}{r}0 \\
0 \\
-13,05 \\
-33,710 \\
0 \\
\end{array}$ & $\begin{array}{r}0 \\
0 \\
-13,705 \\
-33,710 \\
0 \\
\end{array}$ & $\begin{array}{r}0 \\
0 \\
-13,705 \\
-33,710 \\
0 \\
\end{array}$ & $\begin{array}{r}0 \\
0 \\
-13,705 \\
-33,710\end{array}$ & $\begin{array}{r}0 \\
0 \\
-13,705 \\
-33,710 \\
0 \\
\end{array}$ & $\begin{array}{r}0 \\
-13,705 \\
-33,10\end{array}$ & $\begin{array}{r}0 \\
0 \\
-13,705 \\
-33,710 \\
0 \\
\end{array}$ & $\begin{array}{r}0 \\
0 \\
-13,705 \\
-33,710 \\
0 \\
\end{array}$ & $\begin{array}{r}0 \\
0 \\
-13,705 \\
-33,710 \\
0 \\
\end{array}$ & $\begin{array}{r}0 \\
0 \\
-13,705 \\
-33,710 \\
0 \\
\end{array}$ & $\begin{array}{r}0 \\
0 \\
-13,705 \\
-33,710 \\
0 \\
\end{array}$ & $\begin{array}{r}0 \\
0 \\
-13,705 \\
-33,710 \\
0\end{array}$ & $\begin{array}{r}0 \\
0 \\
-13,705 \\
-33,710 \\
0 \\
\end{array}$ & $\begin{array}{r}0 \\
0 \\
0 \\
-13,705 \\
-33,710 \\
0\end{array}$ & $\begin{array}{r}0 \\
0 \\
191,85 \\
-33,710 \\
0\end{array}$ & $\begin{aligned} 0 \\
0 \\
0 \\
505,51 \\
0\end{aligned}$ & $\begin{array}{l}0 \\
0 \\
0 \\
0 \\
0\end{array}$ & $\begin{array}{l}0 \\
0 \\
0 \\
0 \\
0 \\
0\end{array}$ & $\begin{array}{l}0 \\
0 \\
0 \\
0 \\
0\end{array}$ & \\
\hline $\begin{array}{l}\text { Total } \\
\text { Major Geument Replacement }\end{array}$ & $0^{\circ}$ & $-47,415$ & $-47,415$ & $-47,415$ & $-47,415$ & $-47,415$ & $-47,415$ & $-47,415$ & $-47,415$ & $-47,415$ & $-47,415$ & $-47,415$ & $-47,415$ & $-47,415$ & $-47,415$ & 158,155 & 505,651 & 0 & 0 & 0 & 0 \\
\hline $\begin{array}{l}\text { Major Equipments Spending } 1 \\
\text { Maior Equipments Spending } 2 \\
\text { Major Equipment Spending } 3\end{array}$ & $\begin{array}{l}0 \\
0 \\
0 \\
0\end{array}$ & $\begin{array}{l}0 \\
0 \\
0 \\
\end{array}$ & $\begin{array}{l}0 \\
0 \\
0 \\
\end{array}$ & $\begin{array}{l}0 \\
0 \\
0 \\
\end{array}$ & $\begin{array}{l}0 \\
0 \\
0 \\
\end{array}$ & $\begin{array}{l}0 \\
0 \\
0 \\
\end{array}$ & $\begin{array}{l}0 \\
0 \\
0 \\
\end{array}$ & $\begin{array}{l}0 \\
0 \\
0 \\
\end{array}$ & $\begin{array}{l}0 \\
0 \\
0 \\
\end{array}$ & $\begin{array}{l}0 \\
0 \\
0 \\
\end{array}$ & $\begin{array}{l}0 \\
0 \\
0 \\
\end{array}$ & $\begin{array}{l}0 \\
0 \\
0 \\
\end{array}$ & $\begin{array}{l}0 \\
0 \\
0 \\
\end{array}$ & $\begin{array}{l}0 \\
0 \\
0 \\
\end{array}$ & $\begin{array}{l}0 \\
0 \\
0 \\
\end{array}$ & $\begin{aligned}-20,570 \\
0 \\
0 \\
\end{aligned}$ & $\begin{array}{r}0 \\
-539,361 \\
0 \\
\end{array}$ & $: 0$ & $\begin{array}{l}0 \\
0 \\
0 \\
0\end{array}$ & $\begin{array}{l}0 \\
0 \\
0\end{array}$ & 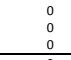 \\
\hline $\begin{array}{l}\text { Total } \\
\text { Total (depreciable basis) } \\
\end{array}$ & $\begin{array}{l}-4,865,400 \\
-1\end{array}$ & $\begin{aligned} 0 \\
-44,415 \\
\end{aligned}$ & $\begin{aligned} 0 \\
-47,415 \\
\end{aligned}$ & $\frac{0}{-47,415}$ & $\begin{aligned} 0 \\
-47,415 \\
\end{aligned}$ & $\frac{0}{-47,415}$ & $\frac{0}{-47,415}$ & $\frac{0}{-47,415}$ & 0 & $\begin{array}{l}0 \\
-47,415 \\
\end{array}$ & $\frac{0}{-47,415}$ & $\frac{0}{-47,415}$ & $\frac{0}{-47,415}$ & $\begin{array}{l}0 \\
-47,415 \\
\end{array}$ & $\frac{0}{-47,415}$ & 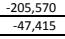 & $\begin{array}{l}-539,361 \\
-33,710 \\
-10\end{array}$ & $\frac{0}{0}$ & $\frac{0}{0}$ & $\frac{0}{0}$ & $\frac{0}{0}$ \\
\hline \multicolumn{22}{|l|}{ 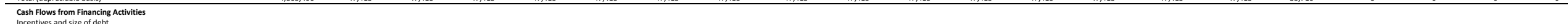 } \\
\hline $\begin{array}{l}\text { Issuance of equity } \\
\text { Debt principal payment } \\
\end{array}$ & $\begin{aligned} 2,01,053 \\
0 \\
\end{aligned}$ & -102,547 & $-106,517$ & - 110,783 & $-115,366$ & -120,286 & - $-125,570$ & - $-131,244$ & $-137,338$ & $-143,881$ & $-150,906$ & - 158,449 & -166,547 & $-175,244$ & -184,582 & -194,610 & $-215,920$ & $-254,259$ & $-269,666$ & 0 & \\
\hline & & $-102,547$ & $0.60,517$ & $-110,783$ & 115,366 & 120,286 & 225,570 & $-133,244$ & 137,338 & 144,881 & $-150,906$ & $-158,499$ & $-166,547$ & $-175,244$ & $\begin{array}{l}-184,5822 \\
-1\end{array}$ & $-1994,610$ & $-215,920$ & $-254,259$ & $-269,666$ & 0 & - \\
\hline $\begin{array}{l}\text { Pre-Tax Cashflow } \\
\end{array}$ & 0 & 99,493 & 98,223 & 96,947 & 95,663 & 94,370 & 93,068 & 91,757 & 90,435 & 89,102 & 87,756 & 86,397 & 85,024 & 83,636 & 82,231 & 80,810 & 82,532 & 88,852 & 87,372 & 372,099 & 365,489 \\
\hline \multicolumn{22}{|l|}{\begin{tabular}{|l|} 
Total Project Returns \\
Total Project Returns: Pre-Tax
\end{tabular}} \\
\hline 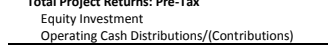 & $\begin{array}{r}-2,001,685 \\
0\end{array}$ & $\begin{array}{l}0 \\
99,493\end{array}$ & $\begin{array}{r}0 \\
98,223 \\
\end{array}$ & $\begin{aligned} 0 \\
96,947 \\
0\end{aligned}$ & $\begin{array}{r}0 \\
95,663 \\
\end{array}$ & $\begin{array}{r}0 \\
94,370\end{array}$ & $\begin{array}{r}0 \\
93,068\end{array}$ & $\begin{array}{r}0 \\
91,57\end{array}$ & $\begin{aligned} 0 \\
90,435 \\
\end{aligned}$ & $\begin{array}{r}0 \\
89,102\end{array}$ & $\begin{array}{r}0 \\
87,756\end{array}$ & $\begin{aligned} 0 \\
86,397\end{aligned}$ & $\begin{array}{r}0 \\
85,024\end{array}$ & $\begin{aligned} 0 \\
83,636\end{aligned}$ & $\begin{aligned} 0 \\
82,231\end{aligned}$ & ${ }_{80,810^{\circ}}^{\circ}$ & $\begin{array}{r}0 \\
82,532\end{array}$ & $\begin{array}{r}0 \\
88,852\end{array}$ & $\begin{array}{r}0 \\
87,372\end{array}$ & $\begin{aligned} 0 \\
372,099 \\
\end{aligned}$ & $\begin{array}{r}0 \\
365,489\end{array}$ \\
\hline $\begin{array}{l}\text { Total } \\
\text { Cumulative pre-tax lRR (\%) } \\
\text { Total Project Returs: Afte-Tax }\end{array}$ & $\begin{aligned}-2,001,685 \\
0.00\end{aligned}$ & $\begin{array}{l}99,493 \\
-95.03 \\
\end{array}$ & $\begin{array}{l}98.223 \\
-75.22\end{array}$ & $\begin{array}{l}96,947 \\
-57.17\end{array}$ & $\begin{array}{l}-95,663 \\
-43.88\end{array}$ & $\begin{array}{l}94,370 \\
-34,27 \\
\end{array}$ & $\begin{array}{l}93,068 \\
-27.21 \\
\end{array}$ & $\begin{array}{l}91,757 \\
-21.90 \\
\end{array}$ & $\begin{array}{l}\frac{9,433}{90,45} \\
-17.82\end{array}$ & $\begin{array}{l}\frac{89,102}{89,102} \\
-14.61\end{array}$ & $\begin{array}{l}\frac{81,76}{87,76} \\
-12.06\end{array}$ & $\begin{array}{l}8,39797 \\
86,3998 \\
-9.98\end{array}$ & $\begin{array}{r}3,0,24 \\
-85.24 \\
-8.28\end{array}$ & $\begin{array}{l}8,3506 \\
-6.636 \\
-6.86\end{array}$ & $\begin{array}{l}82,231 \\
-52.67 \\
-5.67\end{array}$ & $\begin{array}{l}8,0,810 \\
80.467\end{array}$ & $\begin{array}{r}62,532 \\
-3.77 \\
\end{array}$ & $\begin{array}{l}-\frac{8.852}{88,252} \\
-2.94\end{array}$ & $\begin{array}{r}87,372 \\
-2.24 \\
\end{array}$ & $\begin{array}{l}37,299 \\
372,099 \\
-0.07\end{array}$ & $\begin{array}{l}\frac{303469}{365,489} \\
1.33\end{array}$ \\
\hline $\begin{array}{l}\text { Total Project Returns: After-Tax } \\
\text { Cash } \\
\text { Equity Investment }\end{array}$ & $-2,001,685$ & 0 & 0 & 0 & 0 & 0 & & 0 & 0 & 0 & 0 & 0 & & 0 & & & & & 0 & & \\
\hline $\begin{array}{l}\text { Operating Cash Distributions/(Contributions) } \\
\text { Total }\end{array}$ & $\frac{0}{-2,001,685}$ & 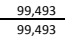 & $\begin{array}{l}98,223 \\
98,223\end{array}$ & $\begin{array}{l}96,947 \\
99,947 \\
\end{array}$ & 少5,663 95,63 & $\frac{94,370}{99,370}$ & $\frac{93,068}{99,068}$ & $\frac{91,757}{99,757}$ & $\begin{array}{l}90,435 \\
90,435\end{array}$ & $\frac{89,102}{89,102}$ & $\frac{87,756}{87,56}$ & $\frac{86,397}{88,397}$ & $\frac{85,024}{88,024}$ & $\frac{83,636}{8.3636}$ & $\frac{82,231}{88,231}$ & $\frac{80,810}{88.810}$ & $\frac{82,532}{8.532}$ & $\frac{88,852}{88.852}$ & $\frac{87,372}{87,772}$ & $\begin{array}{r}372,099 \\
372099\end{array}$ & $\frac{365,489}{365989}$ \\
\hline $\begin{array}{l}\text { Investment tax Credit } \\
\text { State } \\
\text { federal }\end{array}$ & & 0 & & & & & & & & & & & & & & & & & & & \\
\hline $\begin{array}{l}\text { Total } \\
\text { Production Tax Credit }\end{array}$ & & 0 & & & & & & & & & & & & & & & & & & & \\
\hline $\begin{array}{l}\text { state } \\
\text { Federal }\end{array}$ & $\begin{array}{c}0 \\
0 \\
0\end{array}$ & $\begin{array}{l}0 \\
0\end{array}$ & $\begin{array}{l}0 \\
0\end{array}$ & $\begin{array}{l}0 \\
0\end{array}$ & $\begin{array}{l}0 \\
0\end{array}$ & $\begin{array}{l}0 \\
0\end{array}$ & $0_{0}^{0}$ & $\begin{array}{l}0 \\
0\end{array}$ & 0 & $\begin{array}{c}0 \\
0\end{array}$ & 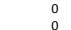 & $\begin{array}{l}0 \\
0\end{array}$ & $\stackrel{0}{0}$ & $: 0$ & 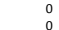 & $\begin{array}{l}0 \\
0\end{array}$ & $0_{0}^{0}$ & $\begin{array}{l}0 \\
0\end{array}$ & $0_{0}^{0}$ & $0_{0}^{0}$ & 0 \\
\hline $\begin{array}{l}\text { Total } \\
\text { Tonat }\end{array}$ & 0 & 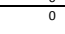 & 0 & 0 & 0 & 0 & 0 & 0 & 0 & 0 & 0 & & 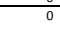 & 0 & 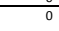 & 0 & 0 & 0 & 0 & 0 & 0 \\
\hline $\begin{array}{l}\text { State } \\
\text { Federal } \\
\text { Total } \\
\end{array}$ & $\begin{array}{l}0 \\
0 \\
0 \\
0\end{array}$ & $\begin{array}{r}0 \\
-25,910 \\
-25,910 \\
\end{array}$ & $\begin{array}{l}9,979 \\
9,979\end{array}$ & $\begin{array}{r}0 \\
9,231 \\
9,231\end{array}$ & $\begin{array}{l}0 \\
8,407 \\
8,407\end{array}$ & $\begin{array}{l}7,00 \\
7,500\end{array}$ & $\begin{array}{l}0.0 \\
6,504 \\
6,504\end{array}$ & $\begin{array}{l}0 \\
5,44 \\
5,414\end{array}$ & $\begin{array}{l}4,220 \\
4,220\end{array}$ & $\begin{array}{l}2,98 \\
2,918\end{array}$ & $\begin{array}{l}1,498 \\
1,498\end{array}$ & $\begin{array}{l}0 \\
-48 \\
-48\end{array}$ & $\begin{array}{l}0 \\
-1,838 \\
-1,838\end{array}$ & $\begin{array}{l}0 \\
-3,56 \\
-3,556\end{array}$ & $\begin{array}{l}0 \\
-5,649 \\
-5,649\end{array}$ & $\begin{aligned} 0 \\
-5,980 \\
-5,980\end{aligned}$ & $\begin{array}{r}0 \\
-38,69 \\
-3.869\end{array}$ & $\begin{aligned} 0 \\
-73,356 \\
-7.356\end{aligned}$ & $\begin{array}{r}0 \\
-76,838 \\
-7.838\end{array}$ & $\begin{aligned}-80,603 \\
-80,03\end{aligned}$ & $\begin{array}{l}-78,951 \\
-78,851\end{array}$ \\
\hline Total & $\begin{array}{l}-2,001,685 \\
\end{array}$ & $\begin{array}{ll}27,584 \\
\end{array}$ & $\begin{array}{ll}108,202 \\
\end{array}$ & $\begin{array}{ll}106,178 \\
\end{array}$ & $\begin{array}{ll}104,069 \\
\end{array}$ & $\begin{array}{ll}101,870 \\
\end{array}$ & $\begin{array}{ll}99,572 \\
\end{array}$ & $\begin{array}{ll}9,474 \\
97,170 \\
\end{array}$ & $\begin{array}{l}94,656 \\
94,656\end{array}$ & $\begin{array}{ll}92,020 \\
92,020\end{array}$ & 89,254 & 86,350 & 83,186 & $\begin{array}{l}3,30,080 \\
\end{array}$ & $\begin{aligned} 3,0458 \\
\end{aligned}$ & $\begin{array}{lll}\frac{3,300}{74,830} \\
4\end{array}$ & $\begin{array}{l}-3,0039 \\
43,864 \\
\end{array}$ & $\begin{array}{lll}15,4306 \\
\end{array}$ & $\begin{array}{ll}70,050 \\
10,534 \\
\end{array}$ & 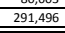 & 286,538 \\
\hline 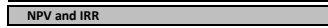 & & & & & & & & & & & & & & & & & & & & & \\
\hline $\begin{array}{l}\text { Cumulative after-tax IRR }(\%) \\
\text { Maximum } \\
\text { Year traret RR reached } \\
\text { NPV of atter- tax returns }\end{array}$ & 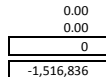 & $\begin{aligned}-96.32 \\
0.00 \\
0\end{aligned}$ & $\begin{aligned}-74.84 \\
0.00 \\
0\end{aligned}$ & $\begin{aligned}-55.25 \\
0.00 \\
0\end{aligned}$ & $\begin{array}{l}-\begin{array}{c}-42.83 \\
0.00 \\
0\end{array} \\
0\end{array}$ & $\begin{aligned}-33.24 \\
0.00 \\
0\end{aligned}$ & $\begin{array}{l}-26.26 \\
0.00 \\
0\end{array}$ & $\begin{aligned}-21.05 \\
0.00 \\
0\end{aligned}$ & $\begin{array}{l}-17.07 \\
0.00 \\
0\end{array}$ & $\begin{array}{l}-13.98 \\
0.00 \\
0\end{array}$ & $\begin{array}{c}-11.52 \\
0.00 \\
0\end{array}$ & $\begin{aligned}-9.55 \\
0.00 \\
0\end{aligned}$ & $\begin{array}{r}-7.95 \\
0.00 \\
0\end{array}$ & $\begin{aligned}-6.63 \\
0.00 \\
0\end{aligned}$ & $\begin{array}{r}-5.54 \\
0.00 \\
0\end{array}$ & $\begin{aligned} \begin{array}{r}-4.61 \\
0.00 \\
0\end{array} & 0\end{aligned}$ & $\begin{array}{r}-4.11 \\
0.00 \\
0\end{array}$ & $\begin{aligned} \begin{array}{r}-3.94 \\
0.00 \\
0\end{array} & \end{aligned}$ & $\begin{array}{l}-3.82 \\
0.00 \\
0\end{array}$ & $\begin{array}{r}-1.43 \\
0.00 \\
0\end{array}$ & $\begin{array}{c}0.06 \\
0.06 \\
0\end{array}$ \\
\hline
\end{tabular}


Appendix E: Renewable Energy Opportunities for Remote Indonesian Grids, Jakarta Workshop

Table E-1. SERIG Workshop Agenda

October 1st, 2014, Mulia Hotel

\begin{tabular}{|c|c|c|c|}
\hline Time & Duration & Activity & Presenter \\
\hline $08.30-09.00$ & $30 "$ & Registration & \\
\hline 09:00 - 09:20 & $20 "$ & Opening \& Welcoming remarks & Robert Sandoli - US DOE \\
\hline $09.20-09.35$ & $15 "$ & SERIG Program (Background) & B. Hirsch - NREL/R. Hardison - Winrock \\
\hline $09.35-9.50$ & $15 "$ & SERIG Program (Results and Opportunities) & Kari Burman - NREL \\
\hline $9.50-10.15$ & $25 "$ & Coffee break & \\
\hline \multicolumn{3}{|c|}{ Session I (Opportunities for Renewable Energies in remote Indonesian Grids) } & (Moderator) Milosz Mogilnicki \\
\hline $10.15-10.30$ & $15 "$ & USAID Energy Programs & Retno Setianingsih - USAID \\
\hline $10.30-10.45$ & $15 "$ & RE/EE Deployment Strategies to Lower Generation Cost in Isolated Grids & Anang Yahmadi - PLN \\
\hline $10.45-11.00$ & $15 "$ & Opportunities and Challenges of Smart Grid deployment & M.A.M. Oktaufik - BPPT \\
\hline $11.00-11.15$ & $15 "$ & Distributed Power Development & Rudolf Aritonang - GE Indonesia \\
\hline $11.15-11.30$ & $15 "$ & Scaling Up Renewable Energy Access in Sumba & Mike Crosetti - ADB \\
\hline $11.30-11.55$ & $25 "$ & $Q \& A$ & \\
\hline $12.00-13.00$ & $60 "$ & Lunch & \\
\hline \multicolumn{3}{|c|}{ Session II (Experience with Renewable Energy Integration Technologies) } & (Moderator) Jon Respati \\
\hline $13.00-13.15$ & $15 "$ & Electricity Storage Technologies & Greg Long - Fluidic \\
\hline $13.15-13.30$ & $15^{\prime \prime}$ & Renewables - Diesel Examples from Hawaii and Alaska & Brian Hirsch - NREL \\
\hline $13.30-13.45$ & $15^{\prime \prime}$ & Technological Advances in Integrated Isolated Grid Systems & Budi Supomo - ABB \\
\hline $13.45-14.00$ & $15^{\prime \prime}$ & Interconnecting Distributed Renewable Energy Generation Plants to PLN's Distribution System & Bill Meade - USAID-ICED \\
\hline $14.00-14.25$ & $25 "$ & Integration of Solar Technologies on Isolated Grids & N. Govindan - Sun Edison / Y. Premchand - DNV GL \\
\hline $14.25-14.50$ & $25 "$ & $Q \& A$ & \\
\hline $14.50-15.15$ & $25 "$ & Coffee break served inside the room & \\
\hline \multicolumn{3}{|c|}{ Session III (Financing Renewable Energy projects in remote areas) } & (Moderator) Rob Hardison \\
\hline $15.15-15.30$ & $15 "$ & Green Prosperity Program Funding Facility & Fred Holloway - MCA-I \\
\hline $15.30-15.45$ & $15^{\prime \prime}$ & SS - RE projects Investment from Private Sector Perspective & Suryantoro Prakoso - PT Sumberdaya Sewatama \\
\hline $15.45-16.00$ & $15^{\prime \prime}$ & Financing Challenges for Renewables in Indonesia & Darwin Trisna Djajwinata - SMI \\
\hline $16.00-16.15$ & $15 "$ & $Q \& A$ & \\
\hline $16.15-16.20$ & $5 "$ & Closing Remarks & \\
\hline
\end{tabular}


Table E-2. List of SERIG Workshop Attendees

October 1, 2014

\begin{tabular}{|c|c|c|c|c|}
\hline Name & Company/Institution & $\begin{array}{c}\text { Type of } \\
\text { business }\end{array}$ & Position & Email \\
\hline Anang Yahmadi & PT. PLN (Persero) & & & anang.yahmadi@pln.co.id \\
\hline Andrew Billard & SunEdison & $\begin{array}{l}\text { Solar project } \\
\text { developer }\end{array}$ & & Andrew.Billard@trade.gov \\
\hline Bernard Castermans & Winrock & & Country Representative & bernard@winrock-indo.org \\
\hline Bertrand Choo & $\begin{array}{l}\text { DLRE (Daily Life Renewable } \\
\text { Energy Holdings PTE.LTD) }\end{array}$ & & Business Development & bertrand.choo@dailylife.com.sg \\
\hline Bill Meade & USAID -ICED & Government & Chief of Party & Bill.Meade@tetratech.com \\
\hline Brian Hirsch & NREL & & Team leader - US & Brian.Hirsch@nrel.gov \\
\hline Budi Supomo & $A B B$ & Solar ISS \& RE & Business development & budi.supomo@id.abb.com \\
\hline Christian Fjoa & SunEdison & $\begin{array}{l}\text { Solar project } \\
\text { developer }\end{array}$ & & \\
\hline $\begin{array}{l}\text { Darwin Trisna } \\
\text { Djajawinata }\end{array}$ & $\begin{array}{l}\text { PT Sarana Multi } \\
\text { Infrastruktur }\end{array}$ & & $\begin{array}{l}\text { Direktur Pengembangan Proyek } \\
\text { \& Advisory }\end{array}$ & septina@ptsmi.co.id \\
\hline Dhiah Karsiwulan & Winrock & & & dhiah@winrock-indo.org \\
\hline $\begin{array}{l}\text { Drs. H. Sugiyarto } \\
\text { M.A.P }\end{array}$ & Lamandau district & GOVERNMENT & Wakil Bupati (Lamandau) & Ipe.Imd2013@gmail.com \\
\hline Drs. Julius Uly M.Si & Sabu District & & & sarai_pu@yahoo.com \\
\hline Fred Holloway & mca-i & & & $\begin{array}{l}\text { Frederick.holloway@mca- } \\
\text { indonesia.go.id }\end{array}$ \\
\hline Gregory Long & Fluidic Energy & Batteries & Business development & glong@fluidicenergy.com \\
\hline Ir. Lay Rohy, MT & Sabu District & Government & & sarai pu@yahoo.com \\
\hline
\end{tabular}




\begin{tabular}{|c|c|c|c|c|}
\hline Name & Company/Institution & $\begin{array}{c}\text { Type of } \\
\text { business }\end{array}$ & Position & Email \\
\hline Jon Respati & & Press & & jon.respati@surya.ac.id \\
\hline Kari Burman & NREL & Project Team & Senior Electrical Engineer & Kari.Burman@nrel.gov \\
\hline Lukita Octaviani & Winrock & Project Team & & lukita@winrock-indo.org \\
\hline M.A.M Oktaufik & BPPT & Government & & mam.oktaufik@bppt.go.id \\
\hline Millosz A. Mogilnicki & $\begin{array}{l}\text { US Treasury Office for TA } \\
\text { Infrastructure Finance Team }\end{array}$ & PLN & Resident Advisor & mmogilnicki@otateas.us \\
\hline $\begin{array}{l}\text { Naresh Kumar } \\
\text { Govindan }\end{array}$ & SunEdison & $\begin{array}{l}\text { Solar project } \\
\text { developer }\end{array}$ & Country Director- Indonesia. & nGovindan@sunedison.com \\
\hline Petrus Panaka & Winrock & Project Team & & panaka@winrock-indo.org \\
\hline Pradeep Tharakan & ADB - Jakarta & $\begin{array}{l}\text { Development } \\
\text { Bank }\end{array}$ & $\begin{array}{l}\text { Senior Climate Change } \\
\text { Specialist }\end{array}$ & ptharakan@adb.org \\
\hline Retno Setianingsih & USAID - Jakarta & Government & Energy Program Specialist & restianingsih@usaid.gov \\
\hline Rob Hardison & Winrock & Project Team & Team Leader & rob.hardison@gmail.com \\
\hline Robert Sandoli & US DOE & US Government & Director & \\
\hline Rosabelle Purnama & US Embassy Jakarta & Government & $\begin{array}{l}\text { Energy \& Natural Resources } \\
\text { Officer }\end{array}$ & PurnamaR@state.gov \\
\hline Rudolf Aritonang & GE Indonesia & \begin{tabular}{|l|} 
Energy \\
Equipment \\
provider
\end{tabular} & Strategic Project Director & made.wiratma@ge.com \\
\hline Sara L. Litke & US Embassy Jakarta & Government & $\begin{array}{l}\text { Energy \& Natural Resources } \\
\text { Officer }\end{array}$ & Litkesl@state.gov \\
\hline Suryantoro Prakoso & PT Sumberdaya Sewatama & $\begin{array}{l}\text { Diesel renting, } \\
\text { RE developer }\end{array}$ & $\begin{array}{l}\text { Chief Growth \& Strategic } \\
\text { Officer }\end{array}$ & suryantoro.prakoso@sewatama.com \\
\hline
\end{tabular}




\begin{tabular}{|c|c|c|c|c|}
\hline Name & Company/Institution & $\begin{array}{c}\text { Type of } \\
\text { business }\end{array}$ & Position & Email \\
\hline Tamara Anisa & Winrock & Project Team & & tamara@winrock-indo.org \\
\hline Tomo Hermoko & Winrock & Project Team & & tomo.hermoko@winrock-indo.org \\
\hline Yatin Premchand & DNV GL & & & Yatin.Premchand@dnvgl.com \\
\hline $\begin{array}{l}\text { Yudi Harvey A. } \\
\text { Tuwau, ST }\end{array}$ & Lamandau district & OPTIONAL & & Ipe.Imd2013@gmail.com \\
\hline $\begin{array}{l}\text { Abdul Jabir Uksim, } \\
\text { ST.MM }\end{array}$ & PINBUK & & Chairman & abdul jabir@yahoo.co.id \\
\hline Agus Arya Sutapan & B\&V International Company & & Engineer & SutapanAA@bv.com \\
\hline Alex Jayasampurna & PT. Imprima & & Marketing Manager & alex@imprima.co.id \\
\hline Andika Prastawa & BPPT & Government & $\begin{array}{l}\text { Smart Grid technologies } \\
\text { Programme Director }\end{array}$ & \\
\hline $\begin{array}{l}\text { Arief Koesoemawiria, } \\
\text { PE }\end{array}$ & SUAR INTERMUDA & & Managing Director & arief@suarintermuda.com \\
\hline Asih Kurniasari & BPPT & Government & Engineering staff & \\
\hline Astrid damayanti & $A B B$ & & $\begin{array}{l}\text { Head of Internal } \\
\text { Communications and Event } \\
\text { Management }\end{array}$ & astrid.damayanti@id.abb.com \\
\hline Barry Japadermawan & PT Imprima & RE Division & Managing Director & barry@imprima.co.id \\
\hline Bobby Gunawan & PT Pilar Wanapersada & $\begin{array}{l}\text { Palm oil } \\
\text { industry }\end{array}$ & Planning, R\&D Head & $\begin{array}{l}\text { bobby.gunawan@swagroup.co.id / } \\
\text { bobby.gunawan@dsngroup.co.id }\end{array}$ \\
\hline Budiman R Saragih & $\begin{array}{l}\text { Directorate of Bioenergy } \\
\text { EBTKE }\end{array}$ & Government & $\begin{array}{l}\text { Section Head of Analysis and } \\
\text { Evaluation Program for } \\
\text { Bioenergy }\end{array}$ & budimanlpe@yahoo.com \\
\hline Christian Tjoa & $\begin{array}{l}\text { Inti Solusi Optima/Sun } \\
\text { Edison }\end{array}$ & Solar Industry & Representative & christjoa@aim.com \\
\hline
\end{tabular}




\begin{tabular}{|c|c|c|c|c|}
\hline Name & Company/Institution & $\begin{array}{c}\text { Type of } \\
\text { business }\end{array}$ & Position & Email \\
\hline Daniel C. Tobin & US- DOE & Government & & \\
\hline Dian Novita & $\mathrm{BNI}$ & Bank & & $\begin{array}{l}\text { dian.aryanti@bni.co.id / } \\
\text { dna.dian@yahoo.com }\end{array}$ \\
\hline Dian Retno Saputro & $\mathrm{BNI}$ & Bank & Assistant Manager & dian.saputro@bni.co.id \\
\hline $\begin{array}{l}\text { Dr. Ir. Ferdi } \\
\text { Armansyah }\end{array}$ & BPPT-PTKKE & Government & Head of system engineering & ferdiarmansyah@gmail.com \\
\hline $\begin{array}{l}\text { Dr. Ir. Soni Solistia } \\
\text { Wirawan, M.Eng }\end{array}$ & WHPEGEN & Wind project & Coordinator & $\begin{array}{l}\text { soni.s.wirawan@telkom.net / } \\
\text { soni.solistia@bppt.go.id / } \\
\text { sswirawan@yahoo.com } \\
\end{array}$ \\
\hline $\begin{array}{l}\text { Dr. Ir. Unggul } \\
\text { Priyanto }\end{array}$ & BPPT & Government & Chief & $\begin{array}{l}\text { unggul.priyanto@bppt.go.id / } \\
\text { upriyanto@hotmail.com }\end{array}$ \\
\hline Edy Djuwito & Unibraw Univ & & & merdeka2@gmail.com \\
\hline Elrika Hamdi & $\begin{array}{l}\text { Frankfurt School of Finance } \\
\text { \& Management }\end{array}$ & & & elrikahamdi@gmail.com \\
\hline Endah Tjahyani & $\mathrm{BNI}$ & Bank & Manager & \\
\hline Floriann Vernaz & Green Works Asia & \begin{tabular}{|l} 
Senior \\
Associate
\end{tabular} & & \\
\hline $\begin{array}{l}\text { Getmy Terntrama } \\
\text { Siregar }\end{array}$ & $\mathrm{BNI}$ & Bank & $\begin{array}{l}\text { Manager Pemasaran \& } \\
\text { Hubungan Nasabah }\end{array}$ & getmy.siregar@bni.co.id \\
\hline Gordon Smith & CDM Smith & Consultant & & Smithgj@cdmsmith.com \\
\hline Harry Indrawan & \begin{tabular}{|l} 
Pusat Penelitian \& \\
Pengembangan \\
Ketenagalistrikan, PLN \\
\end{tabular} & $\begin{array}{l}\text { R\&D on } \\
\text { Electricity }\end{array}$ & Researcher & $\begin{array}{l}\text { harry indrawan@pln-litbang.co.id / } \\
\text { aree222@yahoo.com }\end{array}$ \\
\hline Hoai Huynh & CDM Smith & Consultant & & hoai68@gmail.com \\
\hline Ichsan & MCA-I & Donor & $\begin{array}{l}\text { manager, Project Development } \\
\text { \& Oversight }\end{array}$ & ichsan@mca-indonesia.go.id \\
\hline
\end{tabular}




\begin{tabular}{|c|c|c|c|c|}
\hline Name & Company/Institution & $\begin{array}{c}\text { Type of } \\
\text { business }\end{array}$ & Position & Email \\
\hline $\begin{array}{l}\text { Ir. Jadhie Judodiniar } \\
\text { Ardajat }\end{array}$ & Bappenas & $\begin{array}{l}\text { Direktur Energi } \\
\text { Telekomunikasi } \\
+ \text { informatika } \\
\end{array}$ & & itariady2002@yahoo.com \\
\hline $\begin{array}{l}\text { Irfan Haddy } \\
\text { Ridwanto }\end{array}$ & Tetra Tech & & Consultant & irfan phat@yahoo.com \\
\hline J.M. McGee & B\&V International Company & Energy Services & Engineering Manager & McGeeJM@bv.com \\
\hline Julie Carducci & US Embassy Jakarta & Government & Comemrcial Officer & julie.carducci@trade.gov \\
\hline Kalung Riang & US Embassy Jakarta & $\begin{array}{l}\text { Commercial } \\
\text { Specialist }\end{array}$ & & Kalung.Riang@trade.gov \\
\hline Khotimatul Fauziah & BPPT-PTKKE & Government & & \\
\hline Leonard T. Panjaitan & $\mathrm{BNI}$ & Bank & $\begin{array}{l}\text { Manager for Sustainability } \\
\text { Development }\end{array}$ & $\begin{array}{l}\text { leonard.tiopan@bni.co.id / } \\
\text { leonardpanjaitan@gmail.com }\end{array}$ \\
\hline Martha Febi C.S & PT. PEI (Pasadena) & & & marthafcs@pasadenagroup.biz \\
\hline Maura Lilis & ADB & & Energy Analyst & maura.lilis@gmail.com \\
\hline Meizawarni & $\mathrm{BNI}$ & Bank & & meizwarni20@yahoo.co.id \\
\hline Michael Crosetti & Castle Rock & & Director & mike.crosetti@castlerockasia.com \\
\hline Michael T. Hamilton & MCC US & $\begin{array}{l}\text { Donor/Govern } \\
\text { ment }\end{array}$ & $\begin{array}{l}\text { Project Management Engineer } \\
\text { Department of Compact } \\
\text { Implementation }\end{array}$ & hamiltonmt@mcc.gov \\
\hline Mike Crosetti & ADB & $\begin{array}{l}\text { Contractor } \\
\text { Support }\end{array}$ & & mike.crosetti@castlerockasia.com \\
\hline $\begin{array}{l}\text { Muhamad Zainal } \\
\text { Arifin }\end{array}$ & Sewatama & & $\begin{array}{l}\text { Market Research \& Strategy } \\
\text { Manager }\end{array}$ & muhamad.arifin@sewatama.com \\
\hline Pratyush P Prashant & MCC - US & \begin{tabular}{|l|} 
US Green \\
Prosperity \\
Program \\
\end{tabular} & $\begin{array}{l}\text { Finance and Transaction } \\
\text { advisor }\end{array}$ & pratyushprashant@hotmail.com \\
\hline
\end{tabular}




\begin{tabular}{|c|c|c|c|c|}
\hline Name & Company/Institution & $\begin{array}{c}\text { Type of } \\
\text { business }\end{array}$ & Position & Email \\
\hline Prawira Hutapea & IBCSD & & Program officer & prawira@ibcsd.or.id \\
\hline Qatro Romandhi & ESDM & Government & $\begin{array}{l}\text { Kepala Seksi Prakiraan } \\
\text { Kebutuhan Energi Direktorat } \\
\text { Konservasi Energi }\end{array}$ & q romandhi@yahoo.com \\
\hline Ramsey Dame & $\mathrm{BNI}$ & & Credit Business Corporate & $\begin{array}{l}\text { ramsey.dame@bni.co.id / } \\
\text { ramsey dame@yahoo.com }\end{array}$ \\
\hline $\begin{array}{l}\text { Ratna Ayu } \\
\text { Kusumaningtyas }\end{array}$ & EBTKE (MEMR) & & Staff of Environment Section & ratnayukusumaningtyas@gmail.com \\
\hline $\begin{array}{l}\text { Rene Treumer } \\
\text { Andersen }\end{array}$ & ESP3 - DANIDA & $\begin{array}{l}\text { DANIDA donor } \\
\text { program }\end{array}$ & Technical Advisor & rene67andersen@hotmail.com \\
\hline Rina Irawati, ST, M.T & P3TKEBTKG & & Peneliti & \\
\hline Stefanus Edy Syarkim & B\&W International Company & & General Manager & sesyarkim@babcock.com \\
\hline Steven Morton & $A B B$ & & $\begin{array}{l}\text { Senior Financial Advisor Export } \\
\text { Finance }\end{array}$ & steve.morton@ch.abb.com \\
\hline Suryo Busono & BPPT & & Senior Renewable Researcher & $\begin{array}{l}\text { suryo.busono@bppt.go.id / } \\
\text { busono.suryo@yahoo.com }\end{array}$ \\
\hline \begin{tabular}{|l} 
Unggung \\
Widhiantoro
\end{tabular} & ESP3 Danida & & Programme Officer & uwidhiantoto@esp3.org \\
\hline Yanssen Tandy & PT. Nasindo & & & \\
\hline Yuli Astriani & BPPT-PTKKE & & & \\
\hline Yung Yih Tan & DLRE & & Director, Special Projects & yy.tan@dailylife.com.sg \\
\hline
\end{tabular}




\section{Appendix F: International Donor Organization in Indonesia}

\begin{tabular}{|c|c|c|c|c|}
\hline Organization & Project & Duration & Budget & Relevant Activities \\
\hline \multirow[t]{2}{*}{$\begin{array}{l}\text { US Agency for } \\
\text { International } \\
\text { Development }\end{array}$} & $\begin{array}{l}\text { Capacity for } \\
\text { Indonesian } \\
\text { Reduction of } \\
\text { Carbon in Land Use } \\
\text { and Energy } \\
\text { (CIRCLE) }\end{array}$ & $\begin{array}{l}11 / 2011- \\
03 / 2014\end{array}$ & $\begin{array}{l}\text { USD } 1.5 \\
\text { million }\end{array}$ & $\begin{array}{l}\text { Providing technical } \\
\text { capacity for sustainable } \\
\text { palm oil mills. }\end{array}$ \\
\hline & $\begin{array}{l}\text { USAID, Indonesia } \\
\text { Clean Energy } \\
\text { Development } \\
\text { (ICED) }\end{array}$ & $\begin{array}{l}03 / 2011- \\
09 / 2014\end{array}$ & $\begin{array}{l}\text { USD } \\
16.2 \\
\text { million }\end{array}$ & $\begin{array}{l}\text { Working Increase access } \\
\text { to energy services to } \\
\text { stimulate economic } \\
\text { growth and reduce GHG } \\
\text { emission from the energy } \\
\text { sector through: Improved } \\
\text { policy reform, } \\
\text { coordination and } \\
\text { implementation. }\end{array}$ \\
\hline $\begin{array}{l}\text { Ministry for } \\
\text { Foreign Affairs } \\
\text { of Finland }\end{array}$ & $\begin{array}{l}\text { Energy and } \\
\text { Environmental } \\
\text { Partnership with } \\
\text { Indonesia (EEP } \\
\text { Indonesia) } \\
\end{array}$ & $\begin{array}{l}2011 / 201 \\
3\end{array}$ & $\begin{array}{l}\text { USD } 5.3 \\
\text { million }\end{array}$ & $\begin{array}{l}\text { Promote and implement } \\
\text { bioenergy energy in Riau } \\
\text { and Central Kalimantan } \\
\text { provinces. }\end{array}$ \\
\hline \multirow[t]{2}{*}{$\begin{array}{l}\text { United Nations } \\
\text { Development } \\
\text { Program }\end{array}$} & $\begin{array}{l}\text { Wind Hybrid } \\
\text { Power Generation } \\
\text { (WHyPGen) } \\
\text { Market } \\
\text { Development } \\
\text { Initiatives } \\
\end{array}$ & $\begin{array}{l}06 / 2012 \\
- \\
06 / 2015\end{array}$ & $\begin{array}{l}\text { USD } 2.1 \\
\text { million }\end{array}$ & $\begin{array}{l}\text { Support development and } \\
\text { commercialization of } \\
\text { wind energy. }\end{array}$ \\
\hline & $\begin{array}{l}\text { Barrier Removal to } \\
\text { the cost effective } \\
\text { development and } \\
\text { implementation of } \\
\text { Energy Efficiency } \\
\text { Standards and } \\
\text { Labeling (BRESL) } \\
\text { project }\end{array}$ & $\begin{array}{l}2009- \\
2014\end{array}$ & $\begin{array}{l}\text { USD } 4 \\
\text { million }\end{array}$ & $\begin{array}{l}\text { Working to remove } \\
\text { barriers in implementing } \\
\text { energy standards and } \\
\text { labeling (ES\&L) in } \\
\text { Indonesia. }\end{array}$ \\
\hline $\begin{array}{l}\text { US Department } \\
\text { of Energy }\end{array}$ & $\begin{array}{l}\text { Sustainable Energy } \\
\text { for Remote Grids } \\
\text { (SERIG) }\end{array}$ & $\begin{array}{l}05 / 2013- \\
6 / 2015\end{array}$ & $\begin{array}{l}\text { USD } 1.2 \\
\text { million }\end{array}$ & $\begin{array}{l}\text { Facilitating integration of } \\
\text { RE and EE solutions for } \\
\text { remote grids. }\end{array}$ \\
\hline $\begin{array}{l}\text { Asia } \\
\text { Development } \\
\text { Bank }\end{array}$ & $\begin{array}{l}\text { Scaling Up } \\
\text { Renewable Energy } \\
\text { Access in Eastern } \\
\text { Indonesia. }\end{array}$ & $\begin{array}{l}\text { June } \\
2013 / \text { Jun } \\
\text { e } 2015 \text {. }\end{array}$ & $\begin{array}{l}\text { USD } 1 \\
\text { million }\end{array}$ & $\begin{array}{l}\text { Working to increase the } \\
\text { development of clean } \\
\text { energy projects on } \\
\text { Sumba Island. }\end{array}$ \\
\hline
\end{tabular}




\begin{tabular}{|c|c|c|c|c|}
\hline Organization & Project & Duration & Budget & Relevant Activities \\
\hline $\begin{array}{l}\text { Ministry of } \\
\text { Foreign Affairs } \\
\text { of Denmark } \\
\text { (DANIDA) }\end{array}$ & $\begin{array}{l}\text { Environmental } \\
\text { Support Program II }\end{array}$ & $\begin{array}{l}11 / 2008- \\
12 / 2012\end{array}$ & $\begin{array}{l}\text { USD } 9.4 \\
\text { million }\end{array}$ & $\begin{array}{l}\text { Promote Energy } \\
\text { Efficiency and } \\
\text { Conservation in } \\
\text { Industrial, Commercial } \\
\text { and Public Sector } \\
\text { through capacity building } \\
\text { and awareness. }\end{array}$ \\
\hline $\begin{array}{l}\text { United Nations } \\
\text { Industrial } \\
\text { Development } \\
\text { Organization } \\
\text { (UNIDO) - } \\
\text { Global } \\
\text { Environment } \\
\text { Facility, } \\
\text { MEMR, } \\
\text { Ministry of } \\
\text { Industry and } \\
\text { National } \\
\text { Standard } \\
\text { Agency (BSN). }\end{array}$ & $\begin{array}{l}\text { Promoting Energy } \\
\text { Efficiency in the } \\
\text { Industries through } \\
\text { System } \\
\text { Optimization and } \\
\text { Energy } \\
\text { Management } \\
\text { System Standards } \\
\text { in Indonesia. }\end{array}$ & $\begin{array}{l}2012- \\
2017\end{array}$ & $\begin{array}{l}\text { USD } 16 \\
\text { million }\end{array}$ & $\begin{array}{l}\text { Energy Management } \\
\text { System training to enable } \\
\text { the industry to implement } \\
\text { energy efficiency } \\
\text { measures through system } \\
\text { optimization. }\end{array}$ \\
\hline
\end{tabular}

